\title{
Stanisław Książek
}

\section{Wykształcenie kanonistyczne duchowieństwa archidiecezji gnieźnieńskiej i poznańskiej w latach 1835-1873}

Prawo Kanoniczne : kwartalnik prawno-historyczny 24/3-4, 149-223

1981

Artykuł został zdigitalizowany i opracowany do udostępnienia w internecie przez Muzeum Historii Polski w ramach prac podejmowanych na rzecz zapewnienia otwartego, powszechnego i trwałego dostępu do polskiego dorobku naukowego i kulturalnego. Artykuł jest umieszczony w kolekcji cyfrowej bazhum.muzhp.pl, gromadzącej zawartość polskich czasopism humanistycznych i społecznych.

Tekst jest udostępniony do wykorzystania w ramach dozwolonego użytku. 


\section{KS. STANISEAW KSIĄZEK}

\section{WYKSZTALCENIE KANONISTYCZNE DUCHOWIENSTWA ARCHIDIECEZJI GNIEZNIENSKIEJ I POZNANSKIEJ W LATACH 1835-1873}

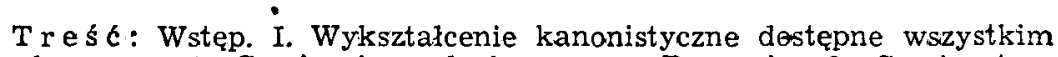
duchownym. 1. Seminarium duchawne w Poznaniu. 2. Seminarium duchowne w Gnieźnie. II. Studia kanonistyczne niektórych księży na wyższych uczelniach. 1. Studia kanonistyczne na uniwersytecie wroclawskim. 2. Studia na innych uniwersytetach niemieckich. III. Możliwości prywatnego pogłęhiania wiedzy kanonistycznej. Zakończenie.

\section{Wstęp}

Dwutomowa Polska bibliografia prawa kanonicznego od wynalezienia druku do 1940 r. O. Joachima Bara i O. Wojciecha Zmarza ukazała bogaty dorobek twórczy kanonistów polskich rekrutujących się w większości spośród duchowieństwa. Odpowiednie przygotowanie do pracy $w$ tej dziedzinie zdobywali księża $w$ seminariach duchownych i na uniwersytetach. Nauka prawa kanonicznego rozwinęla się szczególnie po wyłączeniu zagadnień kanonistycznych $z$ teologii moralnej czy historii Kościoła i stworzeniu adrębnego przedmiotu wykładowego.

Praca niniejsza należy do historii prawa kanonicznego w Polsce i obejmuje wstępne zagadnienie $z$ historii polskiej literatury kanonistycznej XIX wieku. Omawia wykształcenie kanonistyczne duchowieństwa archidiecezji gnieźnieńskiej i poznańskiej w latach 18351873. Dotyczy duchowieństwa dwóch archidiecezji, które w roku 1821 bullą De salute animarum zostaly ,aeque prinicipaliter" złączone osoba jednego arcybiskupa. Zachowały odrębne terytoria, dwa konsystorze, dwie kapituly metropolitalne i możliwość prowadzenia dwóch seminariów. Za równoczesnym omawianiem wykształcenia duchowieństwa wspomnianych archidiecezji przemawia nie tylko osoba arcybiskupa, który z racji swego urzędu zobowiązany był troszczyé się o wychowanie duchowieństwa, ale również fakt prowadzenia wspólnego seminarium teoretycznego $w$ Poznaniu i praktycznego w Gnieźnie dla obu archidiecezji. Po złączeniu archlidiecezji, do roku 1835 seminaria w Gnieźnie i Poznaniu prowadzili ksíęża misjonarze. Potem zarząd i stanowiska profesorów objęli księża diecezjalni. Działalność seminariów została przerwana $w$ okresie kulturkampfu. Minister wyznań zarządzil zamknięcie seminarium poznańskiego z dniem 23 VIII 1873 roku. Podjęto więc opracowanie wykształcenia kamonistycznego ducho- 
wieństwa archidiecezji gnieźnieńskiej i poznańskiej od momentu reorganizacji séminariów do chwili zamknięcia teoretycznego seminarium w Poznaniu.

Zagadnienie to nie zostało jeszcze dostatecznie opracowane. Mamy artyiku1 ks. Stanisława Chodyńskiego Historia prawa kanonicznego $i$ cywilnego $w$ Polsce 1 i referat ks. prof. Ignacego Grabowskiego Studium prawa kanonicznego ${ }^{2}$. W ostatnich latach ukazal się artykuł ks. prof. Tadeusza Pawluka $Z$ zagadnień kanonistyki polskiej ${ }^{3}$. Ten sam autor dal zarys rozwoju nauki prawa kanonicznego ze szczególnym uwzględnieniem Polski $\mathrm{w}$ pracy pt. Wprowadzenie do studiów kanonistycznych, Warszawa 1979. Sa to prace ciekawe i bogate w treść, ale zbyt ogólne. Najbardziej znanym dzielem $z$ tej dziedziny jest Nauka prawa kanonicznego $w$ Polsce $w$ XVIII $i$ XIX wieku, Lublin 1961, ks. prof. Aleksego Petraniego, dająca ogólny pogląd na naukę prawa kanonicznego uprawiana $w$ seminariach duchownych i na wydziałach teologicznych uniwersytetów lub akademii duchownych ${ }^{4}$. Ks. Petrani nazwał swe dzieło „przyczynkiem do ogólnej historii kultury teologicznej w Polsce” i wyraził życzenie, by inni pracownicy podjęli temat, dotychczasowe badania skorygowali i uzupelnili. Celem niniejszego artykułu nie jest skorygowanie, ale uzupełnienie $\mathrm{i}$ szersze naświetlenie tego, co w dziele ks. prof. Petraniego ujęte zostalo zaledwie na kilku stronach. Do tego czasu żaden polski ośrodek kształcenia teologicznegọ nie posiada na ten temat wyczerpującego opracowania.

W opracowaniu tego zagadnienia oparto się przede wszystkim na materiałach archiwalnych przechowywanych w Archidiecezjalnym Archiwum w Poznaniu, gdzie znajdują się akta dotyczące nie tylko archidiecezji poznańskiej, ale również archidiecezji gnieźnieńskiej, ponieważ kancelaria arcybiskupa zalatwiająca sprawy obu archidiecezji mieścila się w Poznaniu. Sięgnięto również do opracowań w języku polskim i niemieckim publikawanych $w$ XIX i XX wieku, araz do wielu czasopism. Pomogly one do stworzenia pelniejszego obrazu w tym przedmiocie.

$\mathrm{Na}$ początku omówiono wykształcenie kanonistyczne dostępne da wszystkich duchownych, które zdobywali zasadniczo w seminarium teoretycznym w Poznaniu i uzupełniali w praktycznym seminarium $w$

1 Chodyński S., Historia prawa kanonicznego $\ddot{i}$ cywilnego $w$ Polsce. W: Encyklopedia kościelna Nowodworskiego, t. 21, Warszawa 1896, s. $235-264$.

${ }^{2}$ Grabowski I., Studium prawa kanonicznego. W: Pamiętnik piątego zjazdu [Związku Zakładów Teologicznych] w Eodzi 3 IV-5 IV 1929, Kielce 1929, s. 204-222.

3 Pawluk T., Z zagadnień kanonistyki polskiej, Prawo Kan. 19/1976! nr $3-4$, s. $153-230$.

4 Jest złożone do druku dzielo zbiorowe pod redakcja O. prof. R. J. B a r a pt. Polscy kanonisci XIX $i$ XX wieku, obejmujące 470 biogramów uczonych polskich, którzy wykładali prawo kanoniczne i publikowali prace $z$ tej dziedziny. 
Gnieżnie. Jak w jednym, tak $i$ w drugim podano organizację, program nauczania prawa kanonicznego i profesorów tego przedmiotu. Studium w tych seminariach przygotowywało przede wszystkim do pracy duszpasterskiej. Ponieważ zdolniejszych kleryków po I, II lub III roku studiów $w$ seminarium poznańskim kierowano na uniwersytety, by zdobyli uprawnienia do objęcia stanowisk nauczycieli w gimnazjach i seminariach, a część maturzystów zapisywała się na Wydział Teologii bez porozumienia się $z$ wradzą duchowną $i$ po skończeniu studiów prosiła o przyjęcie do seminarium, dlatego przedmiotem drugiej części tego artykułu są studia kanonistyczne niektórych księży na wyższych uczelniach. Ostatnia, trzecia częśc artykułu poświęcona jest możliwościom prywatnego pogłębiania wiedzy kanonistycznej. Mobilizowały do tego obowiązkowe egzaminy jurysdykcyjne, egzaminy konkursowe na beneficja i konieczność obrony wolności Kościoła. Pomagaly powstające $w$ XIX wieku ośrodki kulturalno-naukowe i biJblioteki. Dużą rolę odegrały czasopisma, które kapłani czytali, redagowali i często w nich publikowali swe prace.

\section{Wyksztalcenie kanonistyczne dostępne wszystkim duchownym}

W XIX wieku na terenie Polski kandydaci do kapłaństwa zdobywali formację intelektualną i duchową w seminariach duchownych, które pod nadzorem biskupa prowadzili najczęściej księża diecezjalni. W ramach studiów trwających przeważnie trzy lata poznawali prawo kanoniczne. Początkowo zagadnienia tej dyscypliny podawano przy wykladach teologii moralnej lub historii Kościoła. Swiatlejsi biskupi dążyli do usamodzielnienia tej gałęzi wiedzy. Chociaż profesorami prawa kościelnego byli najczęściej historycy, to jednak na prawo przeznaczali osobne wykłady. Duchowieństwo archidiecezji gnieźnieńskiej i poznańskiej przygatowywało się do kapłaństwa w teoretycznym seminarium du-chownym w Poznaniu i praktycznym seminarium w Gnieźnie. Tam zdobywało wyksztalcenie kanonistyczne.

\section{Seminarium duchowne w Poznaniu}

Bulla De salute animarum pozostawiała arcybiskupowi decyzjęutworzenia dla obu archidiecezji seminarium wspólnego, ewentualnie prowadzenia dwóch oddzielnych seminariów w Gnieźnie i Poznaniu 5. Komisarz rządowy do wykonania bulli Schmedding wysunąl koncepcję utwarzenia studium filozoficzno-teologicznego w Poznaniu, a praktycznego w Gnieźnie. Dnia 7 X 1831 roku minister Altenstein $w$ piśmie do arcybiskupa Marcina Dunina wysunąl inną propozycję: stworzenia li-

$5 \mathrm{P}$ i u s VII, De salute animarum, § 24; Beiers d orf O., Papiestwo zobec sprawy polskiej $w$ latach 1772-1864, Wybór źódel, Wroclaw 1960 , s. 291. 
ceum teologicznego $w$ Poznaniu $z$ prawem nadawania stopni naukowych lub wysyłania kandydatów do kapłaństwa na uniwersytet wroclawski. Wzorem dla liceum miała być uczelnia $w$ Braniewie na Warmii ${ }^{\circ}$. Sprawa reorganizacji seminariów nie była łatwą. Została więc przekazana specjalnej komisji do spraw Wielkiego Kisiestwa Poznańskiego. Propozycje Altensteina z października i specjalnej komisji z grudnia 1831 roku nie znalazly aprobaty. Prezes Flottwell był przeciwnikiem otwarcia liceum teologicznego w Poznaniu, ponieważ $w$ studiach uniwersyteckich we Wrocławiu widział większe możliwoścı germanizacyjne Wielkopolski przez oddziaływanie mladych kapłanów kształconych $w$ środowisku pruskim ?. Natomiast arcybiskup Dunin nie chciał zgodzić się na wysylapie kleryków ani do Wrockawia, ani dc. Braniewa. Wobec takiego stanowiska minister Altenstein pozwolił urządzić czasowo studium teoretyczne w Poznaniu, licząc że po'wybudowaniu konwiktu, arcybiskup nie będzie sprzeciwial się studium nit uniwersytecie wrocławskim. Na początku 1835 roku wyjechali z seminarium poznańskiego księża misjonarze, którym w roku 1781 powierzył prowadzenie tego zakkadu biskup Antoni Onufry Okęcki. Miejsce ich zajęli księża diecezjalni, rozpoczynając od Wielkanocy 1835 roku organizowanie trzyletniego studium teoretycznego ${ }^{8}$.

Mino funkcjoncwania seminarium teoretycznego w Poznaniu i praktycznego w Gnieźnie, władze państwowe wysuwały dalsze propozycje przeniesienia studium do Wroclawia. Sprawa zostala definitywnie zakonczona, gdy arcybiskup Dunin pisrem z ủnia 17 XII 1836 roku cdpowedzia1, że bez pisma zmieniajacego postanowienia buili De salute arimarurr nie może wysyłać swoich k!eryków na studia poza granice diecezji ${ }^{9}$. Następne starania szły w kierunku przyznania seminariım poznańskiemu praw akademickich.

My̧śl założenia wyższej uczelni w Poznaniu nurtowala ludzi światJejszych już przed 1830 rokiem. Zagadnienie to interesowało nie tylko władzę duchowną, ale również wielu świeckich obywateli 10. Brak ten miało wypelnić planowane liceum teologiczne. Skoro nie doszło do stworzenia liceum, arcybiskup podjął w 1840 roku starania o przekształcenie seminarium poznańskiego na papieską akademię $z$ prawem nadawania stopni akademickich. Nastepca arcybiskupa Dunina nie szczędził w tym kierunku dalszych wysiłków, znajdując poparcie

${ }^{6} \mathrm{H}$ ozakowski W., Reorganizacja Seminarium Duch. $w$ Poznaniu. za Ks. Arcybiskupa Dunina, Aiteneum Kapł.19/1927/228.

7 F ą a M., Stan prawny Kościoła katolickiego $w$ Wielkim Księstwie Poznańskim $w$ latach 1815-1850 w świetle prawa pruskiego, Warszawa 1975 , s. $168-170$.

${ }^{8} \mathrm{Now}$ a cki J., Archidiecezja poznańska $w$ granicach historycznych. $i$ jej ustrój, Poznań 1964, s. 714.

9 H o zakowski W., Reorganizacja seminarium, s. 250.

$10 \mathrm{~J}$ a kó bczy k W., Wielkopolska w XIX wieku. W: Wybitni Wielkopolanie XIX wieku, Poznań 1959, s. 9. 
na sejmach prowincjonalnych, w poznańskiej radzie miejskiej, a nawet w sejmie pruskim ${ }^{11}$. Władze panstwowe zaledwie przejawiały skłonności powiększenia etatów profesorskich szczególnie w dziedzinie filozofii, ale pod warunkami na które nie mógl zgodzić się arcybiskup ${ }^{12}$. Starania o podniesienie seminarium poznańskiego do rangi akademii papieskiej prowadził arcybiskup Przyłuski do 1857 rołu. Główną przyczyną niepowodzenía byla antypolska polityka rządu pruskiego uprawiana $w$ szczególny sposób po wybuchu powstania w 1848 roku.

Kandydaci do kapłaństwa przynosili ze sobą nie zawsze jednolity i wystarczający stopień przygotowania. Do seminarium zgłaszali się w ciągu całego roku ${ }^{13}$, bo na początku XIX wieku nie istniało jeszczepojęcie roku szkolnego zaczynającego się równocześnie dla wszystkich uczniów. Pierwsze nauki obejmujące sztukę czytania i pisania zamożniejsi chłopcy otrzymywali od nauczycieli domawych zatrudnionych prizez rodziców, a ubożsi zdobywali podstawowe wiadomości od ludzi światlejszych. W Poznaniu jeszcze w 1826 roku uboższe wdowy organizowały prywatne nauczanie, by $w$ ten sposób zarobić na utrzymanie. Po tym przygotowaniu przechodzono do szkół miejskich. W gmachu seminarium w Poznaniu prowadzono szkołę biskupią, dla przygotowania młodzieży do kapłaństwa. Obejmowala ona klasę przygotowawczą - infimę i trzy klasy wyższe. Nie wszyscy uczyli się 4 lata. Lepiej przygotowani i zdolniejsi mogli ukończyć naukę $w$ tej szkole nawet $w$ ciągu 2 lat. Głównym przedmiotem nauczania był język laciński. Wy.chowankowie po ukończeniu szkoły biskupiej wstępowali do miejscowego seminarium, a niewielka grupa kierowala się do gimnazjum, by poświęcić się innym dyscyplinom.

Miarą wykształcenia wymaganego $\mathrm{u}$ kandydatów do seminarium był program realizowany $w$ gimnazjach, które posiadały 6 klas. Materiał niektórych klas wykładano $\mathrm{w}$ ciągu 2 lat 14 . Poszczególne klasy określano cyframi rzymskimi od I do VI. Najniższą klasą była I, a najwyższą VI. Od 1832 roiku wprowadzono nazwy łacińskie: sexta, quinta, quarta... i odwrócono porządek. Prima była od tego czasu klasą najwyższą. Po ukończeniu całego kursu gimnazjum w Prusach, za granicą lub prywatnie, składano na ręce dyrektora gimnazjum wniosek - dopuszczenie do egzaminu maturalnego. E६zaminy odbywały, się przed specjalną komisją, której przewodniczył tzv. królewski komisarz.

$11 \mathrm{~N}$ ow a cki J., Archidiecez.ja poznańska, s. 714 .

12 Archiwum Archidiecezjalne w Poznaniu (skrót: AAP), Akta Ordynariatu Arcybiskupiego w Poznaniu (skrót: OA) V 241 b; K r ot o$\mathrm{sk \textrm {i }}$ K., Krzywdy Kościoła katolickiego ze strony rzqdu pruskiego $w$ Wielkopolsce od czasu rozbiorów po r. 1848, Przegląd Powszechny $157 / 1923 / 241$.

13 Petrani A., Nauka prawa kanonicznego $w$ Polsce $w$ XVIII i XIX wieku, Lublin 1961, s. 50.

14 B rzeziński A., Żywot Xiędza Andrzeja Kidaszewskiego Regensa Seminarium duchownego $w$ Gnieźnie, Poznań 1864, s. 20-29. 
Prace pisano w klasie pod ścisłym nadzorem $\mathrm{z}$ następujących przedmiotów: języka łacińskiego, greckiego, francuskiego, matematyki, a później również z języka hebrajskiego. Nadto w Wielkim Księstwie Poznańskim Polaków obowiązywała praca $z$ języka niemieckiego, a Niemców z języka polskiego. Po pisemnym egzaminie następował ustny. Komisja zbierała się 2 razy w roku $z$ końcem każdego półrocza. Egzamin nie udany można było powtórzyć za pół roku ${ }^{15}$.

Ministerstwo Stanu dnia 31 VII 1820 roku wydało rozporządzenie gabinetowe, na mocy którego do studiów filozoficzno-teologicznych mogli być dopuszczeni ci, którzy po ukończeniu gimnazjum uzyskali świadectwo dojrzałości. Drugą możliwością przyłjęcia do seminarium był egzamin złożony wołec komisji w miejscowości, w której znajduje się naukowy zakład filozoficzno-teologiczny. Rozporządzenie ministra dotyczyło równiez seminariów w Wielkim Księstwie Poznańskim. Stworzono więc w Poznaniu komisję egzaminacyjną, do której wszedł radca konsystorski i szkolny prałat Dunin jako przewodniczący, dwóch profesorów i jeden nauczyciel królewskiego gimnazjum w Poznaniu. W egzaminie miał brać udział regens lub prefekt seminarium duchowneigo $w$ Poznaniu i jeden profesor, którzy na równi $z$ poprzednimi mieli decydować o zdatności kandydata ${ }^{16}$.

Warunki postawione przez wladze państwowe, chociaż mogły przyczynić się do podniesienia poziomu intelektualnego duchowieństwa, przyniosły jednak duże szkody przez abniżenie liczby kandydatów do kapłaństwa. Arcybiskup Gorzeński w 1825 roku wniósł petycję do rządu - o zmianę wymogów uskarżając się, że w ciagu dwóch lat nie mógł być przyjęty do seminarium żaden kandydat ${ }^{17}$. Minister wyznań przychylając się do prośby ustalił, aby od kandydatów do seminarium $w$ Gnieźnie i Poznaniu żądano znajomości języka polśkiego i lacińskiego $w$ zakresie quinty, a $\mathrm{z}$ pozostałych przedmiotów wykładanych $\mathrm{w}$ gimnazjum $w$ zakresie quarty. Zarządzenie traciło moc po 5 latach, jednak na prośbę arcybiskupa Wolickiego i Dunina przedłużano jego ważność na następne lata ${ }^{18}$.

Chociaż w późniejszych latach przyjmowano do seminarium młodzieńców po egzaminie maturalnym, nie byli jednak naleźycie przygotowani do studiów. Gimnazja dawały łatwość korzystania za źródel i literatury w językach klasycznych, ale nie rozwijały samodzielności myślenia i osądzania zjawisk. Zamilowany filolog klasyczny, nauczyciel i autor rozprawy $O$ zasadach wychowania po szkotach wyżsych, opublikowanej na lamach Orędownika Naukowego w 1840 roku, widzial

${ }^{15} \mathrm{~S}$ toiński J., Szkolnictwo srednie $w$ Wielkim Księstwie Poznańskim $w$ I potowie XIX wieku (1815-1850), Poznań 1972. s. 48, 65.

16 Amtsblatt der Königlichen Preussischen Regierung zu Posen (skrót ARP) $26 / 1823 / 304-306$.

${ }^{17} \mathrm{~F}$ a k a M., Stan prawny Kościoła, s. 163.

18 ARP $39 / 1831 / 451$. 
szkodliwą przewagę i błędną metode nauczania języków starożytnych. Stwierdzał, ze ,uczniowie po dziewięcioletnim wychowaniu... wychodzą na świat próżni wszelkich wiadomości historycznych, geograficznych, przyrodniczych, religijnych, filozoficznych... stąd niezręczność... w pożyciu, ... niedojrzałość w rozumowaniu o rzeczach, słowem nagość serca i rozumu..."19. Z takim stanem przygotowania musiały się liczyć osoby odpowiedzialne za intelektualne i moralne przygotowanie kandydatów do kapłaństwa. Szczególnie zainteresowani tym byli arcybiskupi, prowizorzy, rektorzy i grono profesorskie. Musieli układać zajęcia tak, by braki usunąć, dać odpowiedni zasób wiedzy i przekazać właściwą formację duchową.

$\mathrm{W}$ pierwszych miesiącach po otwarciu teoretycznego seminarium $\mathrm{w}$ Poznaniu moc obowiązującą posiadała ordynacja biskupa Okęckiego z dnia 15 IX 1784 roku, ze zmianami dokonanymi w późniejszym czasie. Ponieważ arcybiskup Dunin nie dopuszczał myśli o tymiczasowości seminarium w Poznaniu i pragnął oprzeć jego funikcjonowanie na trwałych zasadach, zająl się wkrótce przygotowaniem nowego regulaminu. Już w listopadzie 1835 roku przedłożył ks. kanonikowi Jabczyńskiemu araz profesorom tymczasowy własnoręcznie napisany statut, który nakazal odczytać alumnom w obydwu językach i dopilnować jego zachowania. Upoważnił ks. Jabczyńskiego, pełniącego tymczasowo funkeje rektora, do zlożenia wniosku w sprawie ewentualny,ch popraweks ${ }^{20}$.

Dwa lata później ania 21 X 1837 roku arcylbiskup Dunin wydał Ordinatio Seminarii Posnaniensis ${ }^{21}$. W trzecim paragrafie omówił etaty profesorskie. Przewidzianych zostało czterech profesorów teologii: dogmatyki i nauk pomocniczych, teologii moralnej, historii Kościoła i prawa, egzegezy Pisma św. Otrzymali oni rangę profesorów nadzwyczajnych uniwersytetu. Języikiem wykładowym była łacina. Profesorowie mieli przeprowadzać $w$ tygodniu dziesięć prelekcji, a rektor sześć. Nie została ustalona ilość godzin dla poszczególnych przedmiotów. Arcybiskup żądał przedstawienia ogólnego prospektu studiów co trzy lata, a na początku każdego semestru zapoznawał się ze szczegółowym planem wykładów, który przygotowywal rektor w porozumieniu z gronem profesorskim. Rok akademicki rozpoczynał się 15 października, a kończył się 15 sierpnia. Podzielony był na dwa semestry. Pierwszy semestr (hibernum) trwał ad 15 października do soboty przed niedzielą palmową, a drugi (aestivum) od poniedziałku po niedzieli przewodniej do 15 sierpnia. Na końcu każdego semestru zaplanowano ustne egzaminy. Po pierwszym semestrze odbywał się egzamin w cią-

19 Grot Z., Hipolit Cegielski (1813-1868). W: Wybitni Wielkopolanie XIX wieku, Poznań 1959 , s. 195.

20 AAP, Pismo arcybiskupa Dunina do ks. Jabczyńskiego z dnia 4 XI 1835, OA IV 58.

21 AAP, Teks $t$ Ordinatio Seminarii Posnaniensis, Akta Seminarium Duchownego w Foznaniu (skrót: SD) 2. 
gu 4 godzin wobec grona profesorskiego, a na zakończenie roku akademickiego miał charakter bardziej uroczysty, bo trwał znacznie dhużej i brał w nim udzial arcybiskup oraz członkowie kapituly metropolitalnej. Gdy arcybiskup nie mógł przybyć na egzamin, zastępował go wikariusz generalny. Klerycy którzy odbyli trzechletni kurs teologii, składali egzamin pisemny z teologii dogmatycznej, moralnej, historii Kościoła, prawa kanonicznego i filozofii. W drugiej połowie XIX wieku doszedl jeszcze egzamin $z$ języka niemieckiego. Temat pracy pisemnej wyznaczal wykładowca danego przedmiotu. On też. czuwal nad samodzielnym opracowaniem i oceniał. Profesorowie używali dość dowolnych terminów w ocenie wiedzy zdobytej przez kleryków. Spotyka się określenia: optime, bardzo dobrze, dość dobrze, ujdzie, ledwie ujdzie, mierne wypracowanie itp. Po egzaminie pisemnym następował egzamin ustny $z$ wszystkich przedmiotów teologicznych i filozoficznych wykładanych $w$ ciagu trzech lat. Egzamin ten był warunkiem przyjęcia do seminarium praktycznego w Gnieźnie. Musieli go odbyć również ci, którzy kurs teologii kończyli na uniwersytetach. Egzamin po trzech latach studiów miał wykazać pewien stopień dojrzałości do kapłaństwa. Chociaż pisano prace z kilku przedmiotów, to tematy układali profesorowie $w$ taki sposób, by kleryk mógł wykazać zdobyte wiadomości nie tylko na wykładach danego przedmiotu. Często sam temat podsuwał myśl, by argumenty czerpać $\mathrm{z}$ teologii, historii, prawa i innych nauk. Dla przybylych $\mathrm{z}$ uniwersytetów egzamin był sprawdzianem ortodoksji. Na wielu uniwersytetach pruskich filozofię i prawo kościelne wykładali protestanci, podając naukę skażoną a nawet często zupełnie blędna. Prace pisemne opatrzone ocena i podpisem profesora danego przedmiotu, oraz protokól $z$ egzaminu ustnego włączano do akt personalnych kleryka i przekazywano do konsystorza.

Obok wymienionych czterech profesorów do przedmiotów teologicznych, zatrudniano dwóch, a nawet trzech wykładowców zwanych lektorami, którzy uczyli filozofii, teologii pasterskiej, medycyny pasterskiej, śpiewu, języka polskiego i niemieckiego ${ }^{22}$.

Pierwszy zespół profesorski rekrutował się w całości z Niemców, którzy stopniowo opuszczali. Poznań. Ich miejsca zajmowali kapłani diecezji gnieźnieńskiej i poznańskiej po zdobyciu odpowiednich kwalifikacji na uniwersytetach. Przy każdej nominacji na profesora wymagane było placet rzadu pruskiego. Pod pozorem placet usilował rząd pruski przywłaszczyć sobie prawo nominacji. W tym duchu ministerstwo przygotowało projekt i przedlożyło królowi do zatwierdzonia. Ostatecznie pozostawiono arcybiskupowi prawo nominowania profesorów teologii, a ministrowi wyznań zastrzeżono mianowanie profesorów filozofii.

22 Por. Index Scholarum in Seminario Archidioecesano... instituendarum 1841-1847; AAP, Index lectionum, SD 10, 11, 12. 
Statut biskupa Okęckiego wśród dyscyplin teologicznych, ktớre polecal wykładać w seminarium, wylicza prawo kanoniczne. Może to swiadczyć. o tendencji do wyodrębnienia tego przedmiotu od innych nauk. W jezuickich szkołach polskiej prowincji już na początku XVIII wieku wykładano prawo kanonizzne jako osobny przedmiot. Misjonarze najczęściej łączyli je $z$ teologią moralną $w$ ramach której omawiano cenzury, trybunały i kongregacje rzymskie oraz proces sporny i karny. Takie ukierunkowanie posiadał używany przez mis.jonarzy podręcznilk Colleta pt. Institutiones theologiae moralis, Lugduni 1768. Misjonarze $w$ seminarium poznańskim nie wykładali prawa kanonicznego jako osobnej dyscypliny. Wiadomości z tej dziedziny podawali w sposób wystarczający przy innych przedmiotach teologicznych. Brak odpowiedniej ilości profesorów nie pozwolił im na zwiększenie liczby przedmiotów.

Zyczenie arcybiskupa Dunina skierowane do misjonarzy, by prawo kanoniczne traktowane było jako odidzielny przedmiot, urzeczywistnione zostało zaraz po objęciu zarządu seminarium przez duchowieństwo diecezjalne. Od Wielkanocy 1835 roku odbywały się prelekcje w każdy poniedzialek od godziny 15 -tej do $16-$ tej $^{23}$. W następnych semestrach zwiększono ilość wykładów. Według Ordinatio arcybiskupa Dunina nauka prawa kanonicznego miała się odbywać $w$ drugim semestrze drugiego roku studiów i w pierwszym semestrze trzeciego roku studiów. Nie została podana globalna liczba godzin, w których materiał lego przedmiotu mial być wyłożony, ani nie wskazano podręcznika według którego profesor miał prowadzić wykłady. Wzorując się na ówczesnej praktyce opartej na głównych założeniach szkoly historyczno-prawnej, przewidziano jednego profesora dla prawa kanonicznego i historii Kościola. Takie razwiązanie było szeroko stosowane w Niemczech. Ustalono liczbę zajęć dydaktycznych. Każdego profesora zabowiązano do prowadzenia dziesięciu wylkladów tygodniowo ${ }^{24}$. Sciślejsze ustalenia należały do rektora, który razem z profesorami układał szczegółowy plan na każdy semestr i od inwencji samego profesora, który zagadnienia pokrewne mógł wyczerpująco podać podczas wykładów historii Kościoła, czy innego wykładanego przez siebie przedmiatu. Gdyby prawo kanoniczne ustawić na równej płaszczyźnie $z$ historią Kościoła, wynikaloby że dla wykładów prawa kanonicznego arcybiskup wyznaczył 5 godzin $w$ tygodniu, co $\mathrm{w}$ ciągu dwóch semestrów uczyniłoby ponad 200 godzin, w których należało wyczerpać przewidziany material. Zasada stanowiąca, że prawo kanoniczne i historię Kościoła ma wykładać jeden profesor, już w chwili wydania Ordinatio nie była stosowana. Profesor Jan Franciszek Pohl obok

23 AAP, OA IV 58; Wolniewicz M., Studium Pisma świętego $w$ Arcybiskupim Seminarium Duchownym $w$ Poznaniu $w$ latach 1835-1939, Poznań 1969, s. 9.

24 AAP, Ordinatio SD 2. 
prawa kanonicznego wykladal teologię pasterską, katechetykę i pedagogike, a historii Kościoła uczył profesor Alzog. Potem historię Kościoła objął ks. Jan Janiszewski, prawo kanoniczne ks. Jan Respądek, który jakby dla uzupełnienia etatu wykładał przez pewien czas historię sztuki kościelnej. Po odejściu z seminarium rektora Janiszewskiego i profesora Ręspodka zalecenie arcybiskupa Dunina było przestrzegane. Prawo kanoniczne objęli historycy ks. Antoni Brzezinski, a potem ks. Edward Likowski. W dyskusji nad programem nauczania $w$ seminarium prowadzonej w 1856 roku ${ }^{25}$, ks. Brzeziński domagał się by zatrudniono oddzielnych profesorów dla prawa kanonicznego i historii Kościola, argumentując że ,dwie tak rozlegle dyscypliny przechódzą siły jednej osoby $\mathrm{i}$ dlatego ... $\mathrm{z}$ należyta dokładnościa. udzielane być nie mogą". Propozycja nie została przyjęta ponieważ wzorowano się na uniwersytetach pruskich.

Pierwszym profesorem prawa kanonicznego w zreorganizowanym seminarium poznańskim był ks. Adolf Cappenberg. Nominacje na to stanowisko otrzymal 13 I 1835 roku. Na podstawie reskryptu ministerialnego z dnia 19 XI 1834 roku wynagrodzenie za prace $w$ seminarium poznańskim wynosilo 400 talarów rocznie i petne utrzymanie. Posiadał tytuł profesora nadzwyczajnego ${ }^{26}$. Wykładal historię Kościoła i prawo kanoniczne. Pracowal w bardzo trudnym okresie, gdy po odejściu misjonarzy $w$ ogniu różnych zmagań ustalano nowy status tej uczelni. Arcybiskup Dunin liczył na mocniejsze związanie się Cappenberga z Poznaniem. Sugerował myśl o ewentualnym awansie $w$ dziedzinie naukowej lub $w$ hierarchii kościelnej. $Z$ nim uzgadniał arcybiskup wprowadzenie do seminarium wykładów języka polskiego w wymiarze 6 godzin tygodniowo, które mial prowadzić ks. Teodor Kiliński kanonik kolegiaty św. Marii Magdaleny w Poznaniu 27. Cappenberg pracowal w Poznaniu bardzo krótko. Przed rozpoczęciem nowego roku akademickiego 1835/36 wyjechał do Monasteru objąc stanowisko na tamtejszym uniwersytecie.

Tymczasem $z$ monasterskiego uniwersytetu przybył do Poznania na miejsce Cappenberga ks. J an A 1 z og (1808-1878). Objął wykłady historii Kościoła, prawa kanonicznego, a później egzegezy Piśma św. Wymagane kwalifikacje zdabywał na uniwersytecie we Wrocławiu, w Bonn i Monasterze, gdzie 28 II 1835 roku uzyskal doktorat teologii. Tam prowadzil prelekcje $\mathrm{z}$ historii Kościola ${ }^{28}$. Do Poznania przybył w październiku 1835 roku ${ }^{29}$. Patent na profesora historii Kościoła i

25 A.AP, List ks. Wojciechowskiego do arcybiskupa $z$ dnia 14 XI 1856, OA V 241 b.

20 AAP, Pisno areybiskupa Dunina $z$ ania 13 I 1835, OA IV 58;

Hezakowski W., Reorganizacja seminurium, s. 245 przypis.

27 AAP, Pismo arcybiskupa Dunina $z$ dnia 1 VI 1835, OA IV 58.

28 AAP, OA IV 58.

29 AAP, SD 4. 
prawa kanonicznego otrzymał dnia 16 XI 1835 roku ${ }^{30}$. Wykkady prawa kanonicznego prowadził w pierwszym semestrze roku akademickiego $1835 / 36^{31}$.

Alzog byl przede wszystkim wybitnym historykiem, który poszerzał zakres wiedzy historycznej zagadnieniami kanonistycznymi i patrystycznymi. Należy przypuszczać, że w wykładach prawa kanonicznego oprócz wiadomości, przekazywał umiłowanie Kościoła, zrozumienie jego ducha i umiarkowane pelne obiektywizmu spojrzenie na zagadnienia dyskusyjne. Taką ocenę można wydedukować na podstawie jego dzieł. Musiał również uwzględniać polskie ustawodawstwo tak w wykładach prawa kanonicznego, jak i historii Kościola, skoro ks. Jabczyński prowizor seminarium poznańskiego, podając na lamach Gazety Kościelnej notatke o odejściu Alzoga do Hildesheim, zaznaczył że „nie znał języka polskiego, ale wytrwale badał dzieje Kościola polskiego ${ }^{32}$.

Oddziaływanie Alzoga na młodzież duchowną nie ograniczało się tylko do wykładów. Razem $z$ profesorem Bittnerem wspomagali ks. Jabczyńskiego w kształtowaniu życia wewnętrznego kleryków. Na zmianę adprawiali Msze św., w których uczestniczyli wychowankowie i brali udzial w głównych medytacjach ${ }^{33}$. Dla podniesienia poziomu naukowego i zabezpieczenia możliwości pracy twórczej, pomagał Alzog w urządzaniu biblioteki seminaryjnej ${ }^{34}$.

W czasie sporu arcybiskupa Dunina $z$ rządem pruskim o zachowanie prawa kościelnego przy zawieraniu malżeństw mieszanych, ks. Alzog stanął $w$ obronie arcybiskupa. Jako dowód solidarności i uznania za mężną postawę arcybiskupa w Berlinie i Kolabrzegu, ks. Alzog ofiarował mu ukończoną $w$ tym czasie historię Kościoła ${ }^{35}$. Po dziesięciu latach pracy w Poznaniu, Alzog zostal powolany na kanonika i wicerektara seminarium diecezjalnego w Hildesheim, a potem objął katedre historii Kościola na uniwersytecie we Fryburgu Badeńskim.

W roku akademickim 1835/36 w semestrze letnim wylkłady prawa kanonicznego $w$ seminarium poznańskim objął ks. Jan Francis z e k Pohl (1803-1881). Z zachowanych wykazów zajęć wynika, że wy-

so AAP, Pismo arcybiskupa z dnia 16 XI 1835, OA IV 58; W olniew i c z M., Studium Pisma sw., s. 11 .

31 AAP, SD 4; Archiwum Teol. 1/1836/242; Petrani A., Nauta prawa kanonicznego, s. 132-133 podaje datę późniejszą o cały rok. Pohl zostal zatrudniony 16 IV 1836 roku, a więc na początku drugiego semestru w roku akademickim 1835/36. Drugi semestr (letni) roz-* poczynal się $w$ poniedziałek po niedzieli przewodniej. W wykazie zajęć w letnim semestrze zamieszczonym w "Archiwum Teologicznym" Pohl figuruje już jako profesor prawa kanonicznego.

32 Gazeta Kośc. 2/1844/396.

${ }^{33}$ AAP, List ks. Jabczyńskiego do arcybiskupa Dunina z dnia 7 XI 1835 , OA IV 58.

${ }^{34}$ W ol ni e w ic z M., Studium Pisma św., s. 11.

${ }^{35}$ Petrani A., Nauka prawa kanonicznego, s. 133. 
kłady tego przedmiotu $w$ czasie jego 10-cio letniej pracy $w$ seminarium poznańskim odbywały się od 5 do 6 godzin tygodniowo i obowiązywały kleryków drugiego roku w drugim semestrze i trzeciego roku w pierwszym semestrze. Index Scholarum in Posnaniensi Seminario Archidioecesano... podaje, że rektor Pohl w zimowym semestrze roku akademickiego 1843/44 wykładał 6 godzin tygodniowo prawo kanoniczne i 4 godziny teologie pasterską ${ }^{36}$. Zdarzały się semestry, w których ks. Pohl prowadził zajęcia tylko z prawa kanonicznego 6 godzin $w$ tygodniu, a teologię pasterska miał $\mathrm{ks}$. Urbanowicz ${ }^{37} \mathrm{lub}$ ks. Jabczyński. Ostatni prowadził wykłady w letnim semestrze roku akademickiego 1840/41 w wymiarze dwóch godzin tygodniowo podając po polsku najważniejsze zagadnienia $z$ prawa kanonicznego i tenlogii pasterskiej ${ }^{88}$.

Spisy wykładów zamieszczane $w$ indeksach i świadectwa studiów z tego czasu wyliczają tylko nazwisko profesora i wykładaną dyscyplinę. O prawie kanonicznym czyniono wzmiankę: de iuris canonici statutis - Dr Pohl. To nie pozwala na ścisłe wyodrębnienie zagadnień, które omawiano wyłącznie na wykładach prawa kanonicznego. Ponieważ ks. Pohl wykładal przedmioty potrzebne na codzień $w$ pracy duszpasterskiej, stąd można przypuszczać, że materiał z prawa kanonicznego podawał praktycznie ${ }^{89}$. To było wystarczające, bo wiadomości historyczne o soborach, synodach i instytutach wynosili klerycy z wykladów ks. Alzoga.

Jako rektor seminarium ks. Pohl wspótpracowal ściśle z prowizorami seminarium ks. Janem Jabczyńskim i ks. dr Janem Busławem oraz ordynariuszem archidiecezji arcybiskupem Duninem. Opisal dzieje seminarium poznańskiego ${ }^{40}$, które opublikowal w Index Scholarum per menses hibernos a 1843/44 instituendarum 1843. Prace ta zamierzał ks. Jabczyński w skróceniu zamieścić w redagowanej przez siebie Gazecie Kościelnej 11. Po śmierci arcybiskupa Dunina wydał ks. Pohl rozprawę o charakterze historyczno-prawnym pt. Martin von Dunin Erzbischof von Gnesen und Posen, Marienburg 1843.

Mimo pracy $w$ archidiecezji poznańskiej, nie zrywal ks. Pohl kontaktów z macierzystą diecezją wrocławską i uniwersytetem wrocławskim. Gdy na wydziale teologii katolickiej uniwersytetu wroclawskiego zrezygnowal dobrowolnie profesor teologii pasterskiej dr Leopold Schmid, na jego miejsce powołany zostal w roku $1846 \mathrm{ks}$. Pohl i o-

s6 Gazeta Kośc. 1/1843/374.

37 AAP, Pismo ks. Pohla $z$ dnia 26 VII 1845, SD 8.

P.etra ni A., Nauka prawa kanonicznego, s. 134.

39 AAP, Personalia ks. P. Fabisza, Akta Konsystorza Generalnego w Poznaniu (skrót: KA) 220, temat na egzaminie z prawa kanonicznego w 1841 roku - Eorum qui sacris faciendis linguam vernaculam adhibendam asserunt argumenta examinentur.

40 Pohl J., Historia Seminarii Archidioecesani Posnaniensis. W: Index Scholarum per menses hibernos a. 1843/44 instituendarum, 1843. 
trzymal tytuł profesora zwyczajnego ${ }^{42}$. Po wyjeździe ks. Pohla z Poznania, pojawiła się w „Gazecie Kościelnej” notatka, że archidiecezja stracila ,ze wszech miar godnego męża" 43.

Arcybiskup Przyłuski nie miał w miejsce ks. Pohla odpowiedniego kandydata na stanowisko profesora prawa kanonicznego. Najbardziej odpowiednim wydawał się ks. Jabczyński, ale ten był przeciążony Inną pracą. Zagadnienia tego przedmiotu wykładali zastępczo profesorowie innych dyscyplin. W roku akademickim 1847/48 prawo kanoniczne wykładał 2 godziny $w$ tygodniu sam arcybiskup Przyluski, a teologię pasterską również 2 godziny w tygodniu ks. oficjał Jabczyński 44. Do prowadzenia wykkadów prawa kanonicznego arcybiskup był naleźycie przygotowany. W latach 1806 -1811 był alumnem poznańskiego seminarium duchownego, następnie wyjechał na uniwersytet we Wroclawiu, gdzie studiował na wydziale teologicznym i uzyskał doktorat teologii 45. Wypełnianie urzędu egzaminatora prosynodalnego pomagało $w$ odświeżaniu zdobytych wiadomości. Odbył podróż do Rzymu, gdzie w 1823 roku uzyskal doktorat obojga praw. Był jednym $z$ bardziej wyksztalconych duchownych $w$ tym okresie. To zapewne zadecydowało, że powierzono mu funkcje prowizora seminarium duchownego ${ }^{46}$. Wysokie stanowisko $w$ hierarchii kościelnej $i$ związane $z$ tym liczne obowiązki, nie pozwoliły na prowadzenie wykładów prawa kanonicznego przez dłuższy okres.

Działalność poznańskiego seminarium duchownego w latach 1835-1848 należy uważać jako okres wstępny, w którym powstawało i ksztaltowalo się życie naukowe tego zakładu. Prawo kanoniczne zdobyło w tym czasie właściwe miejsce wśród innych dyscyplin. Zgodnie $z$ zalożeniami, seminarium przygotowywało do pracy $w$ duszpasterstwie. Powierzanie wykładów prawa kanonicznego i teologii pasterskiej jednemu profesorowi miało duże zalety ze strony praktycznej. Wiele kwestii prawnych wyjaśniał na wykładach teologii pasterskiej nie tylko ks. Pohl, ale również ks. Urbanowicz, o którym czasopisma poznańskie mówiły, że był profesorem prawa kanonicznego ${ }^{47}$.

Najbardziej znanym w tym czasie podręcznikiem prawa kanonicznego w Prusach byla praca Ferdynanda Waltera pt. Lehrbuch des

41 Gazeta Kośc. 1/1843/374.

${ }^{42} \mathrm{Nikel}$ J., Die katholisch - theologische Fakultät. W: Festschrift zur Feier des hundertjährigen Bestehens der Universität Breslau, red. Kaufmann G., Breslau 1911, s. 128; H a s s F., Leben und Schriften der kath. theol. Dozenten, s. 87; Gazeta Kośc. 4/1846/277.

43 Gazeta Kośc. 4/1846/277.

44 Gazeta Kośc. 6/1848/13.

45 Zieliński Z., Kościót katolicki $w$ Wielkim Księsturie Poznańskim $w$ latach 1848-1865, Lublin 1973, s. 80.

${ }^{46} \mathrm{~F}$ a b is z P., De Archiepiscopatu Posnaniensi (1821-1867) commentatio historica, Oleśnica 1867, s. 37 i 77 (podaje dwie różne daty).

47 Przegląd Poznański 21/1855/102-103, przedruk z Gazety Poznańskiej.

11 - Prawo Kanoniczne 
Kirchenrechts mit Brüsksichtigung der neusten Verhältnisse, Bonn. 1822. Należy przypuszczać, że ono stanowiło główną pomoc w opracowaniu wykładów. Szczególną łatwość posługiwania się nim mieli profesorowie kształceni na uniwersytetach niemieckich. Dzielo Waltera dzieli się na 3 części. W siedmiu paragrafach pierwszej części podane są podstawowe wiadomości wprowadzające w przedmiot. Druga część zwana ogólną zawiera wykład o Kościele, historię prawa kanonicznego i naświetlenie stosunków między Kościolem a państwami w różnych częściach Niemiec. Trzecia część zwana szczegółową traktuje o wewnętrznym ustroju Kościoła, o osobach i urzędach, oraz. o zarządzie w poszczególnych częściach Kościoła (I księga). Następnie zawiera prawo rzeczowe (II księga) i omówienie służby Bożej, która zasługuje na uwagę ze strony prawa kościelnego (III księga). Dodany rejestr ułatwia korzystanie $z$ dzieła. Podręcznik Waltera dawał dostateczny zasób wiadomości tak z kościelnego prawa prywatnego, jak i z publicznego. Nie uwzględnial partykularnego prawa polskiego. Braki te uzupełniali ks. Urbanowicz, który zdobyl wỳkształcenie w Zgromadzeniu Księży Misjonarzy św. Wincentego a Paulo i. przekazywał naukę stosownie do sposobów misjonarskich, oraz ks. Jabczyński dobry znawca polskiego prawa synodalnego i historii biskupstwa poznańskiego.

Obok przekazywania wiedzy prawniczej, zwracano uwage na przygotowanie kandydatów do kaplanstwa w duchu posłuszeństwa władzy. kościelnej. Duży wplyw na wykształcenie gotowości obrony praw i wolności Kościoła miała postawa arcybiskupa Dunina $w$ sporze dotyczącym małżeństw mieszanych. Profesorowie popierali arcypasterza, a młodzież duchowna przeżywała jego uwięzienie i powrót połączony. z entuzjastycznym powitaniem. Ze Sląska przedostawały się do Wielkopolski błędne zasady głoszone przez ks. Theinera i Rongego. Nieso zamętu wprowadzil w archidiecezji poznańskiej ks. Czerski. Profesorowie podawali argumenty przeciw nauce "reformatorów", umacni’li zamiłowanie do języka łacińskiego w liturgii ${ }^{48}$ i ukazywali wartość kapłańskiego bezżenstwa.

Rok 1848 należy uważać za datę przelomową w historii studium prawa kanonicznego $w$ omawianym przez nas okresie, ponieważ zamyka okres zmieniających się często profesorów, którzy prowadząr: w seminarium wykłady $z$ innych przedmiotów, nie mogli poświęcić wiele czasu prawu kanonicznemu. Do postawienia tego przedmiotu na wysokim poziomie przyczynilo się to, że powolano na profesora ks. Jana Respądka (1817-1901) doktora obojga praw, który w

${ }^{48}$ Por. Tematy na egzaminie $\mathrm{z}$ prawa kanonicznego $\mathrm{w}$ roku 1841: I De Episcoporum electione argumentis ex historia et Theologia petitio, disputetur. II Eorum qui sacris faciendis linguam vernaculam adhibendam asserunt argumenta examinentur. AAP, Personalia ks Fabisza P., KA 220. 
latach 1848-1854 prawie wyłącznie zajmował się tą dziedziną. Studia odbył na wydziale teologicznym uniwersytetu wrocławskiego. Słuchal wykładów Baltzera, Rittera, Demma, Vetza, Moversa, Gitzlera, Ambroscha, Elvenischa i Braniussa. Po skończeniu teologii w 1843 roku rozpoczął studia na wydziale prawnym, które zakończyl w 1846 roku. $\mathrm{Na}$ obu wydziałach słuchał wytrawnego kanonisty ślaskiego prof. Gitzlera, który wykładał na wydziale teologicznym: prawo kanoniczne i kościelne, przepisy tyczące małżeństw mieszanych, oraz historię i instytuty prawa rzymskiego, a na wydziale prawnym: Pandectae, prawo spadkowe, źródła prawa rzymskiego i prawo rzymskie, oraz przepisy prawne dotyczące przysięgi. Respądek brał udzial w dwóch seminariach: u Gitzlera i Abegga, który prowadzil seminarium i zajęcia $z$ prawa karnego. W letnim semestrze 1844 roku słuchał prof. Regenbrechta, który na wydziale prawnym wykładał prawo kanoniczne i kościelne ${ }^{49}$. Studia teologiczne i prawnicze ks. Respądka na uniwersytecie wrocławskim trwały łącznie 12 semestrów.

Dla osiągnięcia stopnia doktora obojga praw udał się do Monachium, gdzie przy udziale promotora prof. Franciszka Ksawerego Zengera uzyskał dyplom 13 VIII 1847 roku. Na dysputę publiczną przygotował 15 tez. Dziesięć obejmowało zagadnienia z prawa rzymskiego i państwowego, a pięć $z$ prawa kanonicznego. Tezy z prawa kanonicznego miały następujące brzmienie: Consuetudinem ecclesiastici etiam iuris fontem esse prohibeo; Patrono simplici quem vocant, onus reparandi ecclesiam haud incubit; Patrono proprium filium ad beneficia praesentare licet; Clericorum fidejussiones validae; C. 10 de poen. et remis. (5.28) et c. $12 \mathrm{X}$ de major. et obed. (1.33) inter se non repugnant ${ }^{50}$.

Ks. Respądek w roku akademickim 1848/49, 1849/50 wykładał 9 godzin, a w następnych latach 10 godzin tygodniowo. Respektowania Ordynacji odnośnie ilości zajęć zażądal arcybiskup pismem skierowanym do prowizora ${ }^{51}$. Forma czytania wykładu $w$ takim tempie by słuchacze mogli treść zanotować, wpływała nieco hamująco na ilość przekazanego materiału. Zważywszy jednak, że prawo wykladano w ciągu calego roku akademickiego w pełnym wymiarze godzin, zasób wiedzy kanonistycznej wynoszony przez wychowanków seminarium poznańskiego był dość obszerny. Alumni na trzecim roku studiów mieli możność wysłuchać około 300 prelekcji. Od początku roku akademickiego 1850/51 obowiązek słuchania wykładów prawa kanonicznego $w$ wymiarze 3 , a nawet 4 godzin tygodniowo rozciągnięto na kurs II ${ }^{52}$. Cale studium prawa kanonicznego obejmowalo wtedy około 450 wykładów.

49 AAP, Swiadectwo studiów na uniwersytecie wrocławskim, K̇A 965.

50 AAP, Dyplom doktorski z dnia 13 VIII 1847 r., KA 965.

51 AAP, Pismo arcybiskupa do prowizora $\mathrm{z}$ dnia 17 VII 1850, SD 11.

52 AAP, SD 12. 
Oprócz tego w ciągu całego roku akademickiego 1849/50 odbyiwały się dwa razy $w$ tygodniu wykłady o celibacie, które przy udziale 23 sluchaczy studentów II i III roku ${ }^{53}$ prowadzil ks. Jan Janiszewski. Zagadnienie to należy do obowiązków stanu duchownego i bywa omawiane $\mathrm{w}$ ramach wykładów prawa kanonicznego. Odrębne wykłady poświęcone tej kwestii wprowadzono dla wroclawskich studentów teologii, a za przykładem Wrocławia poszedł Poznań. Powodem do gruntowniejszych studiów na ten temat byly odszczepieństwa Rongego i Czerskiego, które na tej płaszczyźnie podważały dyscyplinę kościelną.

Szczególowy obraz wykladanego materiału dają indeksy prelekcji zatwierdzane przez arcybiskupa. W roku akademickim 1848/49 ks. Respądek wykkadal dla III kursu Ius canonicum 6 razy $w$ tygodniu i Iurisprudentiam pastoralem 3 razy $w$ tygodniu ${ }^{54}$. Podczas zimowego semestru w roku akademickim $1849 / 50$ dla kursu III wykkadal 6 razy w tygodniu Ius canonicum i 3 razy $w$ tygodniu De beneficiis ecclesiasticis. Natomiast $w$ letnim semestrze $w$ miejsce beneficiów wyikładal De processu canonico ${ }^{55}$. Dla kursu III $\mathrm{w}$ jesiennym semestrze ro$\mathrm{ku}$ akademickiego $1850 / 51$ wykładal Ius canonicum, a dla II III kursu wspólnie De disciplina catholica in administratione sacramentorum. W letnim semestrze tegoż roku 7 godzin $w$ tygodniu wylkładał Ius canonicum et ecclesiasticum i 3 godziny De synodo dioecesana. Indeksy następnych lat podają Ius canonicum et ecclesiasticum dla kursu III, a dla kursu II i III wspólnie Institutiones antiquitatum Christianorum ${ }^{56}$ oraz De cultu divino catholico praesertim de architectura ecclesiastica et ejusdem ratione 5 .

W przygotowanie prelekcji, które czytał po polsku, wkładał ks. Respądek dużo pracy ${ }^{58}$. Zmuszony byl szukać odpowiednich terminów w języku ojczystym, by należycie oddać znaczenie wyrazów łacińskich czy niemieckich. Chociaż nie wszystkie określenia zawarte w rękopisie wykładów można dziś przyjąć bez zastrzeżeń, to jednak trzeba stwierdzić, że było to duże osiągnięcie w tamtych czasach. Terminy przyswojone na wykładach wykorzystywali kapłani w korespondencji urzędowej do wladz kościelnych i państwowych oraz $w$ twórczości kanonistycznej.

Podręcznikiem wzorcowym i podstawowym w tym okresie był Lehrbuch des Kirchenrechts aller christlichen Confessionen Ferdynanda Waltera wydany $w$ Bonn $w 1824$ roku. Z niego korzystano rówiniez $w$ Poznaniu ${ }^{59}$. Wprowadzenia $w$ przedmiot dokonal autor przez omówie-

53 AAP, SD 10.

54 AAP, SD 10.

55 AAP, SD 11.

58 AAP, SD 12

57 AAP, SD 13.

58 AAP, Rękopis wykładów ks. Respądka, MS 1419.

59 Petrani A., Nauka prawa kanonicznego, s. 135. 
nie prawa kościelnego jako takiego i prawa kościelnego jako nauti. Nasteppnie ujął materiał w 8 księgach.

Księga I Zasady ogólne (położenie prawne Kościoła katolickiego, Kościołów wschodnich i Kościoła protestanckiego, stosunek Kościoła do państwa, stosunek między wyznaniami).

Księga II Żródła prawa kościelnego (ogólny stan źródeł prawa kościelnego, historia źródeł, obowiązujące jeszcze źródla prawa kościelnego).

Księga III Ustrój Kościola (papież i jego pomocnicy, biskupi i ich pomocnicy, arcybiskupi, egzarchowie, patriarchowie i prymasi, sobory, ustrój Kościołów wschodnich, duchowna organizacja krajów protestanckich).

Księga IV Zarządzanie Kościołem (ogólnie, nauczanie, dyscyplina).

Księga V Urzędy kościelne (wychowanie kleru, święcenia, stanowiska kościelne w ogólności, obsadzanie i utrata stanowisk kościelnych).

Księga VI Majątek kościelny (historia, dobra kościelne w ogólności, tzw. fabryka Kościola).

Księga VII Życie kościelne (ceremonie kościelne w ogólności, wstąpienie do Kościoła, służba Boża, małżeństwo, śmierć chrześcijańska, szczególnie instytuty kościelne).

Księga VIII Wpływ Kościola na prawo świeckie.

$\mathrm{Na}$ końcu dzieła znajdują się dokumenty wydane w latach 1817-1830, które regulowały stosunki prawne w Bawarii, Hannowerze, w prowincji kościelnej położonej nad górnym Renem i w Prusach. Sa to bulle, edykty i brewe. Register wskazuje paragrafy zawierające poszczególne zagadnienia ${ }^{60}$.

Podręcznik Waltera był pierwszym w języku niemieckim opracowaniem prawa kościelnego ujętym $w$ duchu życzliwości do Kościoła, a równocześnie nie występującym przeciw polityce uprawianej do 1848 roku przez państwo pruskie w stosunku do Kościoła. Początkowo autor był umiarkowanym zwolennikiem gallikanizmu. Potem przy każdym nowym wydaniu podręcznika podkreślał coraz bardziej stanowczo swoje katolickie przekonania, przyjmując jak określono nie tylko stanowisko rzymskie, ale nawet kurialne ${ }^{61}$.

Ks. prof. Petrani domyśla się, że ks. Respądek posługiwal się w wykladach również dziełem pap. Benedykta XIV De synodo dioecesano ${ }^{62}$, gdzie omówiona jest organizacja symodu diecezjalnego, jegs kompentencje i sposób podejmowania uchwał. Zestawiony jest również material nadający się do omówienia na synodach diecezjalnych

on $\mathrm{W}$ a lt e r F., Lehrbuch des Kirchenrechts aller christlichen Confessionen, Bonn 1842 , wyd. 9.

o1 Schulte J., Walter $F$. W: Allgemeine Deutsche Biographie, Leipzig 1896, t. 41 , s. 24 .

-2 Petrani A., Nauka prawa kanonicznego, s. 134. 
i podane są sposoby jak uniknąć naruszenia uprawnień należących wylącznie do Stolicy Apostolskiej oraz astrzeżenia przed wprowadzaniem szkodliwych innowacji. $\mathrm{Na}$ koncu zamieszczone zostało pouczenie o roli synodów, które uprawnione są do podejmowania uchwał praeter ius commune, a nie contra, ponieważ przeciwne prawu powszechnemu lub decyzjom Stolicy Apostolskiej nie mają mocy obowiązującej. Dzielo pap. Benedykta ukazało się wtedy w nowym wydaniu i polecone było duchowieństwu przez Gazetę Kościelnq ${ }^{63}$, ale to nie wzmacnia domysłu. Raczej należy przyjąc, że ks. Respądek nawet $w$ wykładach o synodzie posługiwal się pracą Waltera, który wiele korzystał $z$ dziel Benedykta XIV ${ }^{64}$.

Ponieważ plany zajęć wyliczają pewne działy prawa kanonicznego szczegółowo, pozwala to na wyprowadzenie wniosku, że powtarzające się $w$ każdym roku wykłady określane jako ius canonicum obejmowały: zasady ogólne $\mathrm{z}$ uwzględnieniem stosunku Kościoła do panstwa, źródła prawa kościelnego, ustrój Kościoła i zarządzanie Kościołem. Znamienną rzeczą było wyodrębnianie prawa kanonicznego od prawa kościelnego. Ten podział znany był na uniwersytetach niemieckich. Przez prawo kanoniczne uważano przepisy ujęte w kanony i wydane przez Kościół, a w prawie kościelnym widziano nie tylko przepisy ujęte $w$ kanony, ale również ustawodawstwo państwowe dotyczące spraw Kościoła.

Prace abiturientów seminarium poznańskiego były często tak dobre, że mogly stanowić małe artykuły do czasopism. Z prawa kanonicznego opracowywano na egzaminie końcowym następujące tematy: 1849 r. - Czy „placetum regium” ogranicza wolność Kościola, czy nie? ${ }^{65}, 1850$ r. - O początku i prawach kapitul ${ }^{66}$, w marcu 1852 r. - Czy zwyczaj może być źródłem prawa kanonicznego i pod jakimi warunkami? ${ }^{67}$, w lipcu 1852 r. - Niezależność sądownictwa i ustawodawstwa kościelnego w rzeczach duchownych ${ }^{68}, 1853$ r. - Różnica między prawem kościelnym a kanonicznym i powaga ostatniego ${ }^{69}$.

Wyklady ks. Janiszewskiego o celibacie miały charakter prawno - historyczny. Treść ich została opublikowana w dziele pt. Bezżeństwo kaplańskie w Kościele katolickim, Gniezno 1860-1875. Praca ta została wysoko oceniona przez ówczesne czasopisma ${ }^{70}$. Autor po przedstawieniu idei kaplaństwa Chrystusowego stosownie do spełnia-

${ }^{63}$ Gazeta Kośc. 1/1843/72.

64 Walter F., Lehrbuch des Kirchenrechts aller christlichen Con. fessionen, Bonn 1843, s. VII-VIII.

65 AAP, Personalia ks. A. Wiesnera, KA 1281.

66 AAP, Personalia ks. F. Sadowskiego, KA 1006; Personalia ks. Sumińskiego, KA 1119 .

67 AAP, Personalia ks. J. Krygiera, KA 607.

68 AAP, Personalia ks. J. Poszwińskiego, KA 909.

69 AAP, Personalia ks. K. Wojciechowskiego, KA 1303.

70 Przegl. Pozn. 30/1860/328 - 335; Tygodnik Katolicki 1/1860/263-264. 
nych obowiązków nauczania, szafowania i pasterzowania omawiał idee dziewiczości i czystości u pogan, w Starym Testamencie i w Ewangelii św. Potem naświetlał źródło i początki bezżeństwa kapłańskiego, rozwój w czasach apostolskich aż do soboru w Nicei oraz przyczyny upadku moralności po soborze nicejskim, co wpłynęlo na obniżenie pojęcia o wartości celibatu. Zwracał uwage na dekrety Syrycjusza (385) i dzieje celibatu do początku wieku VI oraz ustosunkowanie się do tego zagadnienia prawodawstwa Justyniana i synodu pięcioszóstego. Ukazywał zepsucie obyczajów w Kościele zachodnim, pojedyncze usiłowania reformy i zwrot ku dobremu dzięki wysiłkom Hildebranda i Piotra Damiana. Podkreślał role Leona XI, który dal początek stalej reformie i wkład Grzegorza VIİ. Wyjaśniał trudności jakie napotykała reforma określając to zjawisko jako „bój nieprawości z reforma $w$ Mediolanie i Florencji - Arjald i Piotr Ognisty". Rozwijane przez siebie zagadnienia doprowadzal poprzez historię do soboru $w$ Trydencie, podając nie tylko fakty historyczne, ale dokładną interpretację ustaw dotyczących tego zagadnienia. $\mathrm{Na}$ tle rozwoju idei bezżeństwa w Kościele powszechnym przedstawiał jak oceniano i praktykowano celibat w Polsce, dając obraz od strony pozytywnej i negatywnej. Propagatorem negatywnego nastawienia do celibatu byl Stanisław Orzechowski.

Dzięki rzetelnej pracy dydaktycznej ks. Respądka, dobrego kierowmictwa oraz współpracy ks. rektora Janiszewskiego, czas od 1848 do 1854 roku można nazwać złotym okresem $w$ historii studium prawa kanonicznego $\mathrm{w}$ seminarium poznańskim na przestrzeni wifku XIX. Sprzyjala temu naukowa atmosfera zakładu, którą wytworzyło doBrane grono profesorów. Kapłani wykształceni $w$ tym czasie występowali stanowczo w obronie praw Kościoła, a przez publikacje na łamach czasopism wydawanych $w$ drugiej połowie XIX wieku przyczyniali się do rozwoju nauki. Biorąc pod uwage naukowe przygotowanie i wiązanie wiedzy z życiem, można uważać ks. Respądka za najlepszego profesora prawa kanonicznego $w$ poznańskim seminarium w XIX wieku. Po jego odejściu i ks. Janiszewskiego wyksztakcenie duchowieństwa $w$ dziedzinie kanonistycznej obniżyło się znacznie. Sam prof. Respądek zdobytej wiedzy nie zmarnował. Korzystał z niej w duszpasterstwie $i$ w izbie poselskiej. Słusznie ks. J. Nowacki nazwał go parlamentarzystą ${ }^{71}$.

Po odejścju ks. Respądka w 1854 roku, wykłady prawa kanonicznego objąl ks. Antoni Brzeziński (1820-1898). Studia uniwersyteckie rozpoczal na wydziale filozoficzno-teologicznym we Fryburgu Badeńskim. Po trzech semestrach przeniósł się na uniwersytet w Bonn, gdzie dnia 5 III 1845 raku uzyskał dyplom ukończenia studiów. W letnim semestrze 1844 roku słuchal wykładów prawa kościelnego, które prowadził prof. Ferdynand Walter. Zaraz po ukonczeniu stu-

${ }^{1}$ Now a cki J., Archidiecezja poznańska, s. 719. 
diów na uniwersytecie został przyjety do seminarium duchownego. Tu zdawal egzamin przewidziany dla konczących teoretyczny kurs teologii. Na pisemnym egzaminie $w$ seminarium poznańskim opracował z prawa kanonicznego 2 tematy: De eleemosynis et iuribus stolae qua? vocant i De poenis ecclesiasticis earumque exitu decretorio ${ }^{72}$.

Ks. Brzezinski początkowo wykładal prawo kanoniczne 5 godzin w tygodniu. W wykładach uczestniczyło 24 kleryków z kursu II i III 73. Podczas letniego semestru 1855 roku wykłady z zakresu prawa kanonicznego i kośeielnego odbywały się tylko 2 godziny tygodniowo ${ }^{74}$. Powodem zmniejszenia ilości wykładów mógł być stan zdrowia profesora ${ }^{75}$, który zawsze byl fizycznie slaby ${ }^{76}$. Prowadził również wykłady $z$ historii Kościoła, które przejął w 1855 roku po ks. Janiszewskim. Należy przy tym zauważyć, że wszyscy profesorowie w tym semestrze mieli mniej zajęć niż w poprzednich" semestrach. W następnych semestrach ustaliła się liczba wykładów prawa kanonicznego do trzech godzin $w$ tygodniu, przy udziale kursu II i III ${ }^{77}$. $\mathrm{Na}$ wyłożenie całego materiału tego przedmiotu wykorzystywano około 240 godzin. Obowiązującym podręcznikiem było prawo kanoniczae Waltera ${ }^{78}$ według dziewiątego wydania powiększonego i poprawionego, które ukazało się $w$ Bonn 1842 roku ${ }^{79}$.

$\mathrm{Na}$ końcowych egzaminach pisemnych opracowywali klerycy następujące tematy: $1856 \mathrm{r}$. - Wykazać, że małżeństwa mieszane są niegodziwe i czego sie wymaga, aby mogły być zawierane godziwie ${ }^{60}$, 1857 r. - Jakimi argumentami czerpanymi z prawa kanonicznego można udowodnić sentencję, że ministrami sakramentu małżeństwa są sami kontrahenci ${ }^{21}, 1862$ r. na wiosnę - Moc, skutki i możliwośt rozwiązania zaręczyn ${ }^{\mathbf{8 2}}, 1862 \mathrm{w}$ jesieni - Spór między Grzegorzem VII i Henrykiem IV ${ }^{83}, 1864$ r. - O wzajemnym związku między Kościołem i państwem ${ }^{84}$. Podobne pytania stawiał ks. Brzeziński w czasie egzaminów ustnych. Kleryk Rędziński J. omówił zagadnienie mał-

\footnotetext{
72 AAP, Personalia ks. A. Brzezińskiego, KA 112.

73 AAP, Index lectionum, SD 15.

74 A.AP, Index lectionum, SD 16.

75 Petrani A., Nauka prawa kanonicznego, s. 135.

$76 \mathrm{~J}$ a rom in H., Zarys historii kongregacji oratorium sw. Filipa Neri $w$ Polsce (1668-1968), Nasza Przeszłość 32/1970/103.

77 AAP, Index lectionum, SD 16, SD 30.

78 Petrani A., Nauka prawa kanonicznego, s. 135.

$79 \mathrm{~W}$ a lt e $\mathrm{r}$ F., Lehrbuch des Kirchenrechts aller christlichen Confessionen, Bonn 1842.

80 AAP, Personalia ks. J. Rędzińskiego, KA 872; Personalia ks. Chybickiego W., KA 103.

81 AAP, Personalia ks. Jordana A., KA 454; Personalia ks. Nitschke B.. KA 808.

82 AAP, Personalia ks. Arendta A., KA 21.

88 AAP, Personalia ks. Nizielińskiego I., KA 819; Tyg. Katol. 3/1862/394.

84 AAP, Personalia ks. Formowicza A., KA 238.
} 
żeństw mieszanych $w$ archidiecezji gnieźnieńskiej i poznańskiej ${ }^{85}$, Chybicki W. prawa honorowe patronów ${ }^{86}$, Arent A. warunki waźności małżeństwa ${ }^{87}$. Wiele pytań wymagało naświetlenia historyczno-prawnego. Tak ukierunkowane były wykłady. Ks. Brzeziński obowiązki profesora traktował bardzo poważnie. Uczyl historii Kościoła i prawa. Wydaje się, że więłrszą uwagę przykładal do historii, którą początkowo wykładał 5 godzin ${ }^{88}$, a potem 7 godzin tygodniowo ${ }^{89}$.

Od początku roku akademickiego $1865 / 66$ wykłady prawa kanonicznego objął $w$ seminarium poznańskim ks. Edward Likowski (1836-1915), który z wyjątkiem 6 miesięcy (od grudnia 1869 do czerwca 1870) prowadził zajęcia do momentu zamknięcia uczelni w 1873 roku. Studia teologiczne rozpoczal w Poznaniu, a następnie kontynuowal na akademii w Monasterze ${ }^{\mathbf{9 0}}$. Tam na podstawie egzaminów i przedstawionej rozprawy „Quid Origenes de SS. Trinitate docuerit", uzyskał 1861 roku licencjat teologii ${ }^{91}$. Promocję na doktora teologii uzyskał na akademii w Monasterze dnia $22 \mathrm{~V} 1866$ roku.

Początkowo prawo kanoniczne wykładał 3 razy $w$ tygodniu. Do udziału obowiązani byli studenci II i III kursu. $Z$ racji nacisku rządowego w kierunku usuwania języka pclskiego jako wykładowego, arcybiskup Ledóchowski polecił teologię dogmatyczną, moralną, prawo kanoniczne i hermeneutykę wykładać po łacinie. Sam związany ściśle $z$ tradycjami rzymskimi, chciał by kandydaci do kaplaństwa otrzymywali nauki w języku kościelnym. Wprowadzono poważne zmiany w ilości wykładów poszczególnych dyscyplin. Juz arcybiskup Przyluski wnosząc pewne zmiany do Ordynacji Dunina zmniejszyl o 4 godziny ilość wykładów w seminarium. Kurs I miał 33 godziny wykładów w ciągu tygodnia, kurs II 31 godzin, a kurs III 32 godziny ${ }^{92}$. Arcybiskup Ledóchowski utrzymal trzyletnie teoretyczne studia w Poznaniu i roczne studium praktyczne w Gnieźnie, ale jeszcze bardziej zmniejszył ilość godzin wykładowych dla poszczególnych przedmiotów. Wielki nacisk polożył na teologię dogmatyczna, polecając wykładac ją 9 godzin w tygodniu. Inne dyscypliny ograniczyl do 2 godzin tygodniowo. Od tej chwili prawo kanoniczne wykładano dla kursu II i III po 2 godziny $w$ tygodniu ${ }^{93}$. Cały material zmuszony był profesor ując przeciętnie w 160 wykladach. Ks.

\footnotetext{
85 AAP, Personalia ks. Rędzińskiego J., KA 872.

86 AA.P, Personalia ks. Chybickiego W., KA 103.

87 AAP, Personalia ks. Arendta A., KA 21.

$88 \mathrm{AAP}$, Index lectionum, SD 16.

${ }^{89} \mathrm{AAP}$, Index lectionum, SD 30.

90 Now a cki J., Archidiecezja poznańska, s. 122.

${ }_{91}$ G a los A., Likowsiki Edward. W: Pol. słow. biogr., t. 17, Wroclaw-Warszawa-Kraków-Grdańsk 1972, s. 330.

92 AAP, List ks. rektora Wojciechowskiego do arcybiskupa Przyłuskiego z dnia 14 XI 1856, OA V 241 b.

${ }_{93}$ AAP, Pismo arcybiskupa Ledóchowskiego w sprawie wykładów w seminarium, $\mathrm{SD} 2$.
} 
Likowski wykładał również historię Kościoła oraz zagađnienia pokrewne, które mógl przedkładać w ramach prawa kanonicznego lub historii. Aktualne przepisy prawne ujmował $w$ sposób praktyczny. W prawie małżeńskim podawał fakty i okoliczności, które alumni wyjaśniali i rozwiązywali. Odstapił od dawnego sposobu sprawdzania wiadomosici na egzaminje końcowym przez szerokie pisemne opracowanie jednej kwestii. Stawial kilka konkretnych pytań, na które egzaminowany odpowiadał pisemnie ${ }^{94}$. Przez pół roku od grudnia 1869 do 1870 roku wykładał zastepczo prawo kanoniezne i historię Kościoła w'seminarium poznańskim ks. Brzeziński według przyjętego wtedy rozkładu zajęć. Umożliwiło to ks. rektorowi Likowskiemu wyjazd do Rzymu, gdzie jako teolog towarzyszył arcybiskupowi Ledóchowskiemu na soborze watykańskim I ${ }^{95}$.

Władze pruskie wydały $11 \mathrm{~V} 1873$ roku prawa, moca których stanowiły państwowy nadzór nad seminariami duchownymi. Arcybiskup Ledóchowski nie uznal praw do ingerencji $w$ wewnętrzne sprawy zakładu, a rektor Likowski uniemożliwił kontrolę. Wskutek tego minister wyznań zarządził zamknięcie seminarium $\mathrm{z}$ dniem 23 VIII 1873 roku ${ }^{96}$. Poznań na kilka lat pozbawiony zostal uczelni duchownej, w której kandydaci do stanu duchownego zdobywali wiedzę kanonistyczną. Mała liczba kleryków kształciła się za granicą we Francji i Belgii ${ }^{97}$, a część studiowała na uniwersytetach pruskich szczególnie w, Würzburgu ${ }^{98}$.

\section{Seminarium duchowne $w$ Gnieźnie}

Od 1718 roku seminarium duchowne w Gnieźnie prowadzili Księża Misjonarze św. Wincentego a Paulo ${ }^{99}$. Bulla De salute animarum łącząc archidiecezję gnieźnieńską i poznańską aeque principaliter, pozostawiła rządcom zjednoczonych stolic decyzje prowadzenia oddzielnych seminariów dla każdej archidiecezji lub jednego wspólnego przygotowującego kandydatów do kapłaństwa dla Gniezna i Poznania 100. Sprawa kształcenia młodych kadr duchowieństwa byla przedmiotem wielu dyskusji, uzgodnień, a nawet dyplomatycznych przetargów między przedstawicielami rządu pruskiego a arcybiskupami: Gorzeńskim, Wolickim i Duninem. W wyniku stanowczej decyzji arcybiskupa Dunina i wyraźnego oświadczenia, że nie może bez zmiany postanowień bulli wysyłać kleryków na uczelnie położone na terenie obıych diecezji wla-

94 A.A.P, Personalia ks. Pyszki W., KA 933.

95 Tyg. Katol. 10/1969/723; J a r om ir H., Zarys historii kongregacji sw. Filipa, s. 104.

96 AAP, SD 50; Tyg. Katol. 14/1873/494-495.

$97 \mathrm{G}$ a los A., Likowski E., s. 330.

${ }^{98} \mathrm{~N}$ ow a cki J., Archidiecezja poznarisia, s. 123.

99 F ą k a M., Stan prawny Kościola, s. 159.

${ }^{100} \mathrm{P}$ i u s VII, De salute animarum, 824. 
dze państwowe przemilczały fakt otwarcia seminarium teoretycznego w Poznaniu i uruchomienie na początku 1835 roku seminarium praktycznego w Gnieźnie. W ten sposób trzechletnie studium przygotowujące do święceń kapłańskich przedłużono o jeden rok. Zasadnicza formacja intelektualna odbywała się odtąd przez trzy lata w Poznaniu, a w Gnieźnie klerycy mieli przygotować się ascetycznie i praktycznie w ciągu jednego roku do pracy „w Winnicy Pańskiej" ${ }^{101 .}$

Tego rodzaju zakład domagał się rektora, wicerektora, profesorów i ojca duchownego. Początkowo nie obsadzono tych stanowisk, a prowadzenie seminarium praktycznego w Gnieźnie powierzono członkom tamtejszej kapituły. Zgadzało się to ze statutami kapituły, które mówiły że zajęcie się przygotowaniem kandydatów do świeceń jest obowiązkiem kapituły. Pierwszymi opiekunami i profesorami tego zakładu byli kanonicy ks. Jan Piotr Zienkiewicz ${ }^{102}$ i ks. Walenty Grzeszkiewicz. Pomagal im wikary katedralny ks. Maciej Dorszewski ${ }^{103}$. Kanonicy zajmowali się sprawami naukowymi i duchowymi, a ks. Dorszewski sprawami materialnymi. Od 1835 roku przez 20 lat byl prokuratorem seminarium gnieźnieńskiego. W tym czasie rozbuđował gmach, a przez osuszenie i użyźnienie przyległych do seminarium łąk i bagien zwiększył jego dochody ${ }^{104}$.

Po póltora roku istnienia seminarium praktycznego $w$ Gnieźnie, dnia 3 V 1836 roku objął stanowisko pierwszy rektor ks. Jan Kanty Dąbrowski (1791-1853) ${ }^{105}$. Należał do Zgromadzenia Księży Misjonarzy św. Wincentego a Paulo. Od 1814 roku zajmowal stanowiska profesora seminarium $w$ Poznaniu i Pelplinie, skąd zostal powolany do Gniezna. Przez pewien czas pracował w duszpasterstwie. Arcybiskup Dunin darzył go wielkim zaufaniem. W 1841 roku przeniósł go na kanonikat $w$ Poznaniu i rozpocząl starania o wyniesienie go do godności biskupiej. Sakrę otrzymal dnia 20 VIII 1843 roku. Był autorem książki do nabożeństwa zwanej „Duninem”. Jako profesor, duszpasterz, rektor, a potem biskup wybitnie zasłużył się dla Kościoła.

W pracy na terenie seminarium gnieźnieńskiego wspomagał ks. Dąbrowskiego ks. A. Kidaszewski (1801-1849), który od 1837 roku zajmował stanowisko wicerektora, a potem został rektorem tego zakładu. Studiowal na uniwersytecie wrocławskim. Przebywał tu aż 12 semestrów. Po skończeniu teologii brał udział $w$ prelekcjach filozofii, pogłębjal

101 AAP, OA IV 58.

102 Ks. Zienkiewicz uzyskał doktorat teologii na uniwersytecie wroclawskim w 1822 roku na podstawie rozprawy $O$ odpustach. Była to pierwsza promocja doktorska na tym uniwersytecie. (Nikiel J., Die katholisch-theologische Fakultät, s. 101).

${ }_{103}$ Archiwum Teol. 1/1836/111-112.

${ }^{104}$ Formanowicz L., Dorszewski Maciej. W: Pol. słow. biogr. t. 5 Kraków 1939-1946, s. 345 .

10: AAG, A Sem. F 2 (Archiwum Archidiecezji Gnieźnieńskiej, Akta Seminarium); Archiwum Teol. 1/1836/243. 
filologię i z zamilowaniem zajmowal się matematyką. Przed komisja: rządową złożył dnia 13 IX 1830 roku egzamin pedagogiczny. Uzyskał uprawnienie do wykladania $w$ gimnazjum j. łacińskiego, greckiegu i historii do „secundy”, a matematyki nawet w' „prymie” ${ }^{106}$. Zabiegał o przyjęcie do seminarium w Poznaniu, ale nie zostal przyjęty. Powodem tego najprawdopodqbniej była przyjaźn, która studenta Kidaszewskiego darzył podczas studiów wrocławskich ks. prof. Theiner. Dostal się natomiast do seminarium $w$ Pelplinie i tam otrzymal święcenia dnia 4 XI 1832 roku. Prace duszpasterską w charakterze wikariusza podjąl w Chelmnie. Po aresztowaniu ks. Michała Wieruszewskiego nauczyciela religii w gimnazjum św. Marii Magdaleny upatrzono ks. Kidaszewskiego na jego następce. Biskup chełmiński Sedlag wyrazil zgodę na przejście ks. Kidaszewskiego pod jurysdykcję arcybiskupa Dunina. Dzięki znajomości z ks. Dąbrowskim, który był profesorem Kidaszewskiego w Pelplinie i walorom w kontakcie z młodzieżą, został powołany na wicerektora gnieźnieńskiego seminarium duchownego, a w latach 1841-1849 był rektorem. Ks. 'Kidaszewsiki posiada olbrzymie zasługi w dziedzinie organizacyjnej, naukowej oraz w duchowym ksztaltowaniu kleryków $\mathrm{w}$ okresie poprzedzającym święcenia kapłańskie.

Najdłużej, bo ponad 12 lat rektorem seminarium gnieźnieńskiego w omawianym tu okresie był ks. Franciszek Ksawery Duliński (18181892), który gimnazjum ukończyl w Bydgoszczy, a potem studiował na wydziale teologicznym we Wroclawiu i Bonn. $Z$ natury był bardzo porywczy, ale mimo tej wady zdobył sobie szacunek kleryków ${ }^{107}$.

Rektorzy seminarium byli zarazem profesorami teologii praktycznej. Oprócz nich zaplanowano đwóch profesorów repetentów dla teologii moralnej i prawa oraz lektora śpiewu kościelnego. Projektu ođnośnie repetentów teologii i prawa kanonicznego nie- wprowadzono zaraz w życie. Dopiero w 1854 roku powolano na repetenta teologii i prawa ks. Leopolda Lniskiego ${ }^{108}$. Całe grono profesorskie składało. się z dwóch, a najwyżej czterech osób.

Rok akademicki trwal od 15 października do 15 sierpnia. Podzielony był na dwa semestry, między którymi były dwutygodniowe ferie międzysemestralne. Pierwszy semestr trwał od 15 października do soboty przed niedzielą palmową, a drugi od poniedziałku po niedzieli przewodniej do 15 sierpnia. Tak zakreślony okres rocznych studiów praktycznych nie zawsze był przestrzegany, ponieważ nie wszyscy klerycy rozpoczynali studia w Gnieźnie równocześnie. Często skracano

106 Brzezinski A., Zywot ks. Kidaszewskiego, s. $18,20,31,51$.

107 W ojtkowski A., Duliński Franciszek Ksawery (1818-1892). W: Pol. slow. biogr. t. 5, Kraków $1939-1946$, s. 460.

108 Now a c k J., Archidiecezja poznańska, s. 714. 
drugi semestr nawet o kilka tygodni ${ }^{109}$. Decydowal o tym zasadniczo sam arcybiskup.

Kandydaci do seminarium praktycznego w Gnieźnie polecani byli przez poznańskie władze seminaryjne. Pod koniec trzeciego roku studiów teoretycznych, klerycy składali wspólnie podpisaną prośbę na ręce rektora o wyznaczenie terminu egzaminu końcowego. Datę ustalał rektor $w$ porozumieniu $z$ konsystorzem ${ }^{110}$. Kleryicy, którzy wykazali na tym egzaminie dostateczną wiedzę, mogli być przyjęci do Gniezna $z$ chwilą rozpoczecia roiku akademickiego, o ile ich zachowanie $w$ seminarium poznańskim nie budzilo zastrzeżeń. Arcybiskup Przyłuski żądał ścislej kontroli nad uczęszczaniem kleryków do kaplicy i na wykłady. Zaniedbujących obowiązki mieli przełożeni upominać, a gdy powtórna admonicja nie skutkowała, obowiązani byli odroczyć wysłanie opornego kleryka do seminarium w Gnieźnie ${ }^{111}$. Przez dlugi czas nie było innej kary na niesfornych, jak tyiko wydalenie z seminarium. Kare wydalenia stosowano bardzo rzadko z racji małej liczby kapłanów tak w jednej, jak i drugiej archidiecezji. Szerzyły się więc różna niedociągnięcia. Na wniosek rektora Janiszewskiego zatrzymano w Poznaniu 3 miesiące dłużej kleryka Wiese, ponieważ ubliżył rektorowi ${ }^{112}$.

Część kandydatów do kapłaństwa odbywała studia teologiczne na uniwers tetach. $\mathrm{Na}$ ręce rektora seminarium poznańskiego składali prośbę o przyjęcie do seminarium adresowaną do arcybiskupa, który decydował o przyjęciu i zwykle kierowal petentów na pewien czas do seminarium poznańskiego, by zapoznali się $z$ jego życiem. Niektórzy musieli zdać egzamin obowiązujący kleryków po trzech latach studiów $w$ seminarium teoretycznym ${ }^{113}$. Pobyt $w$ seminarium poznańskim nie trwał długo. Ks. Respądek zgłosił się do seminarium poznańskiego na początku roku akademickiego 1847/48, w grudniu przeszedł do Gniezna, latem 1848 roku otrzymał święcenia kaplańskie 114. Ks. Wincenty Cichowski zglosil się do seminarium w Poznaniu dnia $3 \mathrm{X}$ 1848 roku. Dzięki poparciu rektora Janiszewskiego przeszedł wkrótce do Gniezna i 24 V 1849 roku otrzymał kapłaństwo ${ }^{15}$. Ks. Józef Cybichowski do czerwca 1852 roku był w Monachium, a święcenia kaplańskie otrzymał $\mathrm{w}$ Gnieźnie już $14 \mathrm{XI}$ tego samego roku ${ }^{116}$. Pobyt jego w seminarium praktycznym ograniczyl się do kilku miesięcy. $\mathrm{Z}$ podanych przykładów widać, jak przybyłym po studiach uniwersyteckich skracano pobyt $\mathrm{w}$ seminarium praktycznym.

109 AAP, Pismo ks. Brodziszewskiego W. do arcybiskupa Dunina $z$ dnia 9 VII 1835 , OA IV 58.

110 AAP, SD 9.

111 AAP, SD 3.

$11 \mathrm{AAP}, \mathrm{SD} 9$.

113 Por. AAP, Personalia ks. A. Brzezińskiego, KA 112.

114 AAP, Personalia ks. J. Respądka, KA 965.

115 AAP, Personalia ks. W. Cichowskiego, KA 108.

116 W olniewicz M., Studium Pisma św., s. 27. 
Razem $z$ przejściem kleryka do seminarium $w$ Gnieźnie, przekazywano jego akta personalne. Teczka zawierała: podanie o przyjęcie do seminarium, własnoręcznie napisany życiorys, metrykę chrztu, potwierdzenie ogłoszenia $z$ ambony kościoła parafialnego o zamiarze wstąpienia do seminarium duchownego, świadectwo studiów i uwagi rektora dotyczące obyczajów kleryka ${ }^{117}$. Według przyjętego zwyczaju na wyższych uczelniach, świadectwo wyliczało przedmioty i nazwiska profesorów. Aby uzyskać najbardziej obiektywną i wnikliwą ocenę kleryka, arcybiskup Przyłuski polecił zaprowadzić księgę, do której uwagi odnośnie poszczególnych wychowanków mieli wpisywać co kwartal profesorowie i prokurator seminarium ${ }^{118}$. Najprawdopodobniej spostrzeżenia wpisywano przy okazji wspólnej narady pedagogicznej. Na końcu roku przedkladano arcybiskupowi rodzaj sumarycznego sprawozdania o każdym kandydacie do kapłaństwa według następującego wzoru: nazwisko, imię, data urodzenia, gdzie $i$ jak dhugo studiowal, datx przyjęcia do seminarium, znajomość języków, daty święcen, data przyjęcia do Gniezna, obyczaje $i$ kwalifikacje. Prowadzenie takich no tatek pomogło do lepszego poznania i oceny kleryka, którego przekazywano pod opiekę rektorowi praktycznego seminarium w Gnieźnie.

Arcybiskup Dunin organizując w 1835 roku seminarium praktyczne $\dot{w}$ Gnieźnie nie dał przełożonym gotowego regulaminu życia, ani programu nauczania. Polecił ułożyć tak zajęcia, „,aby alumni nie zapomnieli niczego, czego się w... seminarium teoretycznym nauczyli" ${ }^{119}$. Wykłady w pierwszych latach obejmowały homiletyke, katechetyke, liturgike i naukę pasterzowania. Wiele czasu poświęcano ćwiczeniom praktycznym. Najprawdopodobniej $z$ innych przedmiotów przełożeni zadawali klerykom pewną ilość materiału do przerobienia z książek. Stosownie do instrukcji konsystorza, w czasie przewidzianych $w$ planie ,godzin naukowych" klerycy mieli pozostawać w pokojach i, ,uczyć się jedni od drugich" ${ }^{120}$. Konsystorz gnieźnieński w lipcu 1835 roku z zadowoleniem informowal arcybiskupa Dunina, ,że klerycy w końcu $z$ uczuciem oświadczyli, że więcej $w$ tym jednym kwartale skorzy-. stali aniżeli przez cały rok $w$ seminarium poznańskim obecnie korzystać mogli" 121. Przyznać należy, że wyniki nauczania w Poznaniu w ostatnich latach przed odejściem misjonarzy spodziewających się ciągle wyjazdu, nie były zadowalające. Jednak osiągnięcia w seminarium gnieźnieńskim od Wielkanocy 1835 roku nie były aż tak kolosalne. Ocena wyszła z ust młodych ludzi, którzy rzadko doceniają war-

117 AAP, SD 12, 13.

118 AAP, Pismo arcybiskupa Przyłuskiego z dnia $1 \mathrm{~V}$ 1845, SD 3.

119 AAP, Pismo arcybiskupa Dunina $z$ dnia 3 VII 1835, OA IV 58.

120 G lemp J., Rektorzy Seminarium Duchownego $w$ Gnieźnie po

$r$. 1835, Studia Gnesnensia 2/1976/347-348.

121 AAP, Pismo ks. oficjała Brodziszewskiego do arcybiskupa Dunina $z$ dnia 9 VII 1835, OA IV 58. 
tość wiedzy teoretycznej, a zafascynowani bywają sprawami praktycznymi.

Stosownie do postanowień arcybiskupa Dunina $z$ dnia $20 \quad \mathrm{X}$ 1836 rơku ks. Dąbrowski wykładał 3 godziny tygodniowo rubryki Mszy św. i brewiarza oraz 2 godziny administracji Sakramentów św., a ks. Kidaszewski miał 7 godzin $w$ tygodniu, w tym 3 godziny teologii dogmatycznej, 2 godziny egzegezy perykop niedzielnych, 1 godzinę kaznodziejstwa i 1 godzinę katechetyki. Spowiednictwo w wymiarze 5 godzin tygodniowo prowadzil ks. Paszke ${ }^{122}$. Zagad̄nieniami z zakresu: prawa kościelnego zajmowano się o tyle, o ile łączyły się $z$ innymi przedmiotami, a najczęściej $\mathrm{z}$ teologią moralną.

Arcybiskup Przyłuski wkrótce po objęciu rządów nakazał ks. Kidaszewiskiemu opracować nowe statuty, a po zapoznaniu się $z$ projektem zalecił zmniejszyć liczbę wykładów rubryk mszału i brewiarza, a przeznaczyć więcej czasu na czytanie Soboru i powtórkę teologii dogmatycznej, moralnej i prawa. Nowe statuty wyznaczaly 5 . godzin dziennie na wykłady. Pnzed południem zalecił prowadzić wyklady od godziny 8 do 12 , a po poludniu od godziny 15 do $16^{123}$.

Trzy lata przed reorganizacją seminariów, arcybiskup Dunin po-lecil misjonarzom prowadzącym seminarium w Gnieźnie, by wykładali prawo kanoniczne jako osobny przedmiot i nakazal korzystać $z$ pracy Georga Rechbergera Enchiridion juris ecclesiastici austriaci, Lincii $1819^{124}$. Osobnych wykładów prawa kanonicznego misjonarze nie wprowadzili z racji braku profesora. Wskazany podręcznik musiał byc znany, dostępny i używany, gdy seminarium teoretycznym kierowali członkowie gnieźnieńskiej kapituly metropolitalnej. Wydawany był kilkakrotnie $w$ języku niemieckim i lacińskim. Nie posiadal jednak żadnych walorów naukowych. Zawieral prawo kościelne wydane przez cesarza Józefa II, a gdzie zabrakło przepisów państwowych, zamieszczal autor prawo kościelne zabarwiając ideą gallikanizmu 125. Austriackainstrukcja rządowa $\mathrm{z}$ dnia $25 \times 1810$ roku dotycząca studiów prawno-politycznych polecała podręcznik Rechbergera jako obowiązujący na uniwersytetach i w seminariach duchownych ${ }^{126}$. W austriackich seminariach duchownych korzystało $\mathrm{z}$ niego do polowy 1834 roku, a w seminarium gnieźnieńskim $z$ braku innych podręczników służył jeszcze przez następne lata. Zmuszala do tego konieczność, ponieważ podręcznik Pełki, którego wykładów słuchał we Wrocławiu ks. kanonik Zienkiewicz nie był $w$ tym czasie już dastępny, a podręcznik Waltera niezdobył jeszcze rozgłosu.

122 G l e m p J., Rektorzy seminarium, s. 359.

${ }^{123} \mathrm{G} 1$ e m p J., Rektorzy seminarium, s. 369 .

124 G 1 e m p J., Rektorzy seminarium, s. 345 przypis.

125 Petrani A., Nauka prawa kanonicznego, s. 68.

${ }_{126} \mathrm{~S}$ c hult e J., Rechberger Georg. W: Allg. D. Biogr. t. 27, Leipzig. 1888 , s. $497-498$. 
Ks. Kidaszewski o alumnach przybywających do Gniezna z Poznania lub $z$ uniwersytetu miál przekonanie, że przynoszą zbyt mało wiadomości potrzebnych do spełniania kapłańskiego posłannictwa. Przyczyną takiego stanu nie byli profesorowie, którzy posiadali dobre przygotowanie, ale młodzież seminaryjna nie darzyła ich zaufaniem z racji niemieckiego pochodzenia. Odczuwali to wykladowcy i chętnie przy nadarzającej się okazji wracali w ojczyste strony. Złe nastawienie niektórych kleryków do nauki, było przyczyną niedostatecznego przygotowania do egzaminów. Dla wyegzekwowania odpowiedniej wiedzy, arcybiskup Przyłuski zarządził, aby klerycy którzy na egzaminie „przepadli”, pozostawali drugi rok na tym samym kursie i jeszcze raz słuchali tych samych wylkładów ${ }^{127}$. Roczne studia w Gnieźnie były jakby ostatnią szansą uzupełnienia braków. W tym celu ks. Kidaszewski zaprowadził stare kompendia używane w klasztorach. Sam korzystał z pracy Simona Sobiecha Compendium theologiae moralis in usum confessariorum et examinandorum ${ }^{128}$, wydanym we Wroclarwiu w 1798 roku i wznawianym 1806, 1824 i 1839 roku. Autora ${ }^{129}$ znal najprawdopodobniej $\mathrm{ks}$. Kidaszewski osobiście $\mathrm{z}$ okresu studiów na uniwersytecie wroclawskim. Jako wzorzec dla seminarium praktycznego w Gnieźnie, widzial wroclawski alumnat i dlatego zaprowadził wymieniony podręcznik.

W Compendium theologiae moralis omówione zostały akty ludzkia w sposób ogólny, a potem akty dobrowolne, niedobrowolne i zagadnienie wolności. W trzecim rozdziale pierwszej części zajął się autor naturą prawa, prawem ludzkim, osobą prawodawcy, podmiotem prawa, warunkami prawa, sposobem zachowania prawa, interpretacja, epikiją, ustaniem prawa, prawem określanym terminem „irritans” i przywilejem. Zagadnieniu symonii poświęcił paragraf przy omawianiu pierwszego przykazania Bożego. W ramy siódmego przykazania ujął dominium, jego przedmiot i sposoby uzyskania dominium, oraz kontrakty ogólne, kontrakty darmowe, obciążające i testament. Część druga stanowiąca drugi tom dziela, to traktat teologiczno-prawny o sa-

127 AAP, Pismo arcybiskupa Przyłuskiego $\mathrm{z}$ dnia 20 VI 1846, SD 3.

128 Brzeziński A., Żywot ks. Kidaszewskiego, s. 113-115.

199 Ks. Szymon Sobiech ur. 8 X 1749 roku w Chróścinie koło Opola. Był uczniem szkoły jezuickiej w Opolu. Od 1765 roku studiowal filozofię i teologię na Akademil Leopoldyńskiej we Wrocławiu. W 1771 roku wstąpil do seminarium duchownego. Swięcenia kapłańskie otrzymal 1772 roku. Przez 8 lat pracowal w duszpasterstwie jako wikariusz w Powidzku, 10 lat byl ojcem duchownym w alumnacie wrockawskim i od 1790 roku do śmierci, która nastąpiła 3 III 1832 roku, pełnil obowiązki rektora alumnatu. Oprócz tego od 1795 roku był radea generalnego wikariatu, a od 1812 roku wyżsym radca konsystorskim. $\mathrm{Za}$ prace $\mathrm{w}$ dziedzinie naukowej otrzymal $w 1823$ roku tytul doktora teologii honoris causa. W roku 1830 zostal honorowym kanonikiem kapituły wrocławskiej. (R e u s ch, Sobiech Simon. W: Allg. D. Biogr. .t. 34, Leipzig 1892, s. 529 . 
kramentach. Przy kaplaństwie poświęcił autor jeden paragraf na omówienie obowiązków duchownych. Rozdział o małzeństwie podzielił na trzy artykuły: o zaręczynach i rozwiązaniu zaręczyn; o małżenstwie, przeszkodach wzbraniających i zrywających; o dyspensowaniu od przeszkód. Całe dzieło zamyka rozdział o cenzurach, gdzie po uwagach ogólnych jest wykład o ekskomunice, suspensie, interdykcie, depozycji i degradacji, o nieregularności ogólnie i szczegółowo, o nieregularności z przestępstwa i braku ${ }^{130}$. Compendium nie zawiera historii. Obejmuje wykład obowiązującego prawa. Autor nie podaje źródel i literatury. Dzielo traktuje rzeczywiście jako compendium do użytku spowiedników i pomoc w przygotowaniu do egzaminu. Posiada wiele wartościowej wiedzy i ortodoksyjne naświetlenie zagadnień. Ze względu na te ostatnie walory, zastosowanie compendium ks. Sobiecha w seminarium gnieźnieńskim było bardzo trafne.

Spośród profesorów seminarium gnieźnieńskiego nazywanych repeđentami na szczególną uwagę zasługują ze względu na swe kwalifikacje ks. Feliks Kozłowski i ks. Jan Łukowski, którzy zobowiązani byli przyswojony materiał przez kleryków w seminarium poznańskim $z$ zakresu prawa kanonicznego powtarzać i poszerzać.

Ks. Feliks Paulin Kozlowski (1803-1872) był czwartym synem Tomasza i Katarzyny z Jaszockich. Rodzice posłali go do szkoły katedralnej w Poznaniu. Po skończeniu rozpoczą naukę w gimnazjum poznańskim $z$ przerwą $w$ klasie trzeciej. W październiku 1824 roku został przyjęty do klasy IV. Ostatnie dwa lata uczęszczał do gimnazjum w Kaliszu i tam zdał maturę w 1827 roku. Zamierzal poświęcić się inżynierii i dlatego przez caly rok słuchał wykladów w szkole przygotowawczej do instytutu politechnicznego. Nie wiadomo co wpłynęlo na zmianę kierunku studiów. W maju 1828 roku uczestniczył w wykładach na wydziale prawniczym słuchając prawa cywilnego i kanonicznego. Po dwóch latach studiów gdy wybuchło powstanie, włączyl się $w$ szeregi wojskowe. Aktywnie uczestniczyl w walce jako podoficer, a potem podporucznik ${ }^{131}$. Za dzielną postawe $w$ bitwie pod Szymanowem dnia 14 VIII 1831 roku zostal przedstawiony do odznaczenia złotym krzyżem 132. Po powstaniu przez trzy semestry studiowal praws w Heidelbergu, a potem we Fryburgu Badeńskim, gdzie dnia 6 VIII 1834 roku uzyskał doktorat obojga praw. Przedstawil prace De patre apud Romanos dotem constituente et de dote ipsi restituenda, a podczas promocji odczytal rozprawę De factis et auctoritate iuris romani in Polonia. Aby przygotować się do egzaminu rządowego dla uzyska-

${ }^{130} \mathrm{~S}$ obiech $\mathrm{S}$., Compendium theologiae moralis in usum confessariorum et examinandorum, Vratislaviae 1839, wyd. 4.

${ }_{131} \mathrm{~K}$ oszutski H., Zyzuot $x$ Dr Feliksa Koztowskiego, Tyg. Katol. $13 / 1872 / 665$.

132 Brzeziński A., Mowa żałobna na pogrzebie $x$ Dr Fel. Kozlowskiego powiedziana $w$ katedrze gnieźnieñskiej dnia 18 listopada 1872 roku, Poznań 1872, s. 3.

12 - Prawo Kanoniczne 
nia stanowiska sędziego, słuchał jeszcze przez dwa semestry prawa we Fryburgu, a potem w Strassburgu, gdzie uzyskal licencjat prawa wymagany $w$ zawodzie prawniczym. Egzamin nie powiódl się mimo dwukrotnej próby. Porzucił więc ten kierunek i w październiku 1839 roku obją stanowisko aktuariusza na uniwersytecie we Fryburgu, następnie został pomocnikiem bibliotekarza, od 10 VIII 1846 roku kustoszem biblioteki uniwersyteckiej, a od 23 III 1850 roku bibliotekarzem ${ }^{138}$. Często bywał $\mathrm{w}$ domu ministra austriackiego von Wessenberga. Zaprzyjaźnił się również $z$ profesorem Staudenmeierem. Sluchał jego wykładów $z$ dogmatyki, jeździł $z$ nim do uzdrowisk i był egzekutorem jego testamentu. Klerycy i młodsi kapłani studiujący we Fryburgu doznawali wiele życzliwości od doktora Kozlowskiego ${ }^{134}$. W 45 roku życia zawarł małżeństwo, które trwało nie całe 4 lata. Zona zmarła przy porodzie 22 III 1852 roku.

$\mathrm{Na}$ początku 1860 roku dr Kozłowski skierował prośbę o przyjęcie do poznańskiege semniarium duchownego. Ponieważ nie potrzebował odbywać studiów teologicznych, po trzech miesiącach pobytu w Poznaniu i przyjęciu niższych święceń, został wysłany do Gniezna, gdzie $25 \mathrm{~V} 1861$ roku otrzymał święcenia kapłańskie. Arcybiskup mając na uwadze prawnicze studia ks. Kozłowskiego mianowal go od 12 VI 1861 roku profesorem repetentem prawa kanonicznego $w$ seminarium gnieźnieńskim, następnie został archiwariuszem konsystorza gnieźnieńskiego, egzaminatorem prosynodalnym, fiskalem arcybiskupa Ledóchowskiego, kanonikiem i obrońcą węzła małżeńskiego. Przez pracę kaplańską bardzo ściśle związał się z Gnieznem, gdzie pozostawił trwały pomnik w postaci domu dla sierot ${ }^{135}$. Fundusze na budowę zbieral mie tylko w Wielkopolsce, ale jeździl w krakowskie, do Galicji i na Górny Sląsk ${ }^{136}$. W testamencie zapisal wszystko siostrom zakonnym ${ }^{187}$. Zmarł 14 XI 1872 roku ${ }^{138}$.

Wiedzą teologiczną i prawniczą oddzialywal na kleryków i środowisko kapłańskie. Był bardzo pracowity. Jego twórczość pochodzi $z$ lat wcześniejszych, zanim wstapił do seminarium. Wiele rozpraw ogłosił w Gazecie Kościelnej, Tygodniku Katolickim (grodziskim) i Roku. Wiejskim ${ }^{139}$. Często posługiwał się pscudonimem - Paweł Lechliński ${ }^{140}$. Imię pseudonimu było jego drugim imieniem $\mathrm{z}$ chrztu, a nazwisko pochodzi od miejscowości, w której się urodzil. $Z$ dziel wydanych oddzielnieł na szczególną uwage z punktu teologiczno-prawnego

${ }^{133} \mathrm{~K}$ os zutski H., Żywot $x$ Kozlowskiego, s. 665 ns.

134 Brzeziński A., Mowa na pogrzebie $x$ Kozlowskiego, s. 4-5.

$135 \mathrm{~K}$ os zutski H., Żywot $x$ Koztowskiego, s. 668 ns.

${ }_{136}$ Brzeziński A., Mowa na pogrzebie $x$ Kozlowskiego, s. 8.

137 Tyg. Katol. 13/1872/616.

${ }^{138} \mathrm{~N}$ ow a cki J., Archidiecezja poznańska, s. 719.

139 B rzeziński A., Mowa na pogrzebie $x$ Kozlowskiego, s. 7.

140 Tyg. Katol. 13/1872/615. 
zasługuje Stosunek Kościola rzymsko-katolickiego do nowo rozpoczętych sekt Rongego i Czerskiego, Poznań 1845.

Po śmierci ks. Feliksa Kozłowskiego profesorem prawa kanonicznego w Gnieźnie zostal ks. Jan Eukow ski, ur. $15 \mathrm{~V} 1846$ roku w Ostrowie Wielkopolskim. Był synem Karola i Elżbiety $z$ domu Drydas. Rodzina jego utrzymywała się $z$ rolnictwa i ślusarstwa. Do gimnazjum uczęszczał $w$ Ostrowie Wielkopolskim i tam otrzymal świadectwo maturalne. Wstąpił do seminarium duchownego w Poznaniu. Po otrzymaniu święceń diakonatu w 1869 roku został wysłany do Rzymu, gdzie uzyskal doktorat obojga praw w 1872 roku. Kilka miesięcy przygotowywal się $w$ seminarium gnieźnieńskim do święcen kapłańskich, które otrzymał w styczniu 1873 roku w Poznaniu z rąk arcybiskupa Mieczysława Ledóchowskiego. Został zaraz skierowany do seminarium $w$ Gnieźnie na stanowisko profesora repetenta prawa kanonicznego i obrońcy węzła małżeńskiego archidiecezji gnieźnieńskiej. Pełnił wiele odpowiedzialnych funkcji w administracji kościelnej ${ }^{1+1}$. Był oficjałem gnieźnieńskim po śmierci ks. biskupa-nominata Korytkowskiego ${ }^{142}$, a po śmierci arcybiskupa Dindera został zamieszczony na liście kandydatów na stolice arcybiskupią gnieźnieńską i poznańską. Ponieważ nie układała się wspólpraca $z$ nowym arcybiskupem Stablewskim, przeniósł się do Galicji i w maju 1892 roku wstąpił do Kongregacji Księży Filipinów w Tarnosvie. Tam szeroko rozwinąl dzialalność religijno-społeczną. Zmarł w Tarnowie 29 XII 1904 roku ${ }^{148}$.

$\mathrm{Ks}$. Eukowski byl najwybitniejszym kanonistą środowiska wielkopolskiego w końcu ubiegłego stulecia ${ }^{\mathbf{1 4 4}}$. Przez studia w Rzymie zdobył metodę ukierunkowaną na głębsze analityczne badania przepisów prawnych. Różniła się ona od metody historyczno-prawnej, która dominowała na uniwersytetach niemieckich. Posługiwanie się mało znaną na terenie archidiecezji gnieźnieńskiej i poznańskiej metodą analityczną miało duże znaczenie dla rozwoju nauki prawa kanonicznego. Studenci po slrończonych studiach w Poznaniu lub na uniwersytetach pruskich posiadali znajomość przepisów prawnych wraz $z$ ich rozwojem historycznym. W Gnieźnie nabywali głębszego zrozumienia ustaw kościelnych przez wnikanie w myśl prawodawcy, lingwistyczny rozbiór brzmienia i badanie lączności z innymi ustawami. Kis. Eukowski prowadził wykłady do chwili zamknięcia seminarium gneźnieńskiego przez władze pruskie ${ }^{145}$ i po wznotwieniu działalności. Obok pracy dydaktycznej rozwinąl ks. Łukowski pracę twórczą. Na wyszczególnienie zasługuje Instrukcja $w$ sprawie dyspens malżeńskich

\footnotetext{
${ }^{141}$ W o j c i ech ow sk a M., Łukowski Jan Nepomucen. W: Pol. słow. biogr. t. 18, Wrocław-Warszawa-Kraków-Gdańsk 1973, s. 565-566.

142 Przegląd Kościelny (red. Jaskulski) 10/1888/471.

${ }^{143} \mathrm{~W}$ o j c i e ch o ws k a M., Eukowski Jan, s. 566.

144 G I e m p J., Poczatki polskiej literatury o karności kościelnej Ks. Jan Opieliński (1858-1835), Prawo Kan. 20/1977/, nr 3-4 s. 225. 145 Seminarium gnieźnieńskie zostało zamknięte 11 IV 1875 roku.
} 
ogłoszona przez sw. Kongregację de Propaganda Fide, Poznań 1880 i Procedura hościelna podtug instrukcji Kongregacji biskupów i zakonników, Lwów 1881. Artykuły historyczno-prawne i recenzje podpisywane nieraz pseudonimem $\mathrm{X}$ Wokul publikowal na lamach Warty, Dziennika Poznańskiego, Kuriera Poznańskiego, Kuriera Polskiego i Przeglaqdu Lwowskiego. Był czlonkiem wydziału historyczno-literackiego Towarzystwa Przyjaciół Nauk Poznańskiego.

Dzięki wysiłkom władzy diecezjalnej i wykładowców, prawo kanoniczne $w$ seminariach archidiecezji gnieźnieńskiej i poznańskiej $w$ latach 1835-1873 osiągało wysoki poziom, który często przewyższal inne seminaria duchowne $\mathrm{w}$ Polsce, a nawet wydziały teologiczne na uniwersytetach.

\section{Studia kanonistyczne niektórych księży na wyższych uczelniach}

Po rozbiorach Polski Wielkopolska znalazła się pod zasięgiem prawa, kultury i nauki pruskiej. Władze panstwowe wymagały wykształcenia uniwersyteckiego od profesorów $w$ seminariach duchownych i gimnazjach, od sędziów i adwokatów oraz od innych ubiegających się o wyższe stanowiska $w$ administracji państwowej. $Z$ racji braku uniwersytetu na polskich terenach włączonych do Prus młodzież zmuszona była zdobywać wykształcenie na uniwersytetach zagranicznych, przeważnie pruskich.

Zakładaniem uniwersytetów $w$ wiekach średnich zajmowal się Kościoł. Stąd uniwersytety byly uczelniami katolickimi. Na początku XVI wieku, w krótkim czasie po wystąpieniu Lutra, 12 uniwersytetów niemieckich zerwało więź z Kościolem katolickim opowiadając się za nową religią. Od XVI wieku do pierwszych dziesiątków XIX wieku powstalo $w$ Niemezech 19 nowych uniwersytetów. W wyniku państwowego nacisku połączonego z zagrożeniem odebrania dochodów 9 uniwersytetów z biegiem czasu zmieniło swe założenia ideologiczne. Obok uniwersytetów katolickich i ewangelickich, 2 uniwersytety $w$ Bonn i we Wrocławiu były mieszane. Zależnie od ilości wydziałów były uniwersytety zupełne $i$ niezupełne ${ }^{14 \epsilon}$. Uniwersytety zupelne posiadały 4 a nawet 5 wydziałów: teologię, prawo, medycynę i filozofię. Po 5 wydziałów miały uniwersytety w Bonn, we Wroclawiu i Monachium. W Bonn i we Wrocławiu liczba wydziałów wzrosła z racji 2 odrębnych wydziałów teologicznych. Istniał wydział teologii katolickiej i usobny wydział teologii ewangelickiej. W Monachium natomiast $z$ i)stal stworzony wydzial statystyki obok teologii katolickiej, prawa, medycyny i filozofii 147 .

146 Tyg. Katol. 3/1862/11, dodatek.

$147 \mathrm{Hi}$ p e a M. E., Wychowanie publiczne $w$ Niemczech, Warszawa 1874 , s. 150,152 , wg drugiej paginacji. 
Do studiów na uniwersytecie upoważniało świadectwo dojrzałości ${ }^{148}$ Kandydaci musieli złożyé opłatę wpisową. Platne były również wszystkie wykłady. Studia trwały 3 lata tzn. 6 semestrów. Program nauczania układano na posiedzeniach wydzialu. Zwykle dziekan zbicrał oświadczenia co do materialu wykładowego $w$ danym semestrze, uzgadnial godziny zajęć z profesorami i prywatnymi docentami. Przede wszystkim zwracano uwágę, by studenci w ciągu trwania studiów mogli poznać wszystkie przedmioty $z$ dziedziny reprezentowanej przez dany wydział ${ }^{149}$. Zwykle raz $w$ tygodniu odbywał się $z$ każdego przedmiotu jeden wykład publiczny i cztery a nawet nieraz sześć wykładów prywatnych. W publicznych wykładach uczestniczyli sami studenci, a w prywatnych obok studentów brali udział tzw. wolni słuchacze. Na wielkich uniwersytetach zatrudniano 3 profesorów dla każdego przedmiotu, którzy w danym semestrze równocześnie wykladali ten sam materiał. Student sam wybierał jednego z nich i korzystal $z$.jego wykładów. Nie miało to wpływu na egzamin, poniewa do egzaminu powolywano specjalne komisje ${ }^{150}$.

Uniwersytety nadawaly tytuły: bakalaureatu, licencjatu i doktoratu. Podstawa uzyskania tytułu było opanowanie wykladanych na teologii, prawie i filozofii 18-24 przedmiotów, a na medycynie 24-30 przedmiotów ${ }^{151}$. Zdobycie tytułu uwarunkowane było przedstawieniem pisemnej pracy i dodatkowymi egzaminami. $Z$ tej racji nie wszyscy studenci starali się konczyć studia uzyskaniem tytułu. Aby otrzymać doktorat, należało przedstawić pisemną rozprawę, zlożyć egzamin i przeprowadzić publiczną dysputę.

Do grona profesorskiego należeli: prywatni docenci, profesorowie nadzwyczajni czyli tytularni, profesorowie zwyczajni honorowi i profesorowie zwyczajni. O uzyskanie stopnia prywatnego docenta można bylo wystąpić 2 lata po zakończeniu studiów na uniwersytecie. Wymagano od nich pisemnej rozprawy naukowej, specjalnych egzaminów i przeprowadzenia dysputy 152 (habilitacja). Tytuł nadawal wydział i zawiadamiał o tym ministerstwo wychowania publicznego. Prywatni docenci nabywali praw nauczania u siebie $w$ domu i na uniwersytetach. Stawali się tzw. samodzielnymi pracownikami nauki. Na uniwersytecie mieli możność wybrania przedmiotu wykladowego, o czym zawiadamiali rektora. Przedmiot wpisany był do urzędowego programu ${ }^{153}$. $Z$ grona prywatnych docentów odznaczających się uzdolnieniami pedagogicznymi rząd mianowal profesorów nadzwyczajnych, wynagradzając za wkład naukowy i tym samym dając możność awansu na stano-

148 S t o ińs ki J., Szkolnictwo średnie, s. 68.

$149 \mathrm{H}$ i p peau M. E., Wychowanie publiczne $w$ Niemczech, s. 150.

${ }^{150} \mathrm{H}$ i p p e a M. E., Wychowanie publiczne $w$ Niemczech, s. 154.

$151 \mathrm{H}$ ippeau M. E., Wychowanie publiczne $w$ Niemczech, s. 152.

$152 \mathrm{~N}$ ikel J., Die katholisch-theologische Fakultät, s. 161.

$153 \mathrm{~K} l$ ein id am E., Die katholisch-theologische Fakultät. Der Universität Breslau 1811-1945, Köln 1961, s. 159. 
wisko profesora zwyczajnego. Nie zawsze profesorowie nadzwyczajni otrzymywali stałe pensje. Główny ich dochód stanowiły opłaty wpisowe studentów, a wysokość zależała od ilości słuchaczy uczęszczających na ich, wykłady. Najwyższe stanowisko wśród ciała pedagogicznego mieli profesorowie zwyczajni, którzy byli kierownikami katedr. Obok nich byli również profesorowie zwyczajni honorowi. Ci nie posiadali własnych katedr i nie wchodzili w skład ściśle pojętego wy- działu ${ }^{154}$. Brak zapewnionych i wystarczających środków utrzymania na stanowisku prywatnych docentów i profesorów nadzwyczajnych wpływało zniechęcająco na młodych i uzdolnionych często absolwentów uniwersytetu. Zwykle kończyli studia uzyskaniem tytułu licencjata lub doktora. W omawianym przez nas okresie czasu, żaden z kapłanów archidiecezji gnieźnieńskiej i poznańskiej nie przeprowadził habilitacji na uniwersytecie. Zatrudnieni w miejscowym seminarium otrzymywali tytuł i prawa profesora nadzwyczajnego bez zachowania zwykłej procedury wiodącej do tego stanowiska.

Liczba uniwersytetów na terenie Prus była tak duża, że zaspokajała potrzeby zdobycia wiedzy na wyższym poziomie i uzyskania odpowiednich stopni naukowych. Zwyczaj wyjazdu na uczelnie zagraniczne nie byl $w$ Prusach tak zakorzeniony jak w Polsce. Jedynie od czasu do czasu młodzież duchowna dla zdobycia najczystszej „źródlowej" wiedzy teologicznej kierowała się do Collegium Germanicum w Rzymie. Rząd pruski zawsze niechętnie patrzyl na'studia zagranicą. Konstytucja $z$ dnia 31 I 1850 roku zagwarantowała Kościołowi wolność i samodzielność w sprawach wychowawcżych i szkolnych. Po trzech latach dnia $22 \mathrm{~V} 1853$ roku zabroniono niemieckiej młodzieży duchownej wyjeżdżać na studia teologiczne do Collegium Germanicum w Rzymie, na uniwersytet Propagandy Wiary lub do jakiegokolwiek zakładu wychowawczego kierowanego przez jezuitów. Wyjazd mógł nastąpić tylko po uprzednim uzyskaniu zgody władz państwowych ${ }^{155}$. $Z$ pelnej swobody korzystali studenci $w$ wyborze jednego $z$ uniwersytetów krajowych, w przechodzeniu z jednego uniwersytetu na drugi i zapisywaniu się na wykłady przez siebie wybrane ${ }^{156}$.

Studia duchowieństwa archidiecezji gnieźnieńskiej i poznańskiej na uniwersytetach poza granicami Prus w latach 1835-1873 należą do rzadkości. Arcybiskup Dunin zamierzal wyslać do Rzymu ks. Janiszewskiego $\mathrm{i} \mathrm{w}$ tym celu podjąl starania o umieszczenie go $\mathrm{w}$ Collegium Hungario-Germanico. Nie doszło jednak do realizacji tego planu ${ }^{157}$. W Rzymie studiował ks. Jan Koźmian, ale nie był tam kiero-

154 Hippeau M. E., Wychowanie publiczne $w$ Niemczech, s. 151 wg drugiej paginacji.

${ }_{155}$ Mystkowski S., Wychowanie i ksztatcenie kleru $w$ konkordatach XIX $i X X$ wieku, Ateneum Kapł. 23/1934/425.

${ }^{156} \mathrm{H}$ i p pea u M. E., Wychowanie publiczne $w$ Niemczech, s. 155.

157 AAP, Pismo arcybiskupa Dunina do Janiszews'kiego $\mathrm{z}$ dnia 23 III 1841, OA VI 396. 
wany przez władzę diecezjalną. Mieszkal w Rzymie u Księży Zmartwychwstańców 1 dopiero po ukończeniu teologii zgłosił się do arcybiskupa Przyłuskiego z prośbą o przyjęcie do seminarium ${ }^{158}$. Studia rzymskie posiadał ks. Jan Eukowski. Wyjechał do Rzymu po otrzymaniu święceń diakonatu $w$ roku 1869 i za trzy lata wrócił $z$ doktoratem obojg: praw ${ }^{159}$.

Wzorując się na zwyczaju archidiecezji wroclawskiej, część młodzie:ży wielkopolskiej po uzyskaniu świadectwa dojrzałości zapisywała się na wydzial teologiczny dowolnie wybranego uniwersytetu. $Z$ dyplomem ukończenia studiów zgłaszali się do seminarium $w$ Poznaniu, gdzie często zdawali przepisany egzamin i po krótkim czasie kierowani byli do Gniezna. Arcybiskup Przyluski wystosował pismo do rektorów alumnatów istniejących przy gimnazjach, by kandydatów do kaplaństwa kierowali do Poznania i odradzali zapisywania się na uniwersyteckie studia teologiczne oraz starania się na własną rękę o stypendium państwowe. Uważał, że roczny pobyt $w$ seminarium praktycznym jest okresem zbyt krótkim dla formacji duchowej, która powinna postępować razem ze zdobywaniem wiedzy. Gdy dowiedział się, że absolwenci gimnazjum poznańskiego Józef Preibisz z Rawicza i Wladysław Neryng z Kłecka na własną prośbę otrzymali stypendium rządowe, uprzedzil rektora, by nie przyjmowano ich dokumentów gdy będą prosić o przyjęcie do seminarium ${ }^{160}$. Było to bardzo ostre zastrzeżenie, jeśli weźmiemy pod uwage, że do rektora należało skompletowanie pism kandydata i odesłanie do arcybiskupa, który osobiście decydował o przyjęciu. W wysyłaniu kleryków na uniwersytety wiele do powiedzenia miał rektor seminarium, który przedstawial ar"cybiskupowi odpowiednio uzdolnionych ${ }^{161}$. Nie bylo ustalonej zasady co do zaawansowania w studiach. Wysyłano po trzecim, drugim a nawet po pierwszym roku studiów w Poznaniu. Liczba kierowanych na uniwersytety gdzie $w$ ramach studiów teologii zdobywano wiedze kanonistyczną, uzależniona byla od środków materialnych uzyskanych na utrzymanie $w$ mieście uniwersyteckim.

Typowani na studia uniwersyteckie przez władzę duchowną pochodzili zwykle $z$ warstwy uboższej i nie posiadali zasobów finansowych na pokrycie opłaty wpisowej, wykladów i utrzymania. Archidiecezja gnieźnieńska i poznańska posiadała dwa fundusze przeznaczone dla studentów teologii. Fundusz gnieźnieńsko-żniński oddało państwo w zarząd kościelny, gdy wprowadzano w życie postanowienia bulli $D e$

158 Likowski E., Mowa żatobna na cześć s. p. $x$ Jana Koźmiana pralata domowego Jego Swiatobliwosci, protonotariusza apostolskiego i kanonika metropolitalnego poznańskiego, zmarłego $w$ Wenecji dnia 19 września 1877 roku, miana na nabożènstwie żalobnem $w$ koscieie katedralnym pozn. dnia 29 września tegoż roku, Poznań 1877, s. 15.

159 Wo jciechow s a M., Eukowski Jan Nepomucen, s. 565 .

160 AAP, Pismo arcybiskupa Przyłuskiego $z$ dnia 11 XII 1850, SD 11. 101 AAP, SD 10. 
salute animarum. Podstawą drugiego funduszu była kwota wydzielona w 1833 roku $z$ pieniędzy przeznaczonych na utworzenie konwiktu wrocławskiego dla studentów archidiecezji gnieźnieńskiej i poznańskiej. Sprawę przydzielania stypendiów w okresie rządów arcybiskupa Dunina załatwiano kompromisowo. Część stypendiów otrzymywali klerycy typowani przez arcybiskupa, a naczelny prezes przydzielał stypendia maturzystom, którzy nie wiążąc się $z$ określonym seminarium pragnęli studiować teologię na uniwersytecie. W latach 18481850 naczelny prezes wytypowal 12 stypendystów, a tylko 4 arcybiskup. Broniąc swego prawa do przydziału stypendiów, arcybiskup Przyluski odniósł się do ministerstwa, które formalnie odmówiło naczelnemu prezesowi prawa ingerencji w przydzielanie stypendiów i na zasadzie art. 18 konstytucji przyznało rację arcybiskupowi ${ }^{162}$.

Część studentów teologii korzystała $\mathrm{z}$ funduszów przydzielonych $\mathrm{z}$ kasy Towarzystwa Pomocy Naukowej, założonego w Poznaniu przez doktora Jana Karola Marcinkowskiego-w 1841 roku. Celem tego towarzystwa było wydobyć „z mas ludu zdatną młodzież, a wykrywszy jej talenta, obrócić ją na pożytek kraju, dając pomoc i stosowny kierunek jej wykształceniu" ${ }^{163}$. W pierwszych 16 latach istnienia towarzystwa ze stypendiów korzystało 11 studentów teologii ${ }^{164}$.

Liczba studiujących teologię na uniwersytetach niemieckich korzystających $z$ funđuszów stypendialnych była dość pokaźna. Widać to wyraźnie, gdy weźmie się pod uwage stosunek odbywających studia: na uniwersytetach do ogólnej liczby kleryków w seminarium gnieźnieńskim i poznańskim. W latach $1835-1849$ było $w$ tych seminariach od 13 do 36 alumnów, a w latach 1850-1867 liczba wzrosła od 46 do $120^{165}$. W 1862 roku w Monasterze, Monachium i Fryburgu było 11 studentów teologii $z$, diecezji gnieźnieńskiej i poznańskiej ${ }^{166}$, a w 1866 roku w samym tylko Monasterze studiowało 8 Polaków ${ }^{167}$, najprawdopodobniej wszyscy pochodzili z Wielkopolski.

162 Zieliński Z., Kościót katolicki $w$ Wielkim Księstwie Poznariskim, s. $212-213$.

${ }_{163}$ Jakó bcz y k W., Jan Karol Marcinkowski (1800-1846). W: Wybitni Wielkopolanie, Poznaŕ 1959, t. 1, s. 118, red. Jakóbczyk W. Spośród duchowieństwa wielkie zasługi dla tej instytucji mają ks. Jan. Jabczyński i ks. Józef Brżeziński. Pierwszy bral udzial w zebraniu konstytucyjnym, drugi przez 36 lat był giownym motorem prac centrali. Arcybiskup Dunin zachęcal duchowieństwo do wspólpracy z towarzystwem.

${ }_{164} \mathrm{Z}$ i elinski Z., Kościót katolicki $w$ Wielkim Księstwie Poznańskim, s. 214.

${ }^{165} \mathrm{~F}$ a b is z P.; De Archiepiscopatu, s. 78.

166 Tyg. Katol. 3/1862/417.

${ }^{167} \mathrm{~K}$ a r bowiak A., Mlodziej Polska akademicka za granica 1795-1910, Kraków 1910, s. 80. 


\section{Studia kanonistyczne na uniwersytecie wroctawskim}

Młodzież wielkopolska najczęściej udawała się na studia uniwersyteckie do Wrocławia. Na wybór tej uczelni decydujący wpływ miała bliskość i z tym związana łatwość dojazdu. Stolice Sląska i Wielkopolski dzieli odległość około $200 \mathrm{~km}$. We Wrocławiu studiowała spora grupa polskiej młodzieży z Górnego Sląska, przez co atmosfera tego środowiska posiadała więcej elementów słowiańskich niż w innych miastach uniwersyteckich na terenie Prus. W takim otoczeniu lepiej czuli się studenci $z$ Wielkopolski. Pierwszymi studentami teologii na uniwersytecie wrocławskim po 1821 roku byli: Brzeziński Józef, Jabczyński Jan, Kidaszewski Andrzej, Kropiwnicki Józef Edward i Loga Adam ${ }^{168}$.

Wrocław już na początku XVI wieku otrzymał od króla węgierskiego i czeskiego Władysława Jagiellończyka generale litterarum gymnasium z 4 wydziałami: sztuk wyzwolonych, prawa rzymskiego i kościelnego, medycyny i teologii ${ }^{169}$. Rada miejska wniosła prośbę o zatwierdzenie tej uczelni, ale Rzym ustosunkowal się negatywnie. W połowie XVII wieku jezuici założyli kolegium z pełnymi studiami, które w 1702 roku zostało przekształcone w dwuwydziałową akademię zwaną Leopoldina od imienia cesarza Leopolda $I^{170}$. Po wojnie 1806/1807 roku zajęto się reorganizacją szkolnictwa wyższego. Przez stworzenie uniwersytetu $w$ Berlinie stracil swoje znaczenie uniwersytet $w$ Frankfurcie nad Odrą zwany Viadrina. Król Fryderyk Wilhelm III rozkazem gabinetowym z dnia 24 IV 1811 roku przeniósł uniwersytet. frankfurcki do Wroclawia. Zachowano 4 poprzednie wydziały: teologie protestancką, prawo, medycynę, filozofię i dołączono piąty teologię katolicką z Leopoldiny. Profesorów filozofii frankfurckiej i wroclawskiej połączono w jeden wydział ${ }^{171}$. Dnia 21 II 1816 roku uniwersytet otrzymał własne statuty, a w 1840 roku wprowadzono własne regulaminy dla poszczególnych wydziałów. Od 1829 roku wydzial teologiczny w układaniu planu wykładów wzorował się na uniwersytecie w Bonn ${ }^{172}$. Statuty z 1816 roku wymagaly na teologii i filozofii trzechletnich studiów i uprawniały do nadawania stopni licencjatu i doktoratu. Wydzial teologiczny na mocy tych statutów nie uzyskał prawa promocji na doktora canonum. Po studiach medycyný czy prawa można było zyskać tylko tytuł doktora ${ }^{173}$.

Przez kilkanaście lat od chwili reorganizacji uniwersytet nie byk w stanie rozwinąć szerokiej działalności naukowej. W 1811 roku po-

\footnotetext{
168 Tyg. Katol. 10/1869/484.

${ }_{169} \mathrm{~B}$ a r y cz H., Uniwersytet wroctawski $w$ przeszlości i teraźniej-. š̃ości, Katowice 1946, s. 7.

170 P etrani A., Nauka prawa kanonicznego, s. 260-251.

$171 \mathrm{~B}$ a r y с z H., Uniwersytet wroclawski, s. 16-17.

${ }_{172}$ Petrani A., Nauka prawa kanonicznego, s. 263.

$173 \mathrm{Nike} 1$ J., Die katholisch-theologische Fakultät, s. 159-160.
} 
siadał 51 wykładowców, w tym 35 profesorów zwyczajnych, 4 nadzwyczajnych, 4 prywatnych docentów i 8 lektorów. Nie wielu było wybitniejszych naukowców, a kilku profesorów nie posiadało doktoratu. Profesor zatrudniony na określonym wydziale musiał znać wszystkie gałęzie wiedzy wykładane na tym wydziale. Nie dostrzegano potrzeby specjalizacji ${ }^{\mathbf{1 7 4}}$.

Prawo kanoniczne wykładane było we Wrocławiu na wydziale teologicznym i prawnym, gdzie obok prawa rzymskiego i państwowego posiadało wysoką rangę. Pierwszym profesorem prawa kanonicznego na wydziale teologicznym uniwersytetu wrocławskiego był Slązak ks. Marcin Pełka, który weześniej wyłładał ten przedmiot w Akademii Leopoldyńskiej.

Ks. Marcin Pelka ur. 4 XI 1757 roku w Brożcu koło Prudnika. Pierwsze nauki otrzymał w rodzinnej wiosce. $Z$ domu nie wyniósł dostatecznej znajomości języka niemieckiego. Do gimnazjum uczęszczal w Glubczycach, a w latach 1775-1777 studiowal na Akademif Leopoldyńskiej we Wroclawiu w ramach filozofii: logike, matematyke, fizykę, historię i katechetykę. W 1777 roku udał się do Wiednia, gdzie przez dwa lata słuchal wykładów filozofii i prawa. Po powrocie do Wrocławia rozpoczął studia teologiczne. Na zakończenie przedłożyl rozprawę Positiones et Questiones ex universa theologia dogmatica, quas in alma caesarea, regiaque Universitate Leopoldina Vratislaviensi propugnandas, et resolvendas suscipere Reverendus, Doctissimus, ac Praecellens D. Martinus Pelka, Silesius Brozecensis. Anno 1782. Vratislaviae. Litteris academicis ${ }^{175}$. Swięcenia kapłańskie otrzymal $\mathrm{z}$ rąk biskupa Antoniego Ferdynanda Rothkircha dnia 22 XII 1781 roku.

W duszpasterstwie ks. Pelka pracował 4 lata. Pierwsze dwa lata pelnił obowiązki duchownego pomocniczego i kaznodziei $w$ Brzegu nad Odrą, a następnie był kaznodzieją w kościele uniwersyteckim we Wrocławiu: Od 1801 roku byl radca konsystorza, a w 1812 powołany został na radcę generalnego wikariatu. Z nominacji królewskiej otrzymał w 1814 roku kanonię przy kościele katedralnym we Wrocławiu. Godnością prałata scholastyka obdarzony został w 1823 roku. Zmarł 5 XI 1828 roku ${ }^{176}$.

Ks. Pelka blisko 42 lata byl profesorem Akademii Leopoldyńskiej i na Uniwersytecie wrocławskim. W latach 1786-1789 wykładał: metafizyke, estetykę, filozofię i prawo natury, a od 14 I 1789 roku obją1 wykłady prawa kanonicznego. Oprócz tego powierzono $\mathrm{mu}$ w pewnym

174 В а г у с z H., Uniwersytet wroctawski, s. 18-19.

$175 \mathrm{Urbari}$ W., Ks. Marcin Petka - ślaski kanonista (1757-1828), Prawo Kan. 14/1971/, nr 1-2, s. 326-327; Kle in e id a m E. Die Katholisch-theologische Fakultät, s. $145 ; \mathrm{H}$ a a s e F., Leben und Schriften der kath. theol. Dozenten, s. 86.

${ }^{176}$ U r ba n W., Ks. Marcin Pelka, s. 327; Kleineidam E., Die katholisch-theologische Fakultät, s. 145. 
czasie nauczanie jęzka polskiego, historii teologii, literatury, historii Kościola, patrologii, encyklopedii teologicznej i teologii dogmatycznej ${ }^{177}$. Prawo kanoniczne wykładał po lacinie dwie godziny tygodniowo obejmując cały materiał $w$ ciągu 2 lat ${ }^{178}$. Wszystkie zagadnienia $z$ tej dziedziny zamykal w przybliżonej liczbie 160 wykładów. Prelekcje tego przedmiotu mialy charakter publiczny ${ }^{179}$. Materiał z zakresu prawa kanonicznego ujął $w$ dwutomowy podręcznik pt. Iuris ecclesiastici analysis. Pars prior. Prolegomena ac Ius ecclesiasticum publicum. Vratislaviae. Typis Universitatis 1795, $8^{\circ}$ ss. VIII, 228; Pars posterior. Ius ecclesiasticum privatum, Vratislaviae $1796,8^{\circ}$ ss. VII, 407, 1 nlb. Przy opracowaniu posłużyl się dziełem Bernarda Bolla Iuris ecclesiastici analysis, Salemii 1794, które znacznie powiększył i w wielu kwestiach przerobił. W kwestii stosunku Kościoła do państwa reprezentował umiarkowany józefinizm ${ }^{180}$.

Po odejściu ks. Pelki na emeryturę katedra prawa kanonicznego nie została zaraz obsadzona. Zagadnienia prawne zmuszeni byli podjąć profesorowie innych dyscyplin, by studentom przekazać całokształt wiedzy teologicznej wykładanej wg przyjętego programu studiów akademickich. W semestrze letnim 1824 roku prawo kościelne pruskie wyikladał prof. Herber, a w zimowym semestrze $1825 / 1826$ prawa kanonicznego uczył prof. Dereser ${ }^{\mathbf{1 8 1}}$.

Ks. Karol Herber ur. 10 I 1788 roku w Nasiedlu koło Głubczyc w diecezji olomunieckiej. Do gimnazjum uczęszczał w Głubczycach. Na uniwersytecie wroclawskim 5 lat studiował filozofię i teologię, uzyskując doktorat filozofii. Swięcenia kapłańskie przyjął 9 III 1811 roku. Krótko pracowal jako wikariusz w Tropplowitz i został nauczycielem religii w gimnazjum katolickim św. Macieja we Wrocławiu (1811-1819). Juź w 1814 roku rozpoczął wykładać na uniwersytecie jako profesor nadzwyczajny, a od 1819 roku jako profesor zwyczajny egzegezy Starego Testamentu i historii Kościoła. W 1825 roku objął jeszcze wykłady patrologii i teologii moralnej. Uzyskał odpowiednie stopnie akademickie uprawniające do wykładania przedmiotów teologicznych. W roku 1831 zrezygnowal doborowolnie z profesury. Zmarł 17 XI 1853 roku ${ }^{182}$.

Z twórczości naukowej Herbera na szczególną uwagę kanonistów zasługuje Silesiae sacrae origines, Vratislaviae 1821, z dołączonymi tabli-

177 Urban W., Ks. Marcin Pelka, s. $32 \%$.

176 Petran i A., Nauka prawa kanonicznego, s. 265

${ }^{179} \mathrm{~K}$ leineid a m E., Die katholisch-theologische Fakultät, s. 23.

${ }^{100}$ Petrani A., Nauka prawa kanonicznego, s. 265; Boll byl jozuita, później cystersem. a od 1827 roku arcybiskupem Fryburga Badeńskiego. Wykładal prawo kanoniczne w opactwie Salem.

181 B rzeziński A., Zywot ks. Kidaszewskiego, s. 46-49.

18: Engel bert K., Geschichte des Breslauer Domkapitels 1800-1945, Fildesheim 1964, s. 282. 
cami chronologicznymi i Statistik des Bistums Breslau, Breslau $1825^{183}$. Razem z profes orem ks. Józefem Ritterem i proboszczem Karolem Dittersdorfem wydawał Breslauer Zeitschrift für katholische Theologie ${ }^{184}$. Czasopismo wychodziło przez dwa lata w 1832 i 1833 roku ${ }^{185}$.

Gdy zaczął pracę na uniwersytecie był jednym $z$ nielicznych młodych wykładowców. W roku akademickim $1827 / 28$ był jedynym czynnym profesorem zwyczajnym na wydziale teologii katolickiej. $\mathrm{Na}$ wykładach kościelnego prawa pruskiego wyjaśniał ustawy państwowe dotyczące działalności Kościoła. Stosownie do panującego wówczas zwyczaju wiele kwestii prawa kościelnego wlączal w wykłady historii Kościola, patrologii i teologii moralnej.

Ks. Antoni Dereser ur. 3 II 1757 roku $w$ Fahr nad Menern. Do 1802 roku był karmelitą. Swięcenia kaplańskie otrzymal 11 III 1780 roku ${ }^{186}$. W krótkim czasie po święceniach został profesorem w Heidelbergu, w 1783 roku w Bonn, w 1791 rektorem seminarium duchownego i kaznodzieją katedralnym w Strassburgu. Przeżył okrucieństwa rewolucji francuskiej. Groziła mu śmierć ponieważ odmówił złożenia przysięgi na Konstytucję Cywilną Duchowieństwa, która usilowała Kościól we Francji całkowicie podporządkować władzy świeckiej. Dereser ocalał dzięki upadkowi Robespierre'a. Wrócil w 1797 roku do Heidelbergu, od 1807 roku byl proboszczem we Fryburgu, 1810 roku proboszczem w Karlsruhe, 1811 roku profesorem i rektorem seminarium w Lucernie, 1815 roku profesorem we Wroclawiu ${ }^{187}$. Tu został 19 II 1819 roku kanonikiem gremialnym kapituły. Zmarł 16 VI 1827 roku.

Na uniwersytecie we Wrocławiu wykładał dogmatykę, egzegezę Stitrego Testamentu ${ }^{188}$ i encyklopedię teologii, która nie była samodzielną dyscypliną, lecz wprowadzeniem do całych studiów teologicznych ${ }^{189}$. Reprezentował kierunek racjonalistyczny i ze względu na to popadal często $w$ konflikty $z$ władzami kościelnymi i państwowymi. Zmuszony byl zmieniać miejsce pracy, ale zaraz otrzymywał inne lub wracal na dawne. Przetlumaczył na język niemiecki biblię i brewiarz. Praca pt. Commentatio bibl. in effatum Christi: Tu es Petrus, dostała się w 1790 roku na indeks. Jego przemyślenia filozoficzne i liczne konflikty odbijały się również na wykladach prawa kanonicznego, a przetłumaczony brewiarz i poglądy na liturgię $w$ języku narodowym otwierały szeroko brame do wystąpień, które w owym czasie wyrządzily Kościolowi duże szkody.

${ }^{183} \mathrm{H}$ a a s e F., Leben und Schriften der kath. theol. Dozenten, s. 45. 184 Engel lbert K., Geschichte des Breslauer Domkapitels, s. 282. ${ }^{185} \mathrm{H}$ a a s e F., Leben und Schriften der kath. theol. Dozenten, s. 113. 186 Engelbert K., Geschichte des Breslauer Domkapitels, s. 279. ${ }_{187} \mathrm{Greving}$ J., Dereser $A$. W: Kirchliche Handlexikon, München $1906-1912$, t. 1 , s. 1075.

${ }^{189}$ Engelbert K., Geschichte des Breslauer Domkapitels, s. 279.

${ }^{189} \mathrm{Nikel}$ J., Die katholisch-theologische Fakultät, s. 153. 
Wadze uniwersyteckie podejmowały starania, by jak najszybciej obsadzić wakujące stanowisko profesora prawa kanonicznego. $\mathrm{Na}$ polecenie ministra oświaty, wydział podał nazwiska absolwentów, którzy byli przygotowani do nauczania tego przedmiotu. Wśród 9 kandydatów znalazl się na liście kapelan i sekretarz arcybiskupa gnieźnieńskiego i poznańskiego ks. Jan Zienkiewicz ${ }^{190}$. Dzięki poparciu kuratora uniwersytetu, na stanowisko profesora nadzwyczajnego prawa kanonicznego i egzegezy biblijnej zostal powolany z grona przedstawionych ks. Antoni Theiner brat historyka ks. Augustyna Theinera.

Ks. Antoni Theiner ur. 15 XII 1799 roku we Wrocławiu, uczęszczał do gimnazjum św. Macieja, a potem studiowal teologię ${ }^{191}$. Studia ukończył'z odznaczeniem uzyskując 17 IV 1823 roku doktorat teologii 192. Swięcenia kapłańskie otrzymal w 1822 roku. Pracowal w duszpasterstwie jako wikariusz w Sobocie kolo Lwówka Sląskiego i w Legnicy, a po opuszczeniu stanowiska profesora był proboszczem w Pelcznicy (1830-1836), w Krzeszowie (1836-1837) i w Psim Polu koło Wrocławia (1837-1845). Na krótiki czas związał się z sektą Rongego, za co zostal oficjalnie ekskomunikowany. Przez 10 lat mieszkal we Wrocławiu bez urzędowego zajęcia. W 1855 roku został powolany przez władze państwowe na stanowisko sekretarza biblioteki uniwersyteckiej. Przed śmiercią przeszedi na protestantyzm. Zmarł 15 V 1860 roku ${ }^{193}$.

Wykłady na wydziale teologicznym uniwersytetu wrocławskiego rozpocząl ks. Theiner $w$ zimowym semestrze 1824 roku. W krótkim czasie przeprowadzil habilitacje. Podczas zimowego semestru 1825/26, gdy prawo kanoniczne wykladal ks. Dereser, ks. Theiner prowadzil tzw. disputatorium o prawie kanonicznym ${ }^{194}$. Z określenia wynika, że był to pewien rodzaj ćwiczeń $z$ tego przedmiotu, mających na celu uzasadnienie calego systemu prawnego Kościoła przez podanie dowodów czerpanych z filozofii i teologii. Nadmierna pewność siebie, żywy temperament $i$ trudności $w$ obcowaniu $z$ innymi stały się przyczyną złośliwej krytyki hierarchii kościelnej, celibatu i liturgii. Już latem 1825 roku docieraly do biskupa Emmanuela Szymońskiego wiadomości o nastawieniu ks. Theinera. Zobowiązano go do wytłumaczenia się, po którym otrzymał upomnienie od biskupa i wydziału. W następnym roku wydal książkę pt. Die katholische Kirche Schlesiens dargestellt von einem katholischen Geistlichen, Altenburg'1826, której tytuł w drugim wydaniu brzmiał: Die katholische Kirche besonders in Schlesien in ihren Gebrechen dargestellt von einem katho-

\footnotetext{
$190 \mathrm{~N}$ ike1 J., Die katholisch-theologische Fakultät, s. 116 przypis. $191 \mathrm{H}$ a a s e F., Leben und Schriften der kath. theol. Dozenten, s. 138.

19:2 Petrani A., Nauka prawa kanonicznego, s. 267.

${ }_{193}$ Schlecht J., Theiner A., W: Kirchl. Handl., t. 2, s. 2340.

194 Brzezińs ki A., Zywot ks. Kidaszewskiego, s. 49.
} 
lischen Geistlichen. Ponieważ godziła w instytucję Kościoła została wpisana na indeks.

Biskup Szymoński dnia 7 VII 1826 roku podal wniosek do ministra oświaty o zawieszenie wykładów ks. Theinera. Ministerstwo poleciło powierzyć ks. Theinerowi wykłady przedmiotu teologicznego, motywując że prawo kanoniczne nie należy do wydzialu teologicznego lecz do wydziału prawnego. Zaznaczono, że ministerstwo nie wie czy ks. Theiner posiada doktorat prawa kanonicznego. Faktycznie, profesor posiadał tylko doktorat $z$ teologii. Przedstawił więc na wydziale priwa rozprawę, zdał kolokwium i dnia 14 XII 1826 roku uzyskał promocję, którą ministerstwo z jakiegoś formalnego blędu unieważniło i zakazało mu aż do odwołania starać się o nową promocję na doktora ubojga praw czy prawa kanonicznego. Dnia 17 II 1827 roku ministerstwo cofnęlo ks. Theinerowi zezwolenie na wykłady prawa kościelnego, homiletyki i teologii pastoralnej, pozostawiając egzegeze Starego Testamentu, a kurator uniwersytetu nakazal wydziałowi polecic, by profesor podczas wykladów unikał wszystkiego co może wywolać obraze lub zgorszenie. Biskup natomiast przedstawil wniosek o przeniesienie ks. Theinera $z$ Wrocławia na inny uniwersytet. Gdy w koncu 1828 roku uisazala się książka pt. Die Einführung der erzwungenen. Ehelosigkeit bei den christlichen Geistlichen und ihre Folgen, której autorami byli bracia Antoni i Augustyn Theinerowie, zawrzala burza. Praca zawierała dużo materiału historycznego, który głównie pochodził od Augustyna. Biskup Szymoński zażądał usunięcia profesora gloszącego antykatolickie zasady, a potem zagrozil, że jego sluchaczy nie dopuści do święceń kapłańskich. Ministerstwo nakłoniło ks. Theinera do porozumienia się $z$ władzą kościelną. Po pewnym czasie doszlo do spotkania ks. Theinera z biskupem, który potraktował go po ojcowsku. Na skutek przeprowadzonej rozmowy ks. Theiner zrezygnowal z profesury i przeniósł się na probostwo ${ }^{195}$. Takie rozwiązanie $w$ tej sprawie podsunął biskupowi ks. profesor Pełka ${ }^{196}$.

$\mathrm{Z}$ dziedziny kanonistycznej ks. Theiner wydal: Variae doctorum catholicorum opiniones de iure statuendi impedimenta matrimonium dirimentia, 1825 i De Pseudo Isidoriana canonum collectione 1827. Oba dzieła były kompilacjami. Szczególnie Variae doctorum... opiniones... dają obraz poglądów, które ks. Theiner szerzył przez wyklady i pisma. We wspomnianym dziele przyznaje, że Chrystus podniósł małżeństwo do godności sakramentu i $w$ tej dziedzinie podlega ono Kościołowi. Jest jednak kontraktem i $w$ tym zakresie zależy od ustawodawstwa państwowego. $Z$ tej racji nie Kościól, ale władza świecka ma prawo ustanawiać przeszkody zrywające. Kościół zawsze uważał za nieważne te małżeństwa, których nieważność określała wladza świecka. Autor stwierdza, że taką naukę gloszono już dawno

195 Petran i A., Nauka prawa kanonicznego, s. 166-167.

196 Ur ban W., Ks. Marcin Pelka, s. 329. 
i na poparcie swych wywodów powoluje się na wielu autorów ${ }^{197}$. Była to prawie w całości nauka głoszona przez Lutra i jego następców.

Po wydaniu zakazu prowadzenia wykładów prawa kanonicznego przez ks. Theinera, przedmiot ten 4 lata nie był wykładany w ramach teologii. Władze wydzialu $w$ piśmie do ministerstwa wykazywały, $\dot{z} e$ wykłady prawa kanonicznego na wydziale teologii były od chwili zorganizowania uniwersytetu wrocławskiego zawsze oglaszane i prowadzone ${ }^{198}$. Nowego profesora prawa kanonicznego $w$ osobie ks. Jerzego Dominika Berga mianowano w 1831 roku.

Ks, Jerzy Dominik Berg ur. 19 VI 1798 roku w Woltlage kolo Monasteru. Kapłanem został w 1821 roku i pracował jako nauczyciel religii w królewskim gimnazjum w Monasterze. Dnia 14 IX 1831 roku zostal powolany do Wrocławia na profesora teologii moralnej. W 1837 roku otrzymal nominacje na kanonika przy katedrze wrocławskiej. Nie nastąpiła jednak instalacja, ponieważ zmarł 19 VII 1837 roku w Reinerz ${ }^{199}$.

$Z$ racji braku profesorów, ks. Berg obok teologii moralnej wykładał prawo kanoniczne, teologię dogmatyczną i pasterską. Początkowo był profesorem nadzwyczajnym, a w 1834 roku zostal profesorem zwyczajnym wymienionych dyscyplin ${ }^{200}$. Wczesną śmierć przypisują autorzy przemęczeniu, które nastąpiło $z$ racji wielu zajęć dydaktycznych i pracy twórczej. $Z$ dziedziny prawa kanonicznego zasługują na uwagę 3 wartościowe pozycje podające zdrową katolicką naukę: Úber das Eheband. Eine dogmatisch-kirchenrechtliche Abhandlung über I Cor. 7, 15, 1829; Uber die Verbindlichkeit der kanonischen Ehehindernisse inbetreff der Ehe der Evanglischen eine kirchenrechtliche Abhandlung, 1835; Uber die Erforderlichkeit der priesterlichen Einsegnung. zum Sakramente der Ehe, $1836{ }^{201 .}$

Po śmierci ks. Berga katedra prawa kanonicznego na wydziale teologicznym nie byla długi czas obsadzona. Dopiero w roku 1882 habilitował się $z$ historii Kościola i prawa kanonicznego ks. Maksymilian Sdralek. W tym okresie zagadnienia celibatu i obowiązków duch owieństwa omawiali profesorowie innych dyscyplin ${ }^{202}$. I tak $w$ zimowym semestrze $1849 / 50$ roku prowadzil bezpłatnie dyskusje o celibacie licencjat teologii katolickiej Wick ${ }^{203}$. Wrocławscy studenci przez pewien czas mieszłali w alumnacie i tam mieli możność uzupełnić wiadomości z prawa kanonicznego. Studenci z archidiecezji gnieźnień-

${ }^{197} \mathrm{H}$ a a s e F., Leben und Schriften der kath. theol. Dozenten, s. $139-140$.

198 P etrani A., Nauka prawa kanonicznego, s. 266.

199 Engel bert K., Geschichte des Breslauer Domkapitels, s. 281.

$200 \mathrm{~N}$ i ke1 J., Die katholisch-theologische Fakultät, s. 122.

${ }^{201} \mathrm{H}$ a a s e F., Leben und Schriften der kath. theol. Dozenten, s. 11.

$202 \mathrm{~N}$ ikel J., Die katholisch-theologische Fakultät, s. 152.

203 AAP, Prelekcje wysluchane na uniwersytecie wrocławskim przez. Marcina Matheya, SD 11. 
skiej i poznańskiej korzystali jedynie z wykładów prawa kanonicznego na wydziale prawa.

Regulamin wydany w 1840 roku wyliczal prawo kanoniczne wśród przedmiotów wykładanych na teologii i nadmieniał, że studenci teologii mają słuchać prawa kanonicznego na wydziale prawnym $w$ tym okresie, gdy teologia nie będzie miała profesora tego przedmiotu. Wradze kościelne $\mathrm{z}$ takiego postawienia sprawy nie były zadowolone, ponieważ często prawo kanoniczne wykładał protestant, który nie zawsze umiał zdobyć się na podawanie obiektywnej prawdy. Na interwencje składane do ministerstwa zostal wydany dnia 26 IX 1853 roku rozkaz gabinetowy, na mocy którego prawo kościelne na wydziale prawnym miało być wykładane przez dwóch profesorów: katolika i protestanta ${ }^{204}$. Katolickimi wykładowcami prawa kościelnego na wydziale prawnym byli: profesor Regenbrecht, docent Grosch i profesor Gitzler.

Michał Edward Regenbrecht ur. 1792 roku. Studiował na uniwersytecie berlińskim. Tam przedstawił rozprawę pod tytułem Commentatio ad L. XXXVI D. de acq. rer. dom. et $L$. XVIII D. de reb. cred. i dnia 8 VII 1820 roku otrzymal tytul doktora obojga praw. Dysputę prowadzil wobec 3 oponentów: Juliana Fryderyka Henryka Abegga, Jerzego Juliana Ribbentropa i Ernesta Teodora Gauppa. Do Wrocławia przybył Regenbrecht w 1820 roku i rozpocząl zajęcia dydaktyczne na wydziale prawnym uniwersytetu wykładami prawa naturalnego i filozofii prawa (1820-1821) ${ }^{205}$. Wykładal prawo rzymskie, prawo międzynarodowe, ale najbardziej związał się z katedrą prawa kościelnego. W zimowym semestrze 1821/22 pomagal profesorowi Madihnowi, po którym objął stanowisko. Program wykładów, które prowadzil Regenbrecht w letnim semestrze 1839 roku wykazuje tygodniowo aż 6 godzin prawa kościelnego i 2 godziny historii tegoż prawa. Prace drukowane Regenbrechta nie mają większego znaczenia. Sa to wlaściwie rozprawy dla uzyskania stopni naukowych. Disputationes de origine regimine ecclesiastici particula I, 1824, przeznaczona dla uzyskania promocji na profesora nadzwyczajnego jest słabszą niż w/w rozprawa doktorska. Cała obejmuje 38 stron. W tym 14 stron zajmuje wstęp, a pozostałe strony stanowią jeden rodział zatytułowany De vita, doctrina, rebusque gestis auctoris ecclesiae christianae. W 1828 roku opublikowal rozprawę habilitacyjną na profesora zwyczajnego pt. De canonibus apostolorum et codice ecclesiae Hispanae. Tu stanął na stanowisku, ze canones apostolorum pochodzą z V wieku i przyjęte zostały od razu przez cały Kościól grecki, a na język íacinski przełożył je dopiero Dionizy. Przy omawianiu kodeksu Koś-

\footnotetext{
204 Petrani A., Nauka prawa kanonicznego, s. 268

205 G r e t o n e r X., Naturrecht und Rechtsphilosophie. W: Festschrift zur Feier des hundertjährigen Bestehens der Universität Breslau, red. Kaufmann G., Breslau 1911, t. 2, s. 237.
} 
ciola hiszpańskiego posłużył się autor wydaniem madryckim ${ }^{206}$. Czystość nauki podawanej na wykładach budziła zastrzeżenia. Dalekie od zasad katolickich było życie rodziny Regenbrechta. Wreszcie sam

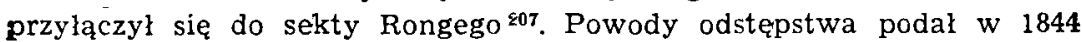
roku w dwustronicowej ulotce zatytułowanej: Erklärung des Professors des kanonischen Rechts an der hiefigen Universität ... an den Bisthums Verweser und Weihbischof der Latussek über sein Ausscheiden aus der römisch-katholischen Kirche..., Breslau 1844. Wśród wielu pytań retorycznych twierdził, że Kościół katolicki jest mało postępowy, a ustosunkowanie się wladzy kościelnej do Rongego obraziło jego delikatne uczucie religijne. W następnym roku wydane zostało dalsze naświetlenie tej sprawy pt. Offenes Sendschreiben an Prof. Regenbrecht üb. s. Erkärung in Betreff s. Ausscheidens a. d. röm. kath. Kirche von Franz Peschke s. Kirche christ. Katholische ${ }^{208}$. Regenbrecht nie wrócil na łcno Kościola katolickiego. Zmarł na cholere w 1849 roku.

Korzystny dla nauki prawa kanonicznego był fakt, że już w 1835 roku rozpoczął prace na wydziale prawnym uniwersytetu wrockawskiego katolik Ludwik Antoni Gitzler, który przez kilkadziesiąt lat pracy dydaktycznej podawał zdrową naukę katolicką.

Ludwik Antoni Gitzler ur. 13 VI 1811 roku na Sląsku w Dobrodzieniu koło Lublińca. Ojciec był dzwonnikiem i szewcem. Pierwsze nauki pobieral Ludwik w miejscowej szkole ludowej. W 1822 roku został zapisany do katolickiego gimnazjum we Wrocławiu 209. Zamieszkal $w$ konwikcie, gdzie jedno miejsce przeznaczone bylo na mocy fundacji dla ucznia z Dobrodzienia. Wcześnie, bo już w 1825 roku zmarła mu matka, a w 1828 roku zmarl ojciec. We Wroclawiu musiał prywatnie uczyć się łaciny i języka niemieckiego, który był dla niego prawie obcy. Po skończeniu gimnazjum na wyraźne życzenie krewnych rozpoiczą w 1830 roku studia na wydziale teologicznym uniwersytetu wroclawskiego ${ }^{210}$. W 1831 roku przeniósł się na wydział prawny. Szczególnie zainteresował się prawem rzymskim. Gdy profesor Witte wyjechał z Wroclawia do Halle, Gitzler przeniósł się na tamtejszy uniwersytet. Na podstawie rozprawy Lex Julia et Papia Poppaea uzyskal w Halle 1835 roku promocje na doktora obojga praw. Wrócił do Wrocławia, tego samego roku uzyskał tytuł prywatnego docenta, potem profesora nadzwyczajnego, a w 1850 roku profesora zwyczajnego. Był pilnym, sumiennym nauczycielem, lubianym

206 Petrani A., Nauka prawa kanonicznego, s. 275-276.

207 Gazeta Kośc. 3/1845/62.

- 208 Katalog Bibliotek: Uniwersytetu Wrocławskiego (dawny), t. 212, s. 85 .

209 S c hult e J. F., Gitzler Ludwig. W: Allg. D. Biogr., t. 49, Leipzig 1904 , s. 370 .

${ }^{210}$ Nowack K G., Schlesisches Schriftsteller-Lexikon, Breslau $1836-1843$, t. 5 . s. 46.

13 - Prawo Kanoniczne 
przez kolegów i studentów. Udział w konkursach urządzanych na uniwersytetach skłonił Gitzlera do pilniejszego zainteresowania się prawem kościelnym, które stało się jego specjalnością. We Wroclawia w 1833 roku otrzymal nagrodę za dobre opracowanie tematu konkursowego pt. Uber die Grundsätze der Bestrafung durch Fahrlässigkeit begangener Verbrechen bei den alten Deutschen, a w Halle za prace konkursową Uber das Wesen der Rechte des nächsten Erben in Veräusserung von Stammgütern ${ }^{211}$. Obok zajęc na uniwersytecie, profesor Gitzler był wiele lat radcą kurialnym, żywo uczestniczył w życiu spoleczno-politycznym, byl wiceprezesem zrzeszenia mającego na celu obronę religijnej i kościelnej wolności. $\mathrm{Z}$ wielką życzliwością odnosit sį̨ do studentów z Górnego Sląska i Wielkopolski. Opiekowal się Towarzystwem literacko-słowiańskim we Wroclawiu ${ }^{212}$, skupiającym studentów z krajów słowiańskich. Zmarł 5 VIII 1888 roku.

Przeprowadzona dnia 25 VIII 1835 roku habilitacja'z prawa cywilnego i kanonicznego uprawniła prywatnego docenta Gitzlera do wykładów tak jednego jak i drugiego przedmiotu. Faktycznie przez pe-wien czas wykladal prawo pruskie, ale głównie zajął się prawem kościelnym. Według zachowanych planów zajęć prawo kanoniczne wykładał 6 godziny tygodniowo. $\mathrm{Z}$ tych 6 godzín tygodniowo $w$ semestrze zimowym 1858/59 poświęcił 1 godzinę na proces konsystorialny, 1 godzine na prawo małżeńskie kościelne i 4 godziny na prawo kanoniczne lącznie $z$ prawem kościelnym katolickim i ewangelickim ${ }^{213}$. Wśród wielu autorów mówiących pochlebnie o dydaktycznej dzialalności Gitzlera najbardziej trafną ocenę podał Kleineidam w słowach „posiadał dobre zdolności nauczania i żelazną pilność" ${ }^{214}$.

Z publikacji kanonistycznych profesora Gitzlera na szczególną uwage zasługują: Handbuch des gemeinen und preussischen Kirchen Eherechts der Katholiken und Evangelischen, 2 Abtheilungen, Breslau 1840/41; De statu ecclesiae catholicae secundum jus borussicum,. Vratislaviae 1852; Geschichte der Quellen des Kirchenrechts. Zum Gebrauch bei den Vorlesungen, Breslau 1855. We wprowadzeniu umieszczonym na początku Handbuch des gemeinen und Preussischen. Kirchenrechts autor podał: ogólne uwagi dotyczące nauki, źródła prawa kościelnego ogólne dla wszystkich wyznań chrześcijańskich i szczególowe dla katolików i ewangelików, oraz historię źródel prawa kościelnego. Żródła omówił chronologicznie dzieląc na 4 okresy: od Chrystusa do Dionizego Ex., od Dionizego do Gracjana, od Gracjana do. Chappuis $\mathrm{i}$ od Chappuis do polowy XIX wieku. W okresie drugim.

${ }^{211} \mathrm{Sch}$ u 1 t e J. F., Gitzler Ludwig, s. 370 .

$212 \mathrm{~A}$ chremowicz E., Z a b ski T., Towarzystwo-literacko-stowianskie, Wroclaw-Warszawa-Kraków-Gdańsk 1973, s. 168-170.

213 Petrani A., Nauka prawa kanonicznego, s. 276.

$214 \mathrm{~K} l$ eineidam E., Die katholisch-theologische Fakultät, s. 59; „er bessas eine gute Lehrgabe und einen eisernen Fleiss". 
i trzecim osobno podal źródla na wschodzie i osobno na zachodzie. Główna część dzieła podzielona została na dwie księgi. Pierwsza księga zawiera kościelne prawo publiczne w stosunkach zewnętrznych do państwa i innych wyznań oraz $w$ stosunkach wewnętrznych. Księga druga obejmuje prawo osobowe i rzeczowe. Ponieważ podręcznik przeznaczony był do użytku katolików i ewangelików, tam gdzie zachodziły różnice $w$ poglądach, naświetlał autor zagadnienie $z$ pozycji katolickiej i ewangelickiej. Prawo małżeńskie stanowiące drugą część dziela, po 12 paragrafach wprowadzenia dzieli się na 4 rozdziały: o zawarciu majżeństwa, o skutkach małżeństwa i stosunkach rodziców do dzieci, o rozwiązaniu małżeństwa, oraz o polożeniu prawnym po separacji małżeńskiej. Do drugiej części dzieła zostało dołączone rozważanie na temat wymuszonego blogosławieństwa małżeństw mieszanych naświetlone ze stanowiska katolickiego. Jest odpowiedź na dwa waźne pytania: co $\mathrm{w}$ sporze o zawieranie malżeństw mieszanych jest sciśle prawne i jakie propozycje są dopuszczalne i godne polecenia do ostatecznego zalatwienia tego zatargu. Części dzieła nie są równomierne. Najwcześniej opublikowane prawo małżeńskie (1840) obejmuje 214 stron, a pierwsza część opublikowana w 1841 roḳu ma 532 strony. Dodatek z 1841 roku ma 68 stron. Autor przy podziale kierowal się treścią. Pracę dedykował profesorom: Laspeyr, Pernice i Witte jako dowód szczerego szacunku ${ }^{215}$. Podręcznik Gitzlera nie jest tak znakomitym dziełem jak praca Waltera czy Phillipsa. Spełnił jednak wielką rolę $w$ kanonistycznym przygotowaniu dużej rzeszy prawników świeckich i duchownych z diecezji wrocławskiej oraz archidiecezji gnieźnieńskiej i poznańskiej. Gitzler był najlepszym kanonistą świeckim na uniwersytecie wrocławskim w XIX wieku ${ }^{216}$. Podawał zagadnienia bezstronnie, strzegąc katolickiej ortodoksji.

Aby wykazać wplyw wrocławskiego śodowiska naukowego na kanonistyczne wykształcenie duchowieństwa archidiecezji gnieźnieńskiej i poznańskiej wystarczy wymienić kilka nazwisk kaplanów, którzy studiowali we Wrocławiu. Ks. Zienkiewicz i ks. Jabczyński słuchali wykładów ks. prof. Pełki, ks. Kidaszewski uczęszczał na zajęcia prowadzone przez ks. prof. Theinera, a ks. Janiszewski i ks. Respądei studiowali, gdy wykłady prawa kanonicznego prowadzili prof. Regenbrecht i prof. Gitzler. Duchowieństwo wielkopolskie umiało odróżní zdrową naukię od skażonej i wiele korzystało ze studiów, chociaż uniwersytet we Wrocławiu'w pierwszej polowie XIX wieku przeżyał rozmaite burze doktrynalne.

Profesor Movers w 1824 roku pisał do władzy duchownej, że „nauka

$215 \mathrm{Gitzl}$ er L., Handbuch des gemeinen und Preussischen Kirchenrechts der Katholiken und Ewangelischen, Breslau 1840/41.

216 Ocena Kleineidama ujęta w słowach, er war kein überragener Kopf" jest krzywdząca; por. Kleineidam E., Die katholisch-theologische Fakultät, s. 59. 
teologii w pośmiewisko przeszla..." i że ,potrzeba wielkiej rezygnacji, by słuchać teologii we Wrocławiu" ${ }^{217}$. Przez teologie rozumiał wszystkie przedmioty wykładane na tym wydziale, więc także i prawo kanoniczne. Nie tylko mlody uniwersytet wrocławski gdzie wiele było katedr nie obsadzonych, ale większość uniwersytetów niemieckich przeżywala na początku XIX stulecia poważne trudności. Główną przyczyną tego zjawiska było przeobrażenie akademii jezuickich na uniwersytety panstwowe i sekularyzacja zakonów. Zakonnicy zajmujący stanowiskia profesorów znaleźli się $w$ nowej sytuacji żyçiowej, która wplywala na ich stosunek do Kościoła, państwa i nauki. Wewnętrzną prężność uniwersytetu wrocławskiego osłabiała postawa ledwie prawowiernego profesora Deresera $i$ nowatorskie wystapienia ks. Theinera i Rongego oraz przylączenie się do nich prof. Regenbrechta $i$ innych. Negatywny wpływ na środowisko uniwersyteckie wywarło stanowisko wobec Kościola, odejście z Wroclawia i przejście ha protestantyzm biskupa Leopolda Sedlnickiego. Dostrzegał i właściwie oceniał te wydarzenia arcybiskup Przyluski. Nie mial bezpośredniego wplywu na uniwersytet wrocławski ani na sąsiednią diecezję. Pozostała mu jednak możliwość odizolowania pewnej części studentów teologii archidiecezji gnieżnieńskiej i poznańskiej od Wrocławia. Przy współpracy $z$ rektorem Janiszewskim rozpoczął wysyłać kleryków na inne uniwersytety pruskie. Do Wrocławia w drugiej polowie XIX wieku wyjeżdżała znikoma ilość maturzystów, którzy na własną rękę zapisywali się na studia teologiczne.

\section{Studia na innych uniwersytetach niemieckich}

Wladza duchowna archidiecezji gnieźnieńskiej i poznańskiej w drugiej połowie XIX wieku najcḩętniej wysyłała swych kleryków na studia uniwersyteckie do Monasteru, Monachium i Fryburga Badeńskiego.

Uniwersytet $w$ Monasterze zostal założony w 1773 roku przez Franciszka Fürstenberga ministra i wikariusza generalnego, który zasłużył się $w$ dziedzinie nauk finansowych, medycznych i szerzeniu szkól ludowych ${ }^{218}$. Był uniwersytetem katolickim i posiadal początkowo wydział teologii katolickiej, filozofii, medycyny i prawa. Gdy wladze panstwowe zmniejszyly dochody, stal się uniwersytetem niepelnym i posiadal tylko dwa wydzialy: teologię katolicką i filozofię ${ }^{219}$. Jednym z profesorów monasterskiej uczelni był Adolf Cappenberg, który kariere profesorską rozpoczął w Poznaniu. Do 1856 roku klerykom archidiecezji gnieźnieńskiej i poznańskiej zaliczano studia w Poznaniı i po jednym roku korzystania $z$ wykładów na uczelni monasterskiej,

217 B rzeziński A., Zywot ks. Kidaszewskiego, s. 41.

218 P i e per A., Münster. W: Kirchl. Handl., t. 3, s. 1057.

\$19 Tyg. Katol., 3/1862/ dod. nr 1, s. 11. 
mogli uzyskać stopień akademicki. Rozporządzenie ministerialne z 1856 roku do uzyskania stopnia akademickiego postawilo warunek wysluchania na uniwersytecie trzechletniego kursu teologii ${ }^{220}$. Wśród studentów akademii monasterskiej pochodzących z archidiecezji gnieznieńskiej i poznańskiej znajdował się Jakub Kiełczyński, Michał Mindak, Jan Korytkowski i Antoni Sucharski221. W 1861 roku w Monasterze studiowało 8 kleryków z Poznania ${ }^{222}$, a $w$ następnym roku na ogólną liczbę 135 kleryków archidiecezji gnieźnieńskiej i poznańskiej, 92 odbywało studia w Poznaniu, $32 \mathrm{w}$ Gnieźnie, a 11 na uniwersytetach $w$ Monasterze, Monachium i Fryburgu. Wśród zdobywających wiedzę teologiczną na uniwersytetach największa grupe liczacą 5 osób stanowili studenci w Monasterze ${ }^{223}$. W 1866 roku było na teologii w Monasterze 8 Polaków ${ }^{224}$. Należy przypuszczać, że wszyscy pochodzili z diecezji gnieźnieńskiej i poznańskiej.

Srodowisko monasterskie nie wydało wybitnych naukowców $w$ dziedzinie teologii czy prawa kanonicznego, ale dzięki swej ortodoksji stało się głównym ośrodkiem życia katolickiego, w drugiej połowie XIX wieku. Tam odbyło się kilkadziesiąt zjazdów różnych korporacji katolickich, w których ucżestniczyli delegaci z Niemiec i sąsiednich krajów. Rezolucje miały za zadanie obronę wolności Kościoła. Na jednym $z$ walnych zjazdów domagano się, by ,wychowaniem duchownyıch z zupelną wolnością kierowali biskupi, jako jurysdykcję też nad mimi bez przeszkód i wyłącznie wykkonywali" ${ }^{225}$. To wszystko bez wątpienia znajdowało oddźwięk w kręgach studenckich i wplywało na kształtowanie właściwych postaw.

Znacznie większe osiągnięcia naukowe w XIX wieku mial uniwersytet $w$ Monachium. Istnial od 1746 roku. Zalożenie swe zawdzięcza hr. Ludwikowi Maksymilianowi Bawarskiemu. Posiadał 5 wydzialów: teologię katolicka, prawo, statystykę, medycynę i filozofię ${ }^{226}$. Monachium przy końcu pierwszej polowy XIX wieku stało się poważnym ośrodkiem życia katolickiego dzięki życzliwości wladz państwowych i aktywności wielu światłych uczonych. Minister Abel zmierzał przekształcić Bawarię na państwo katolickie. Najwięcej do krzewienia ducha katolickiego przyczynily się pisma historyczno-polityczne Phillipsa i Gwidona Görresa. Potem nastawienie kól rządzących zmieniło się. Arcybiskup Przyłuski w 1861 roku skierował do Monachium na

${ }^{220} Z$ Zieliński Z., Kościót katolicki $w$ Wielkim Księstwie Poznańskim, s. 214.

221 AAP, SD 10.

${ }^{222} \mathrm{Z}$ i elíński Z., Kościót katolicki $w$ Wielkim Księstwie Poznańskim, s. 214.

223 Tyg. Kathol. 3/1862/417.

$224 \mathrm{~K}$ ar bow iak A., Mtodziez Pol. akad. za granicq, s. 80.

225 Przegl. Katol. 40/1885/630.

$226 \mathrm{H}$ ip peau M. E., Wychowanie publiczne $w$ Niemczech, s. 152 (numeracja druga). 
studia neoprezbitera Józefa Chorzyńskiego ${ }^{227}$. Liczba studiujących we wspomnianym roku na uniwersytecie monachijskim objęła 3 kleryków $\mathrm{z}$ archidiecezji gnieźnieńskiej i poznańskiej ${ }^{228}$, a w następnym roku powiększyła się o jednego ${ }^{229}$. Często wysylano do Monachium suodiakonów, diakonów, a nawet neoprezbiterów. Tu zaliczano poznańskie studia seminaryjne i w ciagu jednego roku można było uzyskać doktorat ${ }^{230}$. Z uniwersytetem monachijskim związani byli znąkomici kanoniści Ernest de Moy i Jerzy Phillips.

Ernest de Moy ur. 10 VIII 1799 roku w Monachium. Studia uniwersyteckie ukończył $\mathrm{w}$ Monachium i planował poświęcić się karierze polityczno-wojskowej. W roku 1827 zostal prywatnym docentem. Polem otrzymal nadzwyczajną profesure prawa naturalnego i państwowego. Stanowisko profesora zwyczajnego na uniwersytecie w Monachium objął w 1837 roku 281 . Oburzony na gorszące postępowanie króla, razem $z$ innymi wyrazil swe niezadowolenie, co spowodowało $u$ tratę katedry. Na początku 1848 roku wyjechal do Tyrolu i wydawal tam dziennik konserwatywny ${ }^{232}$. Stanowisko profesora objął ponownie w 1851 roku na uniwersytecie w Insbruku, gdzie wykladal prawo niemieckie, kościelne i historię prawa. W 1858 roku został rektorem uniwersytetu. Bardzo aktywnie pracowal w Generalnym Zgromadzeniu Katolików. Zmarł w Insbruku dnia 1 VIII 1867 roku.

Prace z zakresu prawa państwowego Moya odznaczają się dobrym zebraniem materialu, a pisma filozoficzne i polemiczne przede wszystkim opierają się na ideach katolickich. Moy był dobrym kompilatorem. Interesował się najwięcej kościelnym prawem małżeńskim. Napisał $z$ tej dziedziny De impedimentis matrimonii, München 1827; Die Ehe und die Stellung der katholischen Kirche ins Deutschland rücksichtig dieses Punktes ihrer Disciplin. Mit einem Anhang über clas Verhältniss der Kirche zum Staate und einer tabellarischen Ubersicht der in den bedeutenderen deutschen Bundesstaaten aufgestellten Ehegsetze, Landshut 1830; Das Eherecht der Christen in der morgenländischen und abendländischen Kirche bis zur Zeit Karls d. Gr. aus den Quellen dargestellt, Regensburg 1833. Opprócz tego opublikowal: Grundlinien einer Philosophie des Rechtes vom katholischen Standpunkte, Wien 1854-1857 (dwa tomy) i Die weltliche Herrschaft des Papstes und die rechtliche Ordnung in Europa, Regensburg 1860. Rozpoczął wydawać w Insbruku czasopismo poświęcone prawu ka-

227 Tyg. Katol. 2/1861/49.

${ }_{228}$ Zieliński Z., Kościót katolicki $w$ Wielkim Księstwie Poznańskim, s. 214.

${ }_{229}$ Tyg. Katol. 3/1862/417.

${ }_{20}$ Zieliński Z., Kościol katolicki $w$ Wielki Księstwie Poznañskịm, s. 214 .

${ }_{231}$ S c hulte J. F., Kraft Karl Ernst Moy. W: Allg. D. Biogr., t. 22. Leipzig 1885, s. 420.

232 Tyg. Katol. 8/1867/375. 
nonicznemu pt. Archiv für katholisches Kirchenrecht mit besonderer Rücksicht auf Österreich. Pierwszy tom ukazał się w 1857 roku. Sam zredagował 5 pierwszych tomów ${ }^{233}$. Drobne prace zamieszczał na łamach niemieckich i francuskich dzienników 234. Najlepszym dzielem Moya jest wspomniane wyżej Das Eherecht der Christen.... Autor wierny zalożeniom katolickim, starał się podać i udowodnić stanowisko prawa kanonicznego. Zastosował znana i powszechną $w$ tym czasie metodę historyczną, ale nie wykorzystał źródeł wszechstronnie ${ }^{235}$.

Jerzy Phillips ur. 6 I 1804 w Królewcu. Od wiosny 1822 roku do jesieni 1823 roku studiował prawo na uniwersytecie berlinskim, a w roku akademickim 1823/24 w Getyndze. Jego ulubionym profesorem w Berlinie był Savigny, a w Getyndze Eichhorn. Doktorat uzyskal w Getyndze dnia 24 VIII 1824 roku. Habilitację przeprowadzil z niemieckiego prawa na wydziale prawnym uniwersytetu bérlińskiego $w$ 1826 roku 236 . Tam $w$ następnym roku został powołany na stanowisko profesora nadzwyczajnego. Wykłady wygłaszane $z$ pamięci cieszyły się tak wielkim zainteresowaniem, że często brało w nich udział ponad 300 sluchaczy 237. Potem przeniósł się. do Monachium na stanowisko radcy ministerstwa spraw wewnętrznych. $\mathrm{Na}$ wydziale fiIozofii uniwersytetu monachijskiego "wygłaszał odczyty z zakresu historii, a potem kilkanaście lat wykladal na wydziale prawnym. W 1846 roku zostal wybrany na stanowisko rektora uniwersytetu. Następną uczęnią, $w$,której rozpoczął wykłady $w 1850$ roku byl uniwersytet $w$ Würzburgu. Stąd po kilku miesiącach przeniósl się do Insbruku. Z racji zdrowotnych opuścił Insbruk i w 1851 roku objął stanowisko profesora na uniwersytecie w Wiedniu. W latach 1860—1865 korzystał z urlopu planując $w$ tym czasie ukończyć rozpoczęte dzieło Kirchenrecht. Po powrocie z urlopu do końca życia prowadził wykłady. Zmarł we własnej willi w Aigen koło Salzburga dnia 6 VIII 1872 roku.

Dziedziną zainteresowań Phillipsa bylo prawo germańskie, niemieckie i kościelne tak publiczne jak i prywatne oraz historia różnych instytucji. Pierwsze większe dzieło zatytułowane Versuch einer Darstellung des Angelsächsischen Rechts ukonczyl w Getyndze 1825 roku i dedykowal profesorowi Eichhornowi. Praca ta została dobrze przyjęta i otwarła Phillipsowi drogę do kariery naukowej. Wyjazd do Anglii $i$ odwiedziny krewnych połączyl $z$ badaniami nad starożytnością prawa angielskiego. Owocem tego była publikacja pt. Englische

233 Schult e J. F., Moy, s. 421.

231 Tyg, Katol. 8/1867/375.

${ }_{235} \mathrm{~S} c h \mathrm{l}$ Ite J. F., Die Geschichte der Queilen und Literatur des kanonischen Rechts, Stuttgart 1880, t. 3, cz. 1, s. 371.

${ }^{236} \mathrm{~S} \mathrm{chulte}$ J. F., Phillips George. W: Allg. D. Biogr., t. 26, Leipzig 1888 , s. 81 .

237 Tyg. Katol. 13 (1872) 576. 
Reichs ind Rechtsgeschichte seit der Ankunft der Normannen im Jahre 1066 nach Christi Geburt, Berlin $1827^{238}$, która nie została zakończona. Opracowany zostal okres od Wilhelma Zdobywcy do Henryka II, a więc od 1066 do 1189 roku. Również następne dzieło Deutsche Geschichte mit besonderer Rücksicht auf Religion, Recht und Staatsverfassung szeroko rozplanowane nie zostało $w$ całości zrealizowane. Wydano tylko dwa tomy. W pierwszym ujął czasy Merowingów, a w drugim okres karoliński. Autor wykazal, że chrześcijaństwu należy zawdzięczać ustrój ówczesnego państwa: Dzięki nauce chrześcijańskiej papiestwo mogło stać się centralnym ośrodkiem dla spraw kościelnych, a cesarstwo dla świeckich. Wszechstronnie przedstawil prawo Jubliczne i prywatne. Prawu kościelnemu dawal pierwszeństwo nad. prawem państwowym ${ }^{239}$. Dla studentów przygotował podręcznik, który ukazał się w 1845 roku w Monachium i doczekał się kilku wydań. Byl to zarys historii państwa i prawa niemieckiego zatytulowany Deutsche Reichs und Rechtsgeschichte. Za podstawe całego systemu prawnego uważal możność zabezpieczenia porządku wewnętrznego i abronność wobec zewnętrznej agresji. $Z$ tego wyprowadził 3 podstawowe zasady prawa niemieckiego: die Freiheit, Gewehre, Vormundschaft. Dzieło zawieralo wiele trafnych spostrzeżeń, ale nie górowalo nad pozycjami wydanymi na ten temat $w$ XIX wieku. Niektóre poglądy wydają się być nieco przestarzałe.

Do większych sukcesów niż w prawie państwowym, doszedł Phillips. w dziedzinie badań prawa kościelnego. Na szczególną uwagę zasługują: Der Codex Salisburgensis, Die Diözesansynode, a przede wszystkim Kirchenrecht. Kodeks salisburski jest artykulem naukowym $z$ historii źródel prawa okresu przedgracjańskiego. Powodem wydania: Synodu diecezjalnego byly żądania pewnych kręgów duchowieństwa wypowiadane po 1848 roku. Autor przeciwstawil się wysuwanym postulatom nie wnosząc świeżych myśli, arti nowego materiału 240. Przyczynił się jednak w dużej mierze do uspokojenia wzburzonych umysłów. Nad dzielem Kirchenrecht pracowal blisko 30 lat. Pierwszy tom ukazal się w Regensburgu 1845 roku. Phillips dal doskonalsze dzieło niż Sauter, Brendel, Droste-Hülshoff, Barth czy Gitzler. Materiał podzielił wg własnych przemyślen, a $w$ jasnym wykładzie przedstawił zagadnienia wszechstronnie i przekonywująco. Scisłość naukowa nie zmniejszyła żywości przekazu ${ }^{241}$. Praca wydana w latach 1845-1875 osiaggnęla 7 tomów. Jak $w$ prawie państwowym, tak $\mathrm{i} w$ kościelnym podał fundament całego systemu prawnego. Chrystus jako głowa Kościoła jest centralnym punktem spoleczności chrześcijańskiej. On po-

238 Tyg: Katol. 13 (1872) 576 błędnie podaje Getynge jako miejsce wydania tego dzieła.

$239 \mathrm{~S}$ ch u l t e J. F., Phillips, s. 83.

$240 \mathrm{~S}$ chult e J. F., Prillips, s. 84.

241 Przegl. Pozn. 1 (1845) 331-332. 
siada najwyższą władzę królewską, nauczycielską i kapłańską. Kościól Jego królestwem, podmiotem nauczania i Jego świątynią ${ }^{242}$. W opracowaniu poszczególnych kwestii stawiał na początku zasady, przeprowadzał zastosowanie w ciągu dziejów, a na końcu omawiał aktualne przepisy. Przy pierwszym wykorzystywał najczęściej chrześcijańską nau'ke, w drugim pomagały mu gruntowne badania historyczne, a w trzecim uwidaczniały się wrodzone uzdolnienia do jasnego precyzowania myśli 243. „Prawo kościelne” Phillipsa pomoglo w ugruntowaniu pozycji Kościoła katolickiego w Niemczech i w tym leży jego wielka zasługa. Dzięki temu z szacunkiem i wdzięcznością odnosił się do niego Rzym, którego oczy od dawna zwrócone byly na młodego konwertytę. Przesadną ocenę wielkości i zasług Phillipsa dał "Tygodnik Katolicki" we wspomnieniu pośmiertnym ${ }^{24 t}$. Można jednak z tego wnioskować, jak wielkim autorytetem cieszył się wśród kapłanów archidiecezji gnieźnieńskiej i poznańskiej, którzy byli czytelnikami tego pisma. Phillips nie rozwinął prawa kanonicznego naukowo ani w zakresie metody, arti w opracowaniu szczególowych zagadnień. Duża natomiast mają wartość badania historyczne przeprowadzone $w$ gruntowny sposób ${ }^{245}$. Ponieważ Kirchenrecht było do pewnego stopnia zbiorem tematycznie ułożonych ekscerptów i uważane było niejednokrotnie za dzieło mające na celu duchowe zbudowanie, wydał Phillips pod koniec życia Lehrbuch des Kirchenrecht. Było to kompendium prawa kanonicznego, w którym pominął materiał nie związany ściśle $z$ tą dyscypliną ${ }^{246}$.

Obok wspomnianych już uniwersytetów, klerycy archidiecezji gnieźnieńskiej i poznańskiej wyjeżdżali na studia do Fryburga Badeńskiego. Wysyłanie kleryków zainicjował ks. Jakub Prabucki, który pochodzil z Pomorza, a w latach 1842-1846 byl dyrektorem gimnazjum św. Marii Magdaleny w Poznaniu 247. Uniwersytet we Fryburgu założony został $\mathrm{w}$ polowie XV wieku ${ }^{248}$, potem przechodzil reorganizacje w 1537 i 1697 roku ${ }^{249}$. Posiadał 4 wydziały: teologię katolicka, medycynę, prawo i filozofię. Wydarzenia polityczne, trudności jakie przeżywał Kościół w pierwszych dziesiątkach XIX wieku wpłynęły ujemnie na wydział teologiczny uniwersytetu fryburskiego. Część profesorów głosiła niepewną naukę wybierając pośrednią drogę między

${ }^{242} \mathrm{~S}$ c hulte J. F., Phillips, s. 84.

243 Przegl Pozn. 1 (1845) 333.

244 Tyg. Katol. 13 (1872) 577; „Kirchenrecht ...stało się głównym zadaniem jego życia i którego obszerność pozostawia wątpliwości, czy Phillips jako prawnik lub teolog większego uwielbienia godzien". 245 S chult e J. F., Phillips, s. 85.

246 Tyg. Katol. 12 (1871) 654. pis).

${ }^{247}$ Glemp J., Rektorzy seminarium duchownego, s. 358-359 (przy-

${ }_{248}$ Fryburg. W: Encyklopedia kościelna Nowodworskiego, t. 5, War-szawa 1874 , s. 643 .

${ }_{249} \mathrm{H}$ i p pea u M. E., Wychowanie publiczne $w$ Niemczech, s. 164. 
doktryną katolicką, a protestancką. Prof. Reuchlin porzucil kaplaństwo i objął stanowisko profesora na protestanckim uniwersytecie $\mathrm{w}$ Heidelbergu, Schreiber przyłączyl się do sekty Rongego, Meier był członkiem potępionej przez Kościół Rady Kościelnej. Prawo kanoniczne wykładał prof. Amman, który nie mógł przekazać zdrowej nauki katolickiej, ani poszanowania prawnego porządku Kościola, skoro na publicznych zebraniach nazywał papieża rzymskim sułtanem. Zmarł w halucynacjach obłąkania, żywiąc nienawiść do Kościoła katolickiego 250. Ożywienie ducha nastąpiło $z$ chwilą powolania na stanowisko profesora teologii dogmatycznej Staudenmeiera, a dla teologii moralnej Hirschera, który opieral się na pier,wszych źródłach nauki katolickiej, bo wydawało mu się, że nawet scholastyka może być już nadpsuta ${ }^{251}$. Historię Kościoła objął prof. Vogel, a teologię pasterską prof. Werk. W roku akademickim 1862/63 uniwersytet fryburski posiadał blisko 300 studentów. Na teologii studiowało wtedy 158 osób ${ }^{252}$, wśród których znajdowało się 2 kleryków z archidiecezji gnieźnieńskiej i poznańskiej 253. Prawo kanoniczne wykładal prof. Buss związany z uniwersytetem od 1833 roku.

Franciszek Józef Buss (1803-1878) przeprowadził habilitację we Fryburgu, w 1833 roku objął stanowisko profesora nadzwyczajnego, a trzy lata później profesora zwyczajnego. Uczył prawie do końca życia. Był posłem w badeńskim Landtagu. Bronil tam wolności i riezawisłości Kościoła ${ }^{254}$. W związku z konkordatem Księstwa Badeńskiego ze Stolica Apostolską solidaryzował się z grupą, która przyznawała Kościołowi prawo nadzoru nad wychowaniem młodzieży katolickiej i nauczaniem religii ${ }^{255}$.

Głównym dziełem kanonistycznym Bussa jest Methodologie des Kirchenrechts wydana we Fryburgu 1842 roku. Idąc w niej za szkoka historyczną i jej głównym przedstawicielem Savigny'm przyznał prawu kościelnemu oddzielne miejsce obok prawa publicznego i prawa prywatnego. Widzial jego specyfikę genetyczną i aktualną, gdyż związki religijne powstawały i moga powstawać poza państwem, a często nawet wbrew jego woli. $Z$ samej natury rzeczy wytwarzają własne normy prawne, które zasługują na poszanowanie ${ }^{250}$. Autor wiele miejsca poświęcil organicznemu systematyzowaniu, ale nie okazał grun-

250 Przegl. Pozn. 21 (1855) 590.

$251 \mathrm{~K}$ ozlowski F., Charakterystyka wydzialu teologicznego katolickiego $w$ Freibergu badeńskim, Gazeta Kośc. 4 (1846) 112-117.

252 Fryburg. W: Encyklopedia kościelna Nowodworskiego, t. 5, Warszawa 1874 , s. 643 .

253 Tyg. Katol. 3 (1862) 417.

${ }^{25 s} \mathrm{~S}$ c hult e J. F., Buss Franz Josef. W: Allg. D. Biogr., t. 47, Leipzig 1903 , s. 408.

255 Przegl. Pozn. 31 (1861) 50.

$250 \mathrm{Halban}$ L., Kilka uwag dotyczacych znaczenia naukowego $i$ praktycznego prawa kościelnego, Lublin 1957, s. 27. 
townej znajomości źródel ${ }^{257}$. Oprócz tego dzieła wydał Urkundliche Geschichte des National - und Territorial - Kirchenthums in der kath. Kirche Deutschlands, Corp. jur. ecc, germ., Die Gesellschaft Jesu, ihr Zweck, ihre Satzungen, Geschichte, Aufhebung und Stellung in Gegenwart, Die Wiederherstellung des canonischen Rechts in der oberheinischen Kirchenprowinz, Die kirchliche Immunität. Rozpoczą wydawać czasopismo Capistran mające za przedmiot prawo i interesy niemieckich katolików. Wyszedł tylko jeden zeszyt w 1847 roku ${ }^{258}$. Prace swoje wydawal również $w$ przekładach na inne języki. Niektóre przekłady są jego wylącznym dziełem, a część zlecał innym osobom, czuwając nad ich wiernością. Mial szeroko zakrojone plany naukowe i posiadal wszechstronną wiedze, ale ze względu na wrodzoną szybkość nie mógl zdobyć się na wypracowanie spokojnej i uporządkowanej całości. Dzieła jego są jakby niedomknięte i dlatego nie dały trwałych wyników ${ }^{259}$. Buss był czlowiekiem bardzo prac.switym. To zamiłowanie do pracy naukowej i podejmowania szerokiej działalności społecznej przekazywał studentom.

Możliwość przechodzenia z jednej uczelni na druga i latwość publikowania rozpraw dawały sposobność do korzystania z wiedzy innych ośrodków naukowych działających na terenie Niemiec. $Z$ tej racji wypada przynajmniej poświęcić nieco miejsca prof. Walterowi, którego wykładów $w$ Bonn sluchali studenci $z$ archidiecezji gnieźnieńskiej i poznańskiej. Podręcznikiem Waltera posługiwano sie nie tylko w Poznaniu, ale również $w$ innych seminariach polskich.

Ferdynand Walter (1794-1879) od jesieni 1814 roku studiowal na uniwersytecie w Heidelbergu. Tu otrzymał dnia 10 VIII 1818 roku stopień doktora prawa. Wnet przeprowadzil habilitację i jako prywatny docent rozpocząl pracę dydaktyczną w 1819 roku na uniwersytecie w Bonn. Cale swoje życie związał $z$ tą uczelnią. W latach 1848-1850 brał czynny udział w życiu politycznym jako czlonek pierwszej izby parlamentarnej. W ostatnich latach życia prawie calkowicie utracil wzrok.

Na uniwersytecie wykładał początkowo "Pandekta”, a potem do 1836 roku francuskie prawo cywilne. Obok tych przedmiotów był profesorem encyklopedii prawa, historii prawa rzymskiego, prawa kościelnego, prawa naturalnego, prawa międzynarodowego, historii prawa niemieckiego i niemieckiego prawa prywatnego. Dzięki usystematyzowaniu życia, wielkiej pracowitości i odpowiedzialności za powierzone obowiązki Walter przygotowal podręczniki prawie do wszystkich przez siebie wykładanych przedmiotów. Najwcześniej wydał podręcznik prawa kościelnego, potem niemieckie prawo prywatne, encyklopedię prawnicza, historię prawa niemieckiego i historię prawa rzym-

257 Przegl. Pozn. 1 (1845) 332.

$258 \mathrm{Schu} 1 \mathrm{t}$ e J. F., Buss, s. 409.

259 Schulte J. F., Die Geschichte der Quellen, t. 3, cz. 1, s. 393. 
skiego. Zebral z dawnych publikacji i wydal „Corpus juris germanici". Bardizo interesujące i wartościowe sa jego dziela: Naturrecht und Politik, Das Alte Wales, Das alte Erzstift Köln ${ }^{260}$.

Lehrbuch des Kirchenrechts mit Berücksichtigung der neuesten Verhältnisse, Bonn 1822, jest wierną kopią dzieła Sautera, które Walter oczyścił'z gallikanizmu ${ }^{261}$. Począwszy od czwartego wydania, dzieło to wychodzilo pod nieco zmienionym tytulem: Lehrbuch des Kirchenrechts aller christlichen Konfessionen. Osiągnęlo aż 14 wydań. Późniejsze wydania były dwa razy obszerniejsze od pierwszego. Osme wydanie zostało przetlumaczone na język francuski i hiszpański, a dziewiąte na język włoski. Podręcznik w języku francuskim ukazał się w Paryżu w 1841 roku ${ }^{262}$. Wydania różnią się między sobą. Czwarte i siódme wydanie jest jakby nowa praca, a dziewiąte i jedenaste uległo dalszym zmianom. Do wydania siódmego wykorzystał autor konstytucję Benedykta XIV De synodo dioecesana, do której rzadko kanoniści niemieccy siegali ${ }^{263}$. W przedmowie do dwunastego wydania zamieszczona została historia powstania $i$ rozpowszechniania tego podręznika oraz opis politycznego stanu Kościoła na ziemiach niemieckich po 1848 roku. Do wydania trzynastego dołączony zostak nowy rozdział o źródłach prawa kanonicznego. W tym wydaniu również zostalo przedstawione prawo kościelne poszczególnych krajów: Anglii, Holandii, Norwegii i Polski. Materiały dotyczące polskieg. prawa kościelnego otrzymal Walter od prof. Romualda Hube z Petersburga. Ostatnie, czternaste wydanie na prośbę ociemniałego już wtiedy autora przygotowal $\mathrm{i}$ wydal drukilem w roku 1871 dr Hermann Gerlach.

Prof. Walter posiadal dużą znajomość prawa rzymskiego, którą wykorzystal przy pisaniu Lehrbuch des Kirchenrechts. Po przedstawieniu źródel układał material wg podziału instytucji Justyniana ${ }^{264}$. Zawsze cechowała go życzliwość i uległość w stosunku do najwyższego autorytetu nauczycielskiego Kościoła. Przed rozpoczęciem soboru watykańskiego I przedstawił anonimowo propozycję reformy kościelnej w zakresie prawa małżeńskiego, nieomylności i władzy papieża ${ }^{265}$. Chociaż postulatów nie uwzględniono, calkowicie zgodził się $\mathrm{z}$ wynikami soboru.

Studia na uniwersytetach niemieckich dawały duchowieństwu archidiecezji gnieźnieńskiej i poznańskiej odpowiedni zasób wiedzy prawniczej. Zakres wiedzy określały podręczniki wydawane przez profeso-

${ }^{260} \mathrm{Sch}$ hulte J. F., Walter F. W: Allg. D. Biogr., t. 41, Leipzig 1896, s. 23.

${ }_{261}$ Petrani A., Nauka prawa kanonicznego, s. 240.

262 Przegl. Pozn. 1 (1845) 331.

263 Petrani A., Nauka prawa kanonicznego, s. 86.

264 Przegl. Pozn. 1 (1845) 332.

265 Das allgemeine Concilium und Weltage, Regensburg-Mainz 1869;

Uber die kirchliche Unfehlbarkeit, Bonn 1871. 
rów. Najwięcej $w$ tej dziedzinie zrobił Walter, który dal do rąk studentów podręczniki prawie do wszystkich wykładanych przez siebie przedmiotów. Phillips pod koniec życia skrócił abszerne dzieło Kirchenrecht dając kompendium prawa kanonicznego. Inni wyraźnie zaznaczali, że publikacja jest zbiorem wykładów ${ }^{266}$. W ramy wykładów práwa kanonicznego wchodziły zagadnienia $z$ filozofii i teologii prawa. Poważnie traktowano zapoznanie istudentów ze źródlami prawa kościelnego oraz obowiązującym prawem osobowym i rzeczowym. $Z$ prawa rzeczowego najwięcej czasu poświęcano prawu małżeńskiemu i majątkowemu. Mniejszą uwage zwracano na kocielne prawo procesowe $\mathrm{i}$ prawo karne. $\mathrm{Z}$ dziedziny prawa publicznego podawano nie tylko podstawowe zasady prawne normujące stosunek Kościola do państwa, ale wykładano obowiązujące przepisy prawne wydane przez państwo w sprawach kościelnych.

Wykłady i naukowe publikacje, z którymi spotykali się studenci w bibliotekach uniwersyteckich, uczyly sposobu ujmowania zagadnień i korzystania ze źródeł i literatury. Praca twórcza profesorów stanowiła podniete do podejmowania pióra w celu naukowego naświetlenia zagadnień aktualnych lub $w$ obronie zagrożonej wolności Kościola. Prawie wszyscy autorzy publikacji kanonistycznych licznie wydawanych na terenie archidiecezji gnieźnieńskiej i poznańskiej studiowali na uniwersytetach, gdzie zdobyli do tego należyte przygotowanie.

\section{Możliwości prywatnego pogłębiania wiedzy kanonistycznej}

Po ukończeniu studiów i otrzymaniu święceń kapłańskich niemal wszyscy neoprezbiterzy kierowani byli przez władzę duchowną do pracy duszpasterskiej, gdzie mieli możność korzystania z części wiadomości zdobytych $w$ seminariach, czy na uniwersytetach. Najbaraziej uźytecznymi dla młodych kapłanów okazywały się traktaty, które omawialy zagadnienia sakramentu pokuty i małżeństwa. Starsi kaplani z racji stanowiska praboszcza $i$ związanego $z$ nim zarządu beneficium, musieli stosować odpowiednie przepisy kościelne i państwowe $z$ zakresu prawa majątkowego. Inne działy prawa kościelnego w praktyce duszpasterskiej znajdowaly mniejsze zastosowanie i stạd Kaplani narażeni byli na zapomnienie tego co zdobyli podczas studiów. Aby uchronic duszpasterzy przed wyjałowieniem umyslów, przepisy kościelne nakazywały egzaminy dla uzyskania jurysdykcji i egzaminy na benificja proboszczowskie. Do tych egzaminów musieli się sami prywatnie przygotowywać, bez pomocy profesorów.

Egzaminy odbywały się przed mianowanymi przez ordynariusza egzaminatorami synodalnymi lub prosynodalnymi, których ustanowienia

${ }^{266}$ Par. Gitzl e r L., Geschichte der Quellen des Kirchenrechts. Zum Gebrauch bei den Vorlesungen, Breslau 1855. 
domagal się Sobór Trydencki ${ }^{267}$. Dla otrzymania tzw. instrumentum iurisdictionis, młodzi kapłani obowiązani byli składać egzamin w każdym roku do chwili uzyskania beneficium parafialnego. Termin egzaminu w archidiecezji gnieźnieńskiej i poznańskiej wyznaczał konsystorz. Gdy zaszła uzasadniona przeszkoda uniemożliwiająca dojazd do Poznania, konsystorz zezwalał od czasu do czasu na egzamin przed własnym dziekanem, który wystawiał odpowiednie świadectwo ${ }^{268}$. Egzaminowany musiał wykazać odpowiednie wiadomości z teologii dogmatycznej, moralnej i prawa kanonicznego potrzebne $w$ konfesjonale. Podstawowym zagadnieniem $z$ prawa kanonicznego, to jurysdykeja ogólnie oraz szczególowo $w$ odniesieniu do rezerwatów i kar kościelnych.

Trudniejszy był egzamin dla uzyskania beneficium proboszczowskiego. Początkowo egzaminy te odbywały się $w$ różnych terminach, na każde wakujące probostwo. Ponieważ było to bardzo niewygodne, arcybiskup Przyluski postanowil, że świadectwo egzaminu zachowuje ważność w okresie 6 lat i uprawnia do starania się o wakujące w tym czasie probostwa. Egzamin odbywał się podczas letnich ferii w dniu ustalonym przez konsystorz. Na prace pisemne przeznaczano 4 godziny przed południem (g. 8-12), a egzamin ustny przeprowadzano po południu od godziny 15. Opracowywanie tematów pisemnych odbywało się pod nadzorem. Nie wolno było komunikować się $z$ obecnymi na sali, ani wychodzić na zewnątrz. Na piśmie opracowywano wyznaczone zagadnienia z Pisma św. i dekretów Soboru Trydenckiego. Egzamin ustny obejmowal. całą teologie, prawo kanoniczne, historię Kościola $i$ inne dyscypliny wykłaldane w czasie studiów teologicznych ${ }^{269}$.

Oprócz egzaminów, które w sposób urzędowy skłaniały do pówtarzania i pogłębiania wcześniej zdobytych wiadomości kanonistycznych, istniały inne formy wpływające zachęcająco do zajmowania się tą dyscypliną. W rodzaju inspiracji oddziaływały na duchowienstwo kongregacje dziekanów, konferencje dekanalne i rekolekcje kapłańskie.

Owoena działalność synodalna zanikła $w$ Polsce $w$ XVIII wieku. W następnym stuleciu nie odbył się na ziemiach polskich żaden synod diecezjalny. Nie sprzyjało temu rozbicie narodowe i skrępowanie Kościoła przez rządy zaborcze. Arcybiskup Ledóchowiski doceniając wartość oddziaływania synodów na duchowieństwo i wiernych, rozpocząl zwoływać kongregacje księży dziekanów, które tak w.formie jak i $w$ treści posiadały charakter bardzo zbliżony do synodów. W latach $1866-1872$ odbylo się 6 kongregacji. Miejscem zebrań były na przemian stolice archidiecezji Gniezno i Poznań. Uczestniczyli $w$ nich dziekani, prodziekani, członkowie kapituł metropolitalnych, radcy kurii i profesorowie seminarium. Kongregacje odbywały się co

${ }^{267}$ Conc. Trid. sess. XXIV, c. 18 de ref.

268 AAP, Personalia ks. Echausta J., KA 208.

269 Tyg. Katol. 3 (1862) 458-459. 
roku w ostatnią Środę sierpnia. Odpowiednie propozycje dotyczące. tematu i rozwiązania zagadnień należało składać na piśmie arcybiskupowi przynajmniej miesiąc przed terminem. Dekrety wydane przez arcybiskupa na kongregacji miały moc obowiązującego prawa diecezjalnego ${ }^{270}$. Podawano je do wiadomości duchowieństwa przez dziekanów, przez konsystorze i ogłaszano drukiem ${ }^{271} \mathrm{w}$ formie oddzielnych broszur lub w czasopismach katolickich.

Ponieważ owocem kongregacji są dekrety ściśle prawne, dekrety dotyczące liturgii $i$ instrukcje zawierające polecenia duszpasterskie lub wyjaśnienia, wypada zwrócić uwagę na te, które posiadają związek $z$, ogólnym prawem kościelnym, pomijając przepisy liturgiczne. Pierwsza kongregacja jako pewne novum w życiu Kościola, miała charakter ogólny. Na drugiej w 1867 roku ogłoszono dekret o wizytacji kościolów parafialnych przez dziekanów, o administrowaniu sakramentów, o tonsurze i stroju duchownych ${ }^{272}$. W następnych latach regulowano dekretami sprawę dopuszczania dzieci do pierwszej: Komunii św., erekcji bractw wstrzemięźliwości, oddzielnego miejsca do grzebania nie ochrzczonych dzieci i innych pozbawionych pogrzebu kościelnego ${ }^{273}$, zawierania małżeństw mieszanych ${ }^{274}$, legatów ${ }^{275}$, kaplanów obciążonych długami i aprobaty do sluchania spowiedzi wiernych 276 .

Jedynym ustawodawca na kongregacji był ordynariusz, ale dekrety braly swój początek $\mathrm{z}$ zapytań kierowanych do arcybiskupa, wysuwanych wniosków i dyskasji. Nie tylko postawienie wniosku, ale zabranie glosu $w$ dyskusji a nawet zapytanie zobowiązywało do głębszego zastanowienia się nad zagadnieniem. Często musiało je poprzedzić przeczytanie publikacji na dany temat lub rozmowa w kręgu najbliższych. Kongregacje dziekanów nie tylko mobilizowały najbliższych współpracowników arcybiskupa do studiów na temat aktualnysh zagadnień prawnych, ale inspirowały dołtego ogół duchowieństwa archidiecezji gnieźnieńsikiej i poznańskiej.

Jeden raz $w$ roku zbierali się kaplani poszczególnych dekanatów pod przewodnictwem swego dziekana dla omówienia bieżących spraw kościelnych. Na określenie tego zjazdu używano dwóch terminów

${ }^{270} \mathrm{~L}$ edóchowski M., Acta primae congregationis decanorum habitae die 21 Augusti 1866, Gniezno 1866.

$271 \mathrm{~N}$ o w a cki J., Archidiecezja poznańska, s. 284.

$272 \mathrm{~L}$ ed ó c h.o w S k i M., Acta secundae congregationis decanorum habitae Gnesnae die 28 Augusti 1867, Posnaniae 1867.

${ }^{273} \mathrm{~L}$ edó chowski M., Acta tertiae congregationis decanorum ha-

bitae Gnesnae die 26 Augusti 1868, Posnaniae 1868.

${ }^{274} \mathrm{~L}$ ed ó ch o w s k i M., Acta quartae congregationis decanorum ha-

bitae Gnesnae die 25 Augusti 1869, Posnaniae 1869.

${ }^{275} \mathrm{Le} \cdot \mathrm{d}$ c ch ow s k i M., Acta quintae congregationis decanorum ha-

bitae Gnesnae die 30 Augusti 1871, Posnaniae 1871.

${ }^{276} \mathrm{~L}$ edóchowski M., Acta sextae congregationis decanorum habitae Gnesnae die 28 Augusti 1872, Posnaniae 187.2. 
wymiennie kongregacja lub konferencja ${ }^{277}$. Oprócz wspólnego udziału we Mszy św., czytania Pastoralnej kardynała Maciejowskiego, uchwal 'synodalnych i załatwiania innych spraw, niektórzy dziekani zachęceni widocznie przez arcybiskupa Dunina włączali do programu konferencji wygłaszanie referatów tematycznie związanych z prara duszpasterską opartych na wiedzy teologicznej i kanonistycznej. Podczas konferencji dekanatu kostrzyńskiego dnia 3 X 1837 roku odczytano 3 referaty. W języku polskim wygłasił referat ks. Cwojdziński O towarzystwie wstrzemięźliwości $i$ jego korzyściach, a ks. Gnietczyński $\mathrm{O}$ obowiazkach plebana rozpoczynajacego swe urzędowanie. Po lacinie $O$ sakramencie chrztu wygłosil referat ks. Bodziański. W Srodzie Wlpl. dnia 12 XII 1837 roku przemawiał dziekan Rybicki O obowiazkach pasterzy dusz ${ }^{278}$.

Arcybiskup Dunin zwyczaj wygłaszania referatów na konferencjach dekanalnych upowszechnił przez zarządzenie wydane drukiem dnia 21 I 1841 roku ${ }^{279}$. Nakazal, by dziekan na każdą konferencję wyznaczył referentów, którzy wygłoszą prace naukowe $z$ dziedziny teologicznej, prawniczej i pasterskiej. Zarządzenie weszło $w$ życie, a jako przykład posłużyć może sprawozdanie z przebiegu konferencji dekanalnej odbytej dnia $26 \times 1845$ roku pod przewodnictwem ks. Kalinowskiego dziekana gniewkowskiego. Zgromadzenie zagaił miejscowy dziekan mową na temat Jak praca okoto zbawienia dusz wiernych $i$ nauka maja byc ozdoba każdego kaptana. Kazanie O obowiazkach pasterkich wyglosil ks. Knast z Ostrowa, referat $O$ sakramencie Eucharystii, pokuty $i$ malżenstwie odczytal ks. Rosiński proboszcz Brudni 280

W XIX wieku konferencje dekanalne zmieniały swój charakter. Zanikały pełne grozy spotkania $z$ władzą biskupa reprezentowana przez dziekana podczas których przeglądano przywiezione księgi, parafialne, sprawdzano dokumenty jurysdykcyjne, napiętnowano wykroczenia, a nawet o ważniejszych wykroczeniach dostrzeżonych na konferencji powiadamiano władzę diecezjalną ${ }^{281}$. Ich miejsce zajmowały zgromadzenia nacechowane życzliwością, które miały na celu pogłębienie moralne i intelektualne kaplanów pracującyćh $w$ duszpasterstwie oraz obudzenie szerszych zainteresowań nauką odkładaną niekiedy na dalszy plan $z$ racji klopotów związanych $z$ administracja majątkiem beneficjalnym. Tak $w$ zagajeniach jak $w$ kazaniach $i$ referatach nie oddzielano dyscyplin na wzór podziału wykładów seminaryjnych. Tematy opracowywano $w$ oparciu o nauke teologii, prawa kościelnego i wiązano z życiem. Nie sprzyjało to szczególowemu rozwijaniu zagadnień, ale jaśniej ukazywało powiązania prawa kościelnego z teologią,

277 W a s i a k K., Dziekani archidiecezji poznańskiej, Lublin 1964, mászynopis, AAP, MPS 103, s. 65.

278 Archiwum Teol. 2 (1837) 528-529.

279 Ordinatio Congregationum Decanalium, Poznań 1841.

280 Gazeta Kośc. 3 (1845) 363.

.281 Por. Now a ck i J., Archidiecezja poznańska, s. 333. 
w której ustawy kościelne mają swój fundament. Przygotowanie referatu, wysłuchanie, dyskusja i zapytania mobilizowały referentów do dalszego prywatnego pogłębiania wiedzy teologicznej i kanonicznej.

W budzeniu i podtrzymywaniu zainteresowań nau'kowych duchowieństwa odegrały pewną rolę rekolekcje kapłańskie. Blisko 70 lat zapomniano o ich znaczeniu dla życia kapłańskiego i korzyściach płynących dla pracy duszpasterskiej. Przyczyną tego były rozbiory Polski, wojny, kasata zakonów, reorganizacja diecezji, zatargi z rządami zaborczymi i mała liczba duchowieństwa. Ostatnim biskupem poznańskim, który nakazywal te ćwiczenia duchowne był Antoni Onufry Okęcki ${ }^{282}$.

Gdy nastąpiła pewna stabilizacja życia kościelnego, o rekolekcjach kaplańskich pomyślal dziekan dekanatu krobskiego ks. Franciszek Stefanowicz i znalazł gorących orędowników w osobach ks. Jana Respądka profesora seminarium poznańskiego ${ }^{283}$, Jana Koźmiana redaktora Przeglądu Poznańskiego i ks. Aleksego Prusinowskiego redaktora Tygodnika Katolickiego. Rekolekcje urządzano w Gnieźnie, Poznaniu i Gostyniu. Trwały one dość długo, a odbywały się w czasie letnich ferii kleryckich. W 1864 roku w obu archidiecezjach skorzystało z rekolekcji 49 księży ${ }^{284}$. Przed rozpoczęciem i po zakończeniu ćwiczeń duchownych kaplani mieli możność wymiany poglądów. W naukach rekolekcyjnych uwzględniano zagadnienie obowiązków dobrego pasterza, a wśród czytania duchownego byl temat $O$ obowiqzku kaplana oddawania się naukom ${ }^{286}$.

Poznań stawal się ośrodkiem życia naukowego, a kapłani poznańscy nie tylko $w$ formie zorganizowanej dążyli do pogłębienia wiedzy, ale wykorzystywali do tego również spotkania prywatne. Od 1861 roku księża pracujący w tym mieście urządzali spotkania o charakterze towarzyskim, na których omawiano wychodzące z druku książki, poruszano aktualne zagadnienia duszpasterskie i $w$ ramach braterskiej życzliwości służono sobie wzajemną radą. Na zebrania przybywali proboszczowie, profesorowie seminarium i młodsi księża ${ }^{286}$. Zwyczaj utrwalił się $\mathrm{i} w$ następnych latach odbywały się spotkania prawie w każdym tygodniu ${ }^{287}$, służąc rozwijaniu szlachetnych zainteresowań.

Na rozwój nauki w całej Polsce wywieral wpływ od początku istnienia uniwersytet krakowski. W katedralnej szkole poznańskiej uczy-

${ }^{282} \mathrm{Z}$ ieliński Z., Kościól katolicki w Wielkim Księstwie Poznańskim, s. 230.

${ }^{283} \mathrm{~W}$ tym duchu wydał ks. R es pądek J. broszurkę Odpowiedź xiędza profesora Respadka na list $x$ dziekana Stefanowicza $z$ dnia 28 grudnia 1850 roku zawierajacy uwiadomienie o uchwale ćwiczeń duchownych, zaprowadzonych między Duchowieństwo Dekanatu Krobskiego, Poznań 1851.

${ }^{284} \mathrm{Z}$ i eliński Z., Kościól katolicki $w$ Wielkim Księstwie Poznańskim, s. 233.

${ }^{285}$ Tyg. Katol. 5 (1864) 420.

286 Tyg. Katol. 2 (1861) 345.

287 Pamiętnik Religijno-Moralny ser. II, t. 10 (1962) $216-217$.

14 - Prawo Kanoniczne 
ło wielu sławnych profesorów, którzy przybyli z Krakowa. Jeszcze ściślejsze związanie Poznania z centrum nauki polskiej nastąpiło na: początku XVII wieku, gdy wznowiono działalność Akademii Lubrańskiego. Mimo likwidacji Akademii Lubrańskiego w 1780 roku i trudności w swobodnym komunikowaniu się z Krakowem spowodowanych rozbiorami Polski, uniwersytet krakowski nadal oddziaływal na duchowieństwo wielkopolskie. Przez długie lata należal do powstałego w 1816 roku Towarzystwa Naukowego z Uniweisytetem Jagiellońskim złączonego, które dawało możliwości poglębiania wiedzy, ks. Jan Nepomucen Jabczyński. Został przyjęty na członka honorowego przes: 1847 rokiem ${ }^{288}$. Wymagane pismo polecające musiało najprawdopodobniej zawierać zasługi, które kandydat posiadał w zakresie uprawianir nauki jako takiej i szerzeniu oświaty przez wydawanie Archiwum Teologicznego i Gazety Kościelnej. Towarzystwo przyjęło rozprawę ks. Jabczyńskiego Wiadomość o synodach prowincyonalnych polskich $\dot{\varepsilon}$ zbiorach ich statutów i opublikowało na lamach swego naukowego czasopisma 289.

Gdy usilne starania Augusta Cieszkowskiego i Koła Polskiego w sejmie pruskim nie doprowadziły do założenia polskiego uniwersytetu $w$ Poznaniu, podjęto decyzje zespolenia polskiego ruchu naukowego na wzór towarzystwa warszawskiego lub czeskiej Maticy. Na zebraniu konstytucyjnym dnia 12 I 1857 roku przyjęto statut wzorowany na statucie Warszawskiego Towarzystwa Przyjaciół Nauk ${ }^{290}$ : Członkowie opracowywali rozprawy, odczytywali je na posiedzeniach, informowali o przebiegu pracy, zdawali sprawozdania $z$ wycieczek i wypraw naukowych. Przesylane prace do oceny rozpatrywano na specjalnych zebraniach odpowiednich komisji. Prowadzono korespondencje naukową i udzielano fachowych porad zainteresowanym problematyką $z$ dziedziny wchodzącej $w$ zakres prac poszczególnych wydziałów ${ }^{291}$. Zapraszano $z$ odczytami wybitnych uczonych $z$ Krakowa i Lwowa. Organizowano ogólnopolskie zjazdy naukowe ${ }^{292}$. Organem towarzystwa były „Roczniki...”, które ze względu na trudności wydawnicze nie wychodziły regularnie. W latach $1860-1873$ wydano 7 tomów ${ }^{293}$. Na honorowego prezesa wybrano arcybiskupa Przyłuskiego 294.

W prace towarzystwa wlączyli się kapłani archidiecezji gnieźnień-

288 Roczniki Towarzystwa Naukowego Krakowskiego z Uniwersytetem Jagiellońskim połączonego 3 (1847) 328, ogólnego Łbioru t. 18.

289 Rocz. TNK z U. J. połączonego 4 (1849) 14-53, ogólnego zbioru t. 19.

${ }^{290} \mathrm{Grot} Z$. i inni, Sto lat Poznańskiego Towarzystwa Przyjaciót Nauk, album, Poznań 1957, s. VI.

291 100 lat Poznańskiego Towarzystwa Przyjaciół Nauk i jego zbiorów, Poznań 1957, s. 17-18.

292 J a kó b cz y k W., Wielkopolska XIX wieku, s. 24.

${ }^{293} \mathrm{G}$ r ot Z. i inmi. Sto lat PTPN album, s. VII.

294 Przegl: Pozn. 25 (1858) 147-150. 
skiej i poznańskiej. Od samego początku należeli do niego: ks. Delert J. B., ks. Fabisz P., ks. Jabczyński J., ks. Janiszewski J., ks. Zienkiewicz J., ks. Ziętkiewicz W. ${ }^{295}$. Trzej pierwsi byli czlonkami wydzialu historyczno-moralnego. Na czoło wybili się: ks. Brzeziński A., ks. Likowski W., ks. Warmińs'ki I., ks. Kantak K., ks. Korytkowski J. i ks. Łukowski J.

Na posiedzeniu wydziału historyczno-moralnego w 1860 roku przedstawił ks. Jabczyński dwie prace: Wiadomość historyczna o mieczu starożytnym przechowywanym $w$ katedrze poznańskiej, którym wedlug podania ś. Piotr uciát ucho Malchusowi i O pierwotnem prawodawstwie kościelnym $w$ Polsce ${ }^{296}$. Ks. Brzeziński A. czytał Poglqd historyczny na sąownictwo $w$ sprawach malżenskich, Żywot Jarosiawa ze Skotnik Arcybiskupa gnieźnieńskiego 297 i Żywot ks. Kidaszewskiego ze szczególnym uwzględnieniem stanu oświaty $w$ pierwszej połowie dziewiętnastego wieku, jaki się uwydatnia mianowicie w ówczesnych zakładach naukowych ${ }^{298}$. Oprócz wymienionych rozpraw szereg prac o tematyce kanonistyeznej przygotowali świeccy czlonkowie towarzystwa. Zachęcony przez ks. Jabczyńskiego, lekarz poznański dr L. Gąsiorowski przygotowal rozprawę $O$ kanonikacie medycznym $w$ Gnieźnie $i$ Poznaniu ${ }^{299}$. Znany historyk wielkopolski E. Kierski czytał Żywot prymasa Wojciecha Baranowskiego urodzonego r. $1540^{300}$. Prace wymienione nie wyczerpują szerokiego wachlarza zainteresowań, które rozbudzano na posiedzeniach. Rozprawy ogłaszano drukiem często pod nieco zmienionym tytułem, co świadczy że posiedzenia miały charakter raboczy. Uwagi i dyskusja pomagały do skonkretyzowania tematu i lepszego opracowania. Zarząd zwracal uwage na aktualne zagadnienia i zachęcał członków, by zajęli się nimi. Po śmierci arcybiskupa Przyłuskiego proszono ks. Jabczyńskiego, by opracował życiorys zmarłego. Ponieważ nie podjął tego zadania $z$ racji choraby, temat zlecono Emilowi Kierskiemu ${ }^{301}$.

Szereg kapłanów należących do Towarzystwa Przyjaciół Nauk Poznańskiego było obznajomionych $\mathrm{z}$ tego rodzaju praca $\mathrm{w}$ organizacjach studenckich. W 1836 roku powstało we Wroclawiu Torwarzystwo Literacko-Słowiańskie, którego prezesem i najgorliwszym opiekunem był prof. Purkynê, potem prof. Gitzler, Cybulski i Nehring. Prof. Gitzler wyjednal zatwierdzenie zrzeszenia, które otrzymało miano, „Akademickie Towarzystwo Literacko-Slowiańskie". Celem towarzystwa było dokładniejsze zapoznanie się członków z językami, literaturą, hi-

$\begin{array}{lllll}295 & \text { Rocz. PTPN } 1 & (1860) & 615 . \\ \text { 296 } & \text { Rocz. PTPN } 1 & (1860) & 588 . \\ \text { 297 } & \text { Rocz. PTPN } 2(1863) & 779 . \\ 298 & \text { Rocz. PTPN } 3(1865) & 614 . \\ \text { 299 } & \text { Rocz. PTPN } 1(1860) & 588 . \\ 300 & \text { Rocz. PTPN } 3(1865) & 614 . \\ 301 & \text { Rocz. PTPN } 4(1866) & 557 .\end{array}$ 
storią i prawem ludów słowiańskich. Realizowano to przez rozmowy, pisanie rozpraw i dyskusje ${ }^{302}$. Mimo niemożliwości drukowania, powstały liczne prace pozaliterackie dotyczące oświaty, religii i zagadnień ogólnych ${ }^{303}$.

Czynnie uczestniczyli $w$ pracach towarzystwa studenci teologii pochodzący z archidiecezji gnieźnieńskiej i poznańskiej. Jan Jamiszewski w 1840 roku wygłosil 3 referaty. W styczniu mówil na temat Czy Naruszewicza „Historia” jest dla narodu tym, czym być powinna, a w marcu i grudniu tegoż roku omawial zagadnienie wiary i wiedzy. Przeciw filozofii Hegla wystąpil Jan Respądek w referacie pt. Poezja powinna naśladować naturę ${ }^{304}$. Przedstawione tematy obok wartości naukowej miały znaczenie światopoglądowe. $Z$ zagadnień historycznoprawnych, których część drukowana była w późniejszym czasie w czasopismach poznańskich, Tomicki Symforion przygotował $w$ ramach dzialalności towarzystwa rozprawę $O$ wprowadzeniu chrześcijaństwa do Stowian ${ }^{305}$, Tafelski Ludwik O kolędowaniu, zwyczaju słowiańskim, Chłostowski Józef Historia rozwijania się prawa, Gromadziński Maksymilian O prawie cywilnym $w$ Polsce, Lewandowski Julian Państwo ma się zasadzać na narodowości. Na tematyke mial wplyw prof. Ryszard Roepell, który po odjeściu Purkyniego byl nieoficjalnym opiekunem Towarzystwa Literacko-Słowiańskiego. Sam profesor zajmowal się statutem wiślickim. Pod jego kierunkiem Lipski Józef opracowal zagadinienje De iure decimarum ecclesiasticarum in Polonia animadversione historicae, $O$ dziesięcinach $w$ Polsce od zaprowadzenia chrześcijaństwa az do Kazimierza Wielkiego, Plebański Józef prace seminaryjną $O$ fundacji biskupstwo poznańskiego $i$ wzniesieniu metropolii gnieźnieńskiej oraz o założeniu biskupstwa krakowskiego czytal na zebraniu Towarzystwa Literacko-Słowiańskiego. Referowano rownież zagadnienie zaprowadzenia chrześcijaństwa $w$ Polsce. Zastanawiano sie na zebraniu „Dlaczego protestantyzm nie przyjął się $w$ Polsce" i omawiano losy protestantyzmu w Polsce od Zygmunta I aż do śmierci Zygmunta III ${ }^{\mathbf{3 0 6}}$.

Studenci polscy prawie we wszystkich ośrodkach uniwersyteckich zrzeszali się, aby krzepić ducha narodowego i pogłębiać wiadomości. W Berlinie grupa młoủieży akademickiej skupiała się przy Janie Koźmianie ${ }^{307}$, we Fryburgu Badeńskim przy Feliksie Kozłowskim ${ }^{303}$, a $w$ Monasterze $w$ drugiej połowie XIX wieku działało Towarzystwo Teologiczno-Literackie, które posiadało swoją bibliotekę i czytelnie.

${ }_{302} \mathrm{~K}$ a r b ow i a k A., Mrodziej Pol. akad. za granica, s. 23-25.

303 A.ch ir e m owicz E., Zabski T., Tow. lit.-stow., s. 62.

s04 A c hrem ow ic z E., Zabski T., Tow. lit.-stow., s. 62, 99.

305 Praca została opublikowana w Gazecie Kośc. +(1847) 81 ns.

308 A c hremow icz E., Żabsżi T., Tow. lit.-stow., s. 165.

307 Likow ski E., Mowa żałobna na cześć ś. $p$. $x$ Jana Koźmiana,

s. 13; K a r w owski S., Historia Wielkiego Księstwa Poznańskiego,

t. 1, Poznań 1918, s. 329 . 
Prezesem towarzystwa w latach $1868-1869$ był ks. Władysław Chotkowski. $\mathrm{Na}$ posiedzeniach zajmowano sie zagadnieniami teologii, historii Kościoła i literatury polskiej ${ }^{309}$. W ramach teologii i historii Kościoła zajmowano się zagadnieniami kanonistycznymi.

Jak zdobycie wiedzy $w$ okresie studiów uzależnione jest przede w.szystkim od kwalifikacji profesora i jasnego wykładu, tak poglębienie wiadomości uwarunkowane jest możliwością korzystania $z$ archiwów i bibliotek. Na skutek rozbiorów, naród polski poniósł olbrzymie straty przez zniszczenie lub wywiezienie cennych zabytków piśmiennictwa. Bogate zbiory klasztorów wielkopolskich po konfiskacie zakonów przewiezione zostały do biblioteki królewskiej i biblioteki uniwersyteckiej w Berlinie. Jedynie drobna część pozostala w kraju ${ }^{310}$.

Biblioteka Seminarium Duchownego w Poznaniu liczyla w 1761 roku 96 książek. Byla raczej pođręczną biblioteką profesorów. Powiększona. została w 1781 roku przez włączenie księgozbioru ,kościoła poznańskiego", czyli biblioteki kapitulnej. Po reorganizacji seminarium duchownego biblioteką zajmowali się $w$ charakterze dyrektorów profesorowie seminarium: ks. Alzog, Pohl i Uedink ${ }^{311}$. Biblioteka była w polowie XIX wieku uporządkowana. Pracował przy tym prof. Uedink. Sporządzony przez niego spis nie odpowiadal wymogom. Gdy prowizorat w 1851 roku nakazal uporządkowanie biblioteki, rektor Janiszewski przedstawil trudności lokalowe i personalne. Pomieszczenie było zbyt małe, a słabe stropy nie pozwalały na obciążenie nadmierna ilością książek. Czas pracy nad uporządkowaniem biblioteki przez jednego czlowieka i przy pomocy kleryków obliczył na półtora roku ${ }^{\mathbf{3 1 2}}$. Można stąd wnioskować, że księgozbiór seminaryjny $w$ polowie XIX wieku był dość zasobny.

Archiwum biskupstwa poznańskiego posiadało przeważnie dokumenty majątkowe zawierające najczęściej nadania i przywileje. bo o te akta rządcy najbardziej dbali. Od 1793 roku rozpoczęto prowadzić registrature akt dla poszczególnych spraw czy kościolów. $Z$ akt średniowiecznych ocalało bardzo mało. Początkowo układano akta $w$ porządku chronologicznym, dopiero arcybiskup Dunin w roku 1831 zaprowadził układ systematyczny, a jego następca arcybiskup Przyłuski pilnowal, by rozpoczęte dzieło dalej kontynuowano ${ }^{313}$.

Seminarium duchowne w Gnieźnie prowadzone przed 1835 rokiem przez księży misjonarzy nie posiadało zasobnej biblioteki. Chociaż naj-

s. 3 .

308 Brzeziński A., Mowa żałobna na pogrzebie $x$ Kozlowskiego, ${ }^{309} \mathrm{~K}$ a r bow i a k A., Miodziez Pol. akad. za granica, s. 80.

310 Grycz J. Gryczow a A., Historia ksiqżki $i$ bibliotek $w$ zarysie, Warszawa 1959 , s. 137.

311 Ma jkowski E., Biblioteka archidiecezjalna. W: Biblioteki wielkopolskie i pomorskie, red. Wierczyński S., Poznań 1929, s. 6-7. 312 AAP, Pismo z dnia 28 IV 1851, SD 12

313 N o w a cki J., Archidiecezja poznańska, s. 172. 
prawdopodobniej istniał jakiś mały zbiór, to nie nazywano go biblioteką ${ }^{314}$. Fakt stworzenia studium praktycznego $w$ Gnieźnie nie zrodził pilnej potrzeby zgromadzenia poważniejszego księgozbioru $\mathbf{z}$ dziedziny kanonistycznej. Nie sprzyjała temu poczatkowo mała liczba profesorów i wychowanków oraz nastawienie $z$ jakim przybywali tu klerycy. Zbierano więc dzieła do użytku praktycznego, przeważnie z dziedziny kaznodziejskiej. W 1840 roku do Gniezna przewieziono część biblioteki klasztornej benedyktynów w Lubiniu ${ }^{315}$.

Najcenniejszym księgozbiorem w archidiecezji gnieźnieńskiej była biblioteka kapitulna w Gnieźnie. Istniała już w XII wieku. Jej stare zbiory pochodziły przeważnie $z$ darowizn biskupów i kanoników. Jan II Gerbicz biskup poznański (1286-1297) podarował kodeks pergaminowy Dekretałów Grzegorza IX ${ }^{316}$, Piotr z Zawichcsta mistrz dekretów przekazał w 1414 roku 13 woluminów treści prawniczej. Po zmarłym Mikołaju Kickim ( $†$ 1429) otrzymano w 1435 roku 16 woluminów prawniczych. Biskup Tomasz Strzempiński w 1461 roku podarowal 22 woluminy $z$ dziedziny prawniczej i homiletycznej. Całą bibliotekę prawniczą składająca się z $37 \mathrm{ksiąg} \mathrm{zapisem} \mathrm{testamentowym} \mathrm{oddał} \mathrm{kapi-}$ tule gnieźnieńskiej 10 XI 1497 roku kanonik Jakub Boksica. Po zmarłym w 1615 roku prymasie Wojciechu Baranowskim do księgozbioru kapitulnego dostało się kilkaset tomów cennych dzieł. Arcybiskup Leszczyński (1658-1660) przekazal bibliotece 37 tomów Conciliorum generalium et provincialium collectio regia, Paryż 1644. W XIX wieku 1000 tomów oddał do biblioteki Wojciech Anzelm Brodziszewski ( $†$ 1866) biskup pomocniczy gnieźnieński. Całą swą bibliotekę przekazal kanonik Jan Piotr Zienkiewicz ( $\dagger$ 1874), kanonik Maciej Dorszewski ( $\dagger$ 1880) i notariusz kapitulny Antoni Dyament ( $\dagger$ 1885). Zbiór ostatniego nie był wielki, ale zawieral kilkanaście inkunabułów i kilkadziesiąt rzadkich druków polskich z XVI i XVII wieku ${ }^{317}$. Już z wyżej podanego wykazu, aczkolwiek niepelnego, widać że biblioteka kapituły gnieźnieńskiej była poważnym księgozbiorem kościelnym. Obok dzieł teologicznych i zbiorów kazań posiadała bardzo dużo pozycji kanonistycznych. Można wyciągnąć wniosek, że w tej dziedzinic była najbardziej zasobną na terenie całej Wielkopolski. W pierwszych dziesiątkach XIX stulecia nie była należycie uporządkowana. Zająl się tą sprawą bardzo gorliwie ks. Jan Piotr Zienkiewicz ${ }^{318}$, co ułatwilo znacznie korzystanie z zasobów bibliotecznych.

${ }^{314} \mathrm{H}$ oz a kow ski W., Reorganizacja seminarium, s. 239.

s15 Ostrowski J., Biblioteka klasztoru Benedyktynów w Lubiniu. W: Biblioteki wielkopolskie i pomorskie, red. Wierczyński S., Poznań 1929 , s. 176.

${ }_{316}$ Trzciński T., Sredniowieczne reqkopisy biblioteki kapitulnej $w$ Gnieźnie, Rocz. PTPN 35 (1909) 208.

317 Formanowicz L., Biblioteka kapitulna $w$ Gnieznie. W: Biblioteki wielkopolskie i pomorskie, red. Wierczyński S., Poznań 1929, s. $154-158$.

318 Kuryer Poznański z dnia 26 I 1874. 
Do mniejszych bibliotek poklasztornych rie docierało państwo czy upoważnieni przez arcybiskupa profesorowie seminarium $w$ celu przejęcia ich zbiorów. Stały się one pod'stawą bibliotek dekanalnych, które $z$ polecenia arcybiskupa Dunina ${ }^{319}$ organizowano $w$ XIX wieku na terenie archidiecezji gnieźnieńskiej j poznańskiej. Powstała wtedy biblioteka dekanalna w Białczu, Biezdrowie, Borku, Czarnkowie, Grabowie nad Prosną, Koźminie, Krobi, Krotoszynie, Mą̨znikach, Nowym Mieście, Osiecznej, Trzcinicy i innych miejscowościach. Następcy arcybiskupa Dunina interesowali się stanem bibliotek dekanalnych. W ramach wizytacji kanomicznej oglądali pomieszczenia $w$ których znaj• dował sie księgozbiór dekanalny, a $\mathrm{w}$ razie dostrzeżenia niedociągnięc wydawali odpowiednie polecenia. W 1871 roku oglądał biblioteke dekanalną $w$ Trzcinicy ks. arcybiskup Ledóchowski. Zbiór znajdowal się $\mathrm{W}$ salce przy kościele ${ }^{320}$.

Duchowieństwo archidiecezji gnieźnieńskiej i poznańskiej oprócz możliwości korzystania $\mathrm{z}$ wymienionych już archiwów i bibliotek oraz własnych zbiorów, miało dostęp do bibliotek publicznych i prywatnych. Biblioteki powstawały $z$ inicjatywy prywatnych fundatorów, którzy w trosce o zachowanie języka i narodowej świadomości gromadzili rękopisy oraz pozycje drukowane i udostępniali je publiczności.

Pierwszą bibliotekę publiczną w Poznaniu zalożył hrabia Edward Raczyński. Zaczątek stanowił księgozbiór oddziedziczony po przodkach przechowywany w zamku wyszyńskim. Po kasacie klasztorów nabyl fundator część archiwum i biblioteki cystersów w Paradyżu oraz 'szczątki innych bibliotek wielkopolskich klasztorów. Najwięcej książek naplynęlo $z$ biblioteki uniwersytetu wrocławskiego i berlińskiego, skąd przekazywano dublety. W 1832 roku biblioteka posiadała okolo 20000 tomów ${ }^{321}$, a w 1854 roku osiągnęla liczbę 30000 tomów ${ }^{822}$. Korzystanie ze zbioru znacznie ułatwił wydrukowany w 1865 roku katalog alfabetyczny. W odleglym okolo $20 \mathrm{~km}$ od Poznania Kórniku gromadzil cenne zbiory Adam Tytus Działyński. Znalazły sie tam przede wszystkim polskie dziela XVI wieku z historii, poezji, przyrody i teologii. Do polowy XIX stulecia zbiór posiadal ponad 10000 pozycji. W 1868 roku w Kórniku było 111 rękopisów z teologii, 336 z historii, 296 z literatury i 147 z prawa ${ }^{323}$. Idea gromadzenia starych pomników piśmiennịctwa i nabywania bieżących pozycji przenikała wielu wlaścicieli majątków na terenie Wielkopolski. Niemal w każdym powiecie

319 M a jk ow ski E., Biblioteka archidiecezjalna, s. 9.

320 Tyg. Katol, 12 (1871) 291.

${ }^{321}$ W o jtk ow sk i A., Biblioteka Raczyńskich (1829-1929). W: Biblioteki wielkopolskie i pomorskie, red. Wierczyński S., Poznań 1929, s. 36 .

D. Jerzy, W sprawie Biblioteki Raczyńskich, Przegląd graficzny $2(1920-1921) 82$.

${ }_{323}$ B od niak S., Biblioteka Kórnicka. W: Biblioteki wielkopolskie i pomorskie, red. Wierczyński S., Poznań 1929, s. 201. 
znalazl się mecenas nauki, którego ambicją bylo posiadać zasobny i wartościowy księgozbiór. Równocześnie $z$ założeniem Towarzy.stwa Przyjaciól Nauk Poznańskiego, powstała myśl stworzenia wlasnej biblioteki. Zalążek stanowiły książki przekazane przez osaby prywatne. W 1862 roku biblioteka liczyła 4000 tomów, w 1864 roku wzrosła do 5000 tomów, a w 1869 roku osiągnęla już blisko 8000 tomów. Mimo walki kulturalnej biblioteka rozwijała się $w$ dużym tempie. W roku 1880 osiągnęła 50000 tomów ${ }^{324}$.

Kaplani pracujący w Poznaniu mogli czerpać $z$ bardzo bogatych zbiorów tam zgromadzonych, a inni z bibliotek prywatnych rozsianych $\mathrm{w}$ terenie i ze zbiorów dekanalnych. W pierwszej połowie XIX wieku zdarzało się, że jeden kapłan musiał obsłużyć nieraz 2 a nawet 3 parafie. Miejscowości dzieliła często duża odległość, a środkiem komunikacji była furmanka. Mimo to była spora grupa księży, któræ wśród ciężkich obowiązków duszpasterskich zajmowała się nauką. Mniej obchodziły kapłanów tamtych czasów sprawy materialnego utrzymania kościołów. Tym zajmował się patron. Dużo jednak angażowało administrowanie majątkiem beneficjalnym. Wśród tygodnia kapłani każdego dnia mogli wygospodarować kilka godzin (2-3) na lekturę. Dysponując takim czasem najchętniej sięgali po interesujące czasopisma.

Pierwszym czasopismem kościelnym wydawanym w Pozmaniu było Archiwum Teologiczne ${ }^{325}$. Wychodzilo od początku 1836 roku do konca 1837 roku, jako kwartalnik obejmujący 132 strony $w$ formacie $20 \times 13 \mathrm{~cm}$. Redaktorem był ks. Jan Nepomucen Jabczyński. Liczba prenumeratorów byla dość duża, gdy porównamy ją z ilością kapłanów pracujących $w$ tym czasie $w$ archidiecezji gnieźnieńskiej i poznańskiej ${ }^{326}$. Swiadczy to o dążeniu duchowieństwa do pogłębiania wiedzy zdobytej $w$ seminarium i o powadze jaką cieszył się redaktor. W archidiecezji poznańskiej otrzymywalo Archiwum Teologiczne 349 osób, a w archidiecezji gnieźnieńskiej 101. Sam tytuł wskazywał na charakter historyczny pisma (archiwum), a wyksztalcenie i zamiłowanie prawnicze redaktora zadecydowało o dużej ilości artykułow historyczno-prawnych. Czasopismo pelniło też rolę dobrego informatora o publikacjach naukowych z teologii dogmatycznej, moralnej, pasterskiej, prawa kanonicznego, katechetyki i homiletyki, liturgiki, historii Kościoła, patrystyki oraz archeologii, podając od czasu do czasu obok tytulu i ceny, charakterystykę dzieła. Za pomocą Archiwum Teologicznego arcybiskup Dunin ogłosił dwa konkursy naukowe na temat

324 Dobrzyń ska-Rybicka L., Biblioteka Tow. Przyjaciót Nauk, W: Biblioteki wielkopolskie i pomorskie, red. Wierczyński S., Poznań 1929 , s. 47.

${ }^{325} \mathrm{~K}$ a r wo wski S., Historia W. Ks. Poznańskiego, t. 1, s. 252.

${ }^{326} \mathrm{~W} 1844$ roku w archidierezji gnieźnieńskiej pracowało 214 kaplanów, a w poznańskiej 381 (Gazeta Kośc. 2 (1844) 23-24). 
kongregacji dekanalnych i opieki duszpasterzy nad szkolami parafialnymi.

Wystąpienie ks. Jana Czerskiego oraz błędy religijne szerzone przez dziennikarzy i pisarzy zrodzily potrzebę naświetlenia zagadnień z pozycji zdrowej nauki katolidkiej. Zajął się tym ks. Ludwik Urbanowicz, który od stycznia 1845 roku do końca 1846 roku redagował miesięcznik Obrona prawdy ${ }^{327}$. W drugim roku czasopismo ukazywało sie nieregularnie. Poszczególne poszyty składaly się z $50-82$ stron $w$ formacie $20 \times 13 \mathrm{~cm}$. Duży udzial w wydawaniu mial Walenty Stefański. Pismo wychodzilo $\mathrm{z}$ jego drukarni, on finansowal nakład ${ }^{328} \mathrm{i}$ artykuły wysylano do jego księgarni. Odbiorcami „Obrony Prawdy” byli przeważnie duchowni pracujący na terenie Wielkiego Księstwa Poznańskiego. Za granicę przesylano niewielka liczbę egzemplarzy. Małe zainteresowanie pismem wykazali świeccy. Artykuły naukowe należy ocenić pozytywnie. Poruszały problematykę aktualną, a zwięzłość tresci pobudzała do czytania. $Z$ zagadnień prawnych zamieszczono artykuz "O prawie starozakonnym", gdzie autor w oparciu o Stary Testament podal przepisy prawa krajowego, prywatnego, kryminalnego, egzekucyjnego czyli sądownictwa wykonawczego i prawa policyjnego. Opublikowano część rozprawy ks. P. Fabisza pt. Obrona bezżeństwa kapłanów katolickich. Oprócz tego są krótkie artykuły: O przejściu Duchownych $z$ swojej do obcej Dyecezji, O godności Arcy-Biskupiej u nas, $O$ officyatach foralnych. O bractwach w kościele katolickim, $O$ posiadaniu, używaniu $i$ pozbywaniu dóbr duchownych, Pieczęcie kościelne i. Appelacye $w$ sadownictwie duchownem.

Artykuly kanonistyczne zamieszczane w Archiwum Teologicznym i Obronie Prawdy zajmowaly się przeważnie zagadnieniami lokalnymi. Sprawy Kościola powszechnego, a przede wszystkim z zakresu prawa publicznego podawał Przegląd Poznański, który wychodził od czerwca 1845 roku do grudnia 1864 roku. Początkowo ukazywal się w każdym miesiącu, a od połowy 1852 roku co 6 tygodni ${ }^{329}$. Posiadal format $25 \times 15 \mathrm{~cm}$. Każdy numer zawierał $108-120$ stron ${ }^{330}$. Głównym redaktorem był Jan Koźmian, który w Tuluzie uzyskal licencjat obojga praw. Czasopismo dostosowane bylo do poziomu warstwy najbandziej wyksztalconej. Przez artykuły i obiektywną krytykę literacką wywarło duży wplyw na piśmienictwo krajowe ${ }^{331}$. Zagadnieria kanonistyczne podawało $w$ formie artykułów, recenzji i publikacji wyjątków z dzitł

${ }^{327} \mathrm{Cza}$ rnowski S. J., Literatura perjodyczna $i$ jej rozwój, Kraków 1892, s. 347, błędnie podał tytuł pisma "Obraz Prawdy" zamiast "Obrona Prawdy" i rok wydawania 1844-1846 zamiast 1845-1846.

${ }^{328}$ Korczak B., Bibliografia prasy polskiej 1832-1864, Warszawa 1968 , s. 43.

${ }^{329}$ Przegl. Pozn. 38 (1865) s. I.

${ }^{330}$ Kor c zak B., Bibliografia prasy polskiej, s. 44.

331 Białecki A., Piśmiennictwo $w$ W. X. Poznańskiem od r. $1850 i$ charakter tegoż $w$ poprzedzajqcych latach, Teka Wileńska 6 (1858) 191. 
wydanych w Polsce i za granicą. Wiele miejsca poświęcono. władzy duchownej, posłannictwu Ojca św., sytuacji prawnej Kościola katodickiego w Prusach, Austrii, w Wielkim Księstwie Badeńskim i porl rządami rosyjskimi. Naświetlono kwestię rozwodów i prawodawstwa kościelnego względem tajnych towarzystw. Recenzje nowych publikacji dawały sposobnośc do stworzenia nbrazu stanu prawnego Kosciola w Polsce, stosunku papieża do Polski i podstaw prawnych doczesnej whadzy papieża.

Artykulów z dziedziny kanonistycznej objętościowo mniejszych niz w kwartalnikach i miesięcznikach, dostarczały duchowieństwu tygodniki. Ze względu jednak na częstsze docieranie do rąk czytelnißów, udegrały one nie mniejszą rolę niż poprzednie $w$ prywatnym poglebianiu wiedzy kanonistycznej. Dnia 31 III 1843 roku ukazal się pierwszy numer Gazety Kościelnej ${ }^{332}$, której redaktorem byl ks. Jan Nepomucen Jabczyński. Wychodziła $w$ każdy poniedzialek $w$ formacie $26 \times 21 \mathrm{~cm}$. Poszczególne numery obejmowały 8 stron. Byla pismem dla duchowieństwa i katolickiej inteligencji. Ze stanowiska zdrowej nauki naświetlała aktualine sprawy Kościoła katolickiego i podawała wiele materiału historyczno-prawnego czerpanego $\mathrm{z}$ archiwum archidiecezji poznańskiej. Wypadki, które zaszły w 1848 roku w Wielkopolsce spowodowały nieregularne wychodzenie Gazety Kościelnej. Ostatni numer ukazal się 13 VIII $1849^{333}$. Po krótkiej przerwie ks. Jabczyński wspólnie $z$ ks. Janiszewskim rozpoczęli wydawać Tygodnik Koscielny w takim charakterze, jaki posiadała „Gazeta Kościelna”. Czasopismo posiadalo 8 stron druku w formacie $27 \times 22 \mathrm{~cm}{ }^{334}$. Redaktorzy zamierzali zająć się aktualną sprawą: stosunku Kościoła do państwa, związku Kościoła ze szkołą, wolności wyznania, synodów diecezjalnych, wyłształcenia duchowieństwa, udziału świeckich w sprawach Kościoła, dziesięcin i dobroczynności chrześcijańskiej. Wydawa.nie tego tygodnika, zamknięto na 26 numerze, ze względu na truđności wydawnicze. Wychodzil ad 3 I do 27 VI 1850 roku.

Zapotrzebowanie na katolicki tygodnik rozumial arcybiskup Przyłuski. Wprawdzie nie przyznawal wydawnictwom żadnej dotacji, ale skoro zaistniały odpowiednie warunki, zachęcił ks. Aleksego Prusinowskiego do wydawania Tygodnilka Katolickiego ${ }^{235}$. Czasopismo wychodziło od 6 IV 1860 roku do 7 II 1874 roku w formacie $30 \times 22 \mathrm{~cm}$. Poszczególne numery posiadały najmniej 8 stron druku. Od czasu do czasu objętość pisma zwiększano. Zamierzano zamieszczać w nim roz-

352 Była nowym czasopismem, a nie kontynuacją „Archiwum Teologicznego" jak błędnie podaje Korczak B., Bibliografia prasy polskiej, s. 43 .

${ }^{335} \mathrm{~J}$ a r ochowski K., Literatura poznańska pierwszej polowy bieżqcego stulecia, P.oznań 1880 , s. 112 , błędnie podaje czas wydawania "Gazety Kościelnej" 1842-1847 zamiast 1843-1849.

s34 Ko r c zak B., Bibliografia prasy polskiej, s. 48.

395 Tyg. Katol. 12 (1871) 1. 
porządzenia Stolicy Apostolskiej, arcybiskupa, konsystorza gnieźnieńskiego i poznańskiego, arcybiskupów i biskupów polskich oraz innych biskupów, rozprawy $\mathrm{z}$ historii Kościoła, teologii moralnej, pasterskiej, prawa kanonicznego i rubrycystyki, nadto wydarzenia z życia Kościoła, recenzje dziel, żywoty zasłużonych lữzi, wskazówki moralne i pedagogiczne. Materiał byl tak obszerny, że już w 1860 roku rozpoczęto wydawanie dodatków zawierających rozporządzenia, listy pasterskie, okólniki i odezwy biskupów oraz konsystorzy, których przedmiotem były zasady wiary i karność kościelna. Dodatki wydawano w różnych odstępach czasu. Założycielem, pierwszym redaktorem, właścicielem i odipowiedzialnym wydawca był ks. Aleksy Prusinowski, a kontynuatorem ks, Józef Stagraczyński. Przez pewien czas pismo posiadalo kościelnego cenzora w osobie rektora seminarium ks. Walentego Wojciechowskiego ${ }^{336}$. Duchowiestwo archidiecezji gnieźnieńskiej i poznańskiej zaraz po ukazaniu się pierwszych numerów Tygodnika Katolickiego w znacznej liczbie wpłaciło prenumerate. W listopadzie 1860 roku ilość prenumeratorów osiągnęła cyfrę $400^{337}$, z czego około 100 mieszkało poza granicami Wielkiego Księstwa Poznańskiego. Juź w maju 1861 roku było 672 prenumeratorów, a w momencie największego rozkwitu tygodnik mial okolo 1000 odbiorców ${ }^{338}$. Profil tygodnika zatwierdzony przez arcybiskupa Przyluskiego ${ }^{339}$ zostal utrzymany. Redakcja pomogła w wydaniu I tomu Decretales Summorum Pontificum pro Regno Poloniae et constitutiones synodorum provincialium et dieocesanarum Regni eiusdem ad summam collectae, Posnaniae 1869, przez ogloszenie i kilkakrotne wezwania do nabycia, by $\mathrm{W}$ ten sposób umożliwić pokrycie kosztów druku. W ostatnich numerach wprowadzono specjalny dzial zatytulowany Kwestye kanoniczne, który przygotowywał ks. J. Eukowski. Przyjęto tu formę pytań i odpowiedzi popartych dekretami i stanowiskiem prawników.

Czasopisma katolickie dawały duchowieństwu archidiecezji gnieźnieńskiej i poznańskiej szerokie możliwości prywatnego pogłębiania wiedzy kanonistycznej. Zawierały wiele materiału, a redaktorzy nieustannie wzywali kapłanów do wspólpracy. Pogłębianiu wiedzy i twórczości sprzyjała naukowa atmosfera środowiska poznańskiego. Czasopisma religijno-teologiczne rozwinęly się tutaj bardziej niz $w$ dużych miastach na terenie zaboru rosyjskiego czy austriackiego ${ }^{340}$. Poza drobnymi wyjątkami, kapłani archidiecezji gnieźnieńskiej i poznańskiej pogłębiali wiedzę, by lepiej spełnić swe posłannictwo i zaspokoić wrodzoną szlachetną dążność poznania prawdy.

s36 A.AP, Pismo ks. J. Brzezińskjego wikariusza kapitulnego z dnia 24 VIII 1864, OA VI 246.

${ }^{337}$ Gr rot Z., Ks. Aleksy Prusinowski, Poznań 1935, s. 67.

338 Tyg. Katol. 13 (1872) 676.

339 AA.P, OA VI 246.

${ }^{340} \mathrm{Cz}$ arnowski S. J., Literatura perjodyczna, s. 347 . 


\section{Zakończenie}

Nauka prawa kanonicznego znalazła $w$ XIX wieku $w$ archidiecezji gnieźnieńskiej i poznańskiej właściwe miejsce i dobre zrozumienie. Doceniali jej wartość arcybiskupi Dunin i Przyłuski. Sami posiadali. w tej dziedzinie wysoikie kwalifikaoje. Zreorganizowane seminarium teoretyczne w Poznaniu i praktyczne w Gnieźnie dawało stosowne przygotowanie intelektualne $i$ moralne do pracy duszpasterskiej. Podczas czteroletnich studiów kandydaci do kaplaństwa poznawali: ogólne zasady stanowiące fundament prawa, znaczenie przepisów prawnych, wzajemny związek łączący poszczególne przepisy prawne, okoliczności towarzyszące powstawaniu prawa, cel prawa $i$ historyczny rozwój poszczególnych instytutów prawnych. Z notatek wykładów, które zachowały się $w$ Archidiecezjalnym Archiwum $w$ Poznaniu i $z$. tematów opracowanych ${ }^{-}$na egzaminie pisemnym widać, że profesorowie obok wyjaśnienia norm prawnych zapoznawali kleryków ze źródłami prawa powszechnego i partykularnego oraz uwzględniali podbudowę teologiczną $w$ powiązaniu z tajemnicą Chrystusa i historią zbawienia. Wpajali zamiłowanie do zachowania porządku prawnego. Na pierwszym miejscu stawiano prawo boskie, a za nim kanoniczne i państwowe. Tam gdzie przepisy państwowe stały $w$ sprzeczności $z$ prawem kanonicznym, wskazywano na priorytet prawa kanoniczneg. Ks. Respądek, Brzeziński, Likowski, Kozłowski i Eukowski wykładali po polsku, co zmuszało ich do wyszukiwania odpowiednich terminow w języku ojczystym odpowiadających pojęciom prawnym. Prawo kanoniczne $w$ przygotowaniu kandydatów do kaplaństwa od 1835 roku stanowiło oddzielny przedmiot wykładowy. Stworzenie wspólnego seminarium dla obu archidięcezji umożliwiło dobór właściwie przygotowanych profesorów, którzy przeważnie zdobywali kwalifikacje na uniwersytetach niemieckich. Na poziom nauki wplynal dodatnio fakt, że $\mathrm{w}$ amawianym okresie przyjmowano do seminarium poznańsiziego młodzieńców ze świadectwem maturalnym.

Część maturzystów z Wielkopolski wyjeżdżała na uniwersytety niemieckie, gdzie na wydziałach teologicznych oprócz wiadomości zdobywali metode pracy naukowej, która pomagała w prywatnym pogłabianiu wiedzy. Wolny czas od zajęć duszpasterskich wielu kapłanów przeznaczało nie tylko na ugruntowanie wiedzy zdobytej na wykladach, ale na uzasadnienie całego systemu prawnego Kościola przez dowody czerpane z filozofii i teologii. Sięgali po nowe książki i dostępne czasopisma naukowe. Na podstawie liczby prenumėratorów ,Tygodnika Katolickiego" można ustalić, że ponad $25 \%$ księży archidiecezji gnieźnieńskiej i poznańskiej dbało o pogłębianie wiedzy i wykorzystywało do tego wszelkie dostępne możliwości. Udzial w naukowysh. seminariach i towarzystwach mobilizował do pracy twórczej. Owocem tego sa liczne publikacje $z$ dziedziny prawa kościelnego przygoto- 
wane przez kapłanów archidiecezji gnieźnieńskiej i poznańskiej ${ }^{341}$ pracujących w administracji kościelnej, w seminariach duchownych i w duszpasterstwie. Najczęściej podejmowano tematy $z$ historii prawa polskiego, z prawa osobowego i rzeczowego. Zainteresowania historyczne wypływały $z$ ducha patriotycznego, by ukazać prawo narodu uciemiężonego przez zaborców, oraz założeń niemieckiej szkoły historyczno-prawnej propagowanych na uniwersytetach niemieckich $w$ XIX wieku.

Kapłani pracujący $w$ duszpasterstwie obok praktycznego stosowania prawa kanonicznego $w$ zakresie wewnętrznym, musieli znać kościelne prawo państwowe. Ustawodawstwo pruskie traktowało Kośció1 jako stowarzyszenie naturalne powstałe na mocy umowy dla wspólnego zaspokojenia potrzeb religijnych. Prawo kanoniczne jako obce prawo pomocnicze, od 1794 roku przestało być respektowane. Poniewaź ustawy prawa krajowego $w$ wielu wypadkach sprzeciwiały się zasadom prawa kanonicznego, kapłani często musieli występować w obronie wolności Kościoła na łamach czasopism, w izbach poselskich i przed trybunałami, które za działalność duszpasterską skazywały wielu gorliwych kapłanów na grzywnę lub na więzienie. Duchowieństwo zjednoczonych stolic arcybiskupich dobrze służyło Kościołowi i ojczyźnie, wykorzystując znajomość przepisów prawa kanonicznego.

341 Por. Bar J. R., Z ma rz W., Polska bibliografia prawa kanonicznego od wymalezienia druku do $1940 \quad r$., Lublin $1947-1960$. 


\section{Kanonistische Ausbildung der Geistlichen der Erzbistümer in Gniezno und Poznañ in den Jahren 1835-1873}

Infolge der Teilungen Polens in den Jahren 1772-1795 wurde fast das ganze Gebiet des Erzbistums in Gniezno und des Bistms in Poznań unter Regierung Preussens. Politische Verhältnisse und Rechtssituation der Kirche in Preussen haben ein dringendes Bedürfnis der Verhältnisregelung zwischen dem Staat und der Kirche hervorgerufen. Papst Pius der VII bestimmte mit der Bulle ,De salute animarum" am 25 III 1821 die Diözesengrenzen auf dem Gebiete Preussens. Das Bistum von Poznań wurde zum Erzbistum erhoben und ,aeque principaliter" mit dem Erzbistum von Gniezno der Personalunion verbunden. Kraft dieser Bulle konnte der Erzbischof den Entschluss fassen, ob es ein gemeinsames Seminar für zwei Erzbistümer errichten wird oder zwei voneinander unabhängige Seminare. Seit Ostern 1835 hatte man dreijähriges theoretisches Studium gegründet, nach dem die Kleriker einjähriges praktisches Studium in Gniezno fortsetzten. Seit dieser Zeit nahmen sich die Diözesenpriester der Kleruserziehung an.

Im November 1835 hatte der Erzbischof Dunin das Zwischenstatut vorbereitet und zwei Jahre später gab er „Ordinatio Seminarii Posnaniensis" heraus. Man benief vier Professoren: der Dogmatik, der Moraltheologie, dẹr Kirchengeschichte und des Kirchenrechts, und auch der Bibelerklärung. Latein war die obligatorische Unterrichtssprache. Die Professoren sollten 10 Vorträge und der Rektor 6 Vorträge wöchentlich durchführen. Die Unterrichtszal für einzelne Fächer wurde nicht bestimmt. Das Studienjahr begann am 15 Oktober und beendete am 15 August. Es wurde in zwei Semester geteilt. Das erste Semester (hibernum) dauerte von 15 Oktober bis zum Samstag vor dem Palmsonntag, und das zweite (aestivum) von Montag nach dem Weissen Sonntag bis zum 15 August. Jedes Semester endete mit der mündlichen. Prüfung. Drei Jahren folgte die schriftliche und mündliche Prüfung in der dogmatischen Theologie, Moraltheologie, Kirchengeschichte, im kanonischen Recht und in der Philosophie. Das erste Professorenkollegium rekrutierte sich im ganzem aus den Deutschen, die sukzessiv Poznań verliessen und auf ihre Stellen kamen Diözesenpriester aus Poznań und Gniezno.

Die Vorlesungen über kanonisches Recht im 1835 umfassten eine Stunde wöchentlich. Vom Jahre 1836 apferte man dem Recht fünf bis sechs Stunden in der Woche. Diese Vorlesungen waren für Kleriker des zweiten Semesters dritten Studienjahres vorgesehen. Professoren des kanonischen Rechts des Seminars in Poznań waren: A. Cappenberg, J. Alzog, J. F. Pohl, J. Jabczyński, L. Przyłuski, J. Respądek, A. Brzeziński und E. Likowski. Professor Respądek war zu dieser Arbeit am besten vorbereitet. Als Musterbuch diente die Arbeit von $\mathrm{F}$. Walter „Lehrbuch des Kirchenrechts aller christlichen Confessionen” erschienen in Bonn 1842. Nach damaligen Brauch hielten Brzeziński und Likowski auch die Vorlesungen uber Kirchengeschichte, was im grossen Grad das Durchdringen beider Disziplinen beeinflusste. Das grössere Gewicht legte man auf Traktaten, die mit der Pfarrarbeit verbunden waren, weil das Seminar eigentlich dafür vorbereitete.

In Gniezno man beschäftigte sich mit dem Problemem des kanonischen Rechts dann, als sie sich mit der Moraltheologie verbanden. Dort Erzbischof Przyłuski empfahl die Vorlesungszahl im Bereich des Messbuches und des Breviers zu reduzieren, um mehr Zeit dem Lesen des tridentischen Konzils und der Wiederholung der Moraltheologie, 
der dogmatischen Theologie und des Rechts zu opfern. Die Vorlesungen sollten fünf Stunden täglich dauern. Der Erzbischof Dunin empfahl das Buch von G. Rechberger „Enchiridion juris ecclesiastici austriaci" erschienen in Lincii 1819. Professor Kidaszewski beschäftigte sich mit der Arbeit von Simon Sobiech "Compendium theologiae moralis in usum confessariorum et examinandorum", Vratislaviae 1839, die viel Rechtsmateriall enthielt. Von den Professoren des Seminars von Gniezno, die Repetenten benannt wurden, verdienen hinsichtlich der Qualifikationen F. Kozłowski und J. Eukkowski erwähnt zu werden. Dank den Studien in Rom lernte J. Eukowski eine tiefere analytische Untersuchungen der gesetzlichen Vorschriften gerichtete $\mathrm{Me}$ thode kennen. Diese Methode unterschied isich vom der geschichtlichen Rechtsmethode, die damals an den deutschen Universitäten dominierte. Die analytische Methode uibte einen grossen Einfluss auf die Wissenschaftsentwicklung des kanonischen Rechts aus.

Preussische Behörden forderten von Professoren in Seminaren, in Gymnasien und auch von den, die sich um höhere Stellen in den Verwallungsbehörden bemühten, die Universitätsaubildung. DieRegierung blickte feindselig auf das Auslandsstudium. Die Grosspolnische Jugend studierte uiberwiegend an der Universität in Wroclaw. Das kanonische Recht trug man an der theologischen Fakultät und Rechtsfakultät vor. Eine gewisse Zeit übernahm niemand den Lehrstuhl für kanonisches Recht an der theologischen Fakultät. Studenten hörten damals Vorlesungen an der Rechtsfakultät. Der Wissenswert und Wissensbereich ist immer wieder von dem Vortragenden abhängig. Der erste Lehrer des kanonischen Rechts war M. Pekka, Autor des in polnischen Seminaren benutzten Buches. Der beste weltliche Kanonist war an der Universität in Wrocław im XIX Jahrhunderi L. A. Gitzler. In der ersten Hälfte des XIX Jahrhunderts erlebte die Universität in Wroclaw verschiedene Stürme, aber die Grosspolnische Jugeng nahm irrtümliche Ansichten nicht an.

Bis 1856 liess man den Klerikern die Studien in Poznań gelten und nach einem Jahr der Vorlesungbenutzung konnten die Studenten den akademischen Titel in München oder in Münster erwerben. Die Geistbehörden schickten den Klerikern auch nach Freiburg. Zwei berühmte Professoren Ernst de Moy und Georg Phillips waren mit der münchener Universität sehr eng verbunden. Sie übten einen grossen Einfluss auf die Entwicklung der Kanonistik aus nicht nur an eigener Universität sondern auch in anderen akademischen Zentren.

Junge Priester endeten die Studien mit der Priesterweihe und widmeten sich der Seelsorgenarbeit. Um Jurisdiktion und Pfarrenpfründe zu bekommen, sollten alle Priester die Prüfungen ablegen. Im XIX Jahrhundert entstanden in Polen kulturell-wissenschaftliche Vereinigungen, die die Wissensvertiefung ermöglichten. Diesen Vereinigungen gehörten viele Priester an. Wissenschaftliche Interessen und Rettungsideen der Schrifttumsdenkmäler trug zur Gründung vieler Bibliơtheken bei. Seit der Hälfte des XIX Jahrhunderts führte man dank der Bibliotheken rechtsgeschichtliche Untersuchungen. Die Pfarrer benutzten auch verschiedene wissenschaftlichen Zeitschriften: Archiwum Teologiczne, Obrona Prawdy, Gazeta Kościelna, Tygodnik Kościelny, Przegląd Poznański und Tygodnik Katolicki. Diese Zeitschriften enthielten umfassendes, kanonistisches Tatsachenmateriall. Auf diese Weise hoben die Geistlichen des Erzbistums in Gniezno und Poznań das Wissensniveau des Kirchenrechts. 